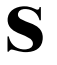

\section{SACRAMENTO STATE}

CSUS $6000 \mathrm{~J}$ Street, Sacramento, CA, 95819,

United States of America

Tel: (1) 9162786011

Fax: (1) 9162785199

Email: infodesk@csus.edu

Website: www.csus.edu

Contact: Timothy Hodson, Executive Director

Center for California Studies, CSU-Sacramento, California Legislature (CSUS) was founded in 1984. It is located on the capital campus of the California State University. Center for California Studies is a public service, educational support and applied research institute of CSUS. It is dedicated to promoting a better understanding of California's government, politics, people, cultures and history.

\section{California Senate Fellows}

Subjects: Public policy and politics.

Purpose: To expose people with diverse life experiences and backgrounds to the legislative process and provide research and other professional staff assistance to the Senate.

Eligibility: Open to candidates who have obtained a degree from a 4 year college or university.

Level of Study: Professional development

Type: Fellowships

Value: A monthly stipend of $\$ 2,627$ plus full health, vision and dental benefits

Length of Study: 11 months

Frequency: Annual

Country of Study: United States of America

No. of awards offered: 18

Application Procedure: Applicants can download the application

form from the website.

Closing Date: February 8th

Funding: Government

Additional Information: For further information please contact David Pacheco, the program director, at 9162785408 (Sacramento State), 9166514160 (Senate) or email to david.pacheco@sen.ca.gov.

For further information contact:

Tel: 9162786906

Email: calstudies@csus.edu

Website: www.csus.edu/calst/senate fellows program.html

\section{Jesse M. Unruh Assembly Fellowship Program}

Subjects: Public policy formation.

Purpose: To provide an opportunity for individuals of all ages, ethnic backgrounds and experiences to directly participate in the legislative process.

Eligibility: Applicants must have completed a Bachelor's degree by the end of Summer of the fellowship year. There are no preferred majors.

Level of Study: Professional development

Type: Fellowship

Value: US $\$ 1,972$ per month and medical, dental and vision benefits Length of Study: 11 months

Frequency: Annual

Study Establishment: Center for California Studies

Country of Study: United States of America

No. of awards offered: 18

Application Procedure: Applicants must download the complete application form from the website. Applicants must furnish academic, employment and activities data, unofficial transcripts from colleges attended, a personal statement, a policy statement on a specific topic contained in the application and 3 references.

Closing Date: February 22nd

Additional Information: Individuals with advanced degrees or those in mid-career are encouraged to apply.

For further information contact:

Tel: 9162786906

Email: calstudies@csus.edu

Website: www.csus.edu/calst/assembly_fellowship_program.html

\section{SAINT ANDREW'S SOCIETY OF THE STATE OF NEW YORK SCHOLARSHIPS, THE CARNEGIE TRUST FOR THE UNIVERSITIES OF SCOTLAND}

\author{
Andrew Carnegie House, Pittencrieff Street, \\ Dunfermline, Fife, KY12 8AW, Scotland \\ Tel: (44) 1383724990 \\ Fax: (44) 1383749799 \\ Email: admin@carnegie-trust.org \\ Website: www.carnegie-trust.org \\ Contact: Dr Patricia Krus
}

The Carnegie Trust for the Universities of Scotland administrates on behalf of the Saint Andrew's Society of the State of New York Scholarships to students of Scottish descent or birth for study at a university in the US, within a radius of 250 miles from New York City or the Washington DC area.

\section{Saint Andrew's Society of the State of New York Scholarship Fund}

Subjects: All subjects.

Purpose: To support advanced study exchanges between the US and Scotland.

Eligibility: Open to newly qualified graduates of a Scottish university or of Oxford or Cambridge. Candidates are required to have a Scottish background. The possession of an Honours degree is not essential.

Personality and other qualities will influence the selection.

Level of Study: Postgraduate

Type: Scholarship

Value: Up to US $\$ 20,000$ each to cover university tuition fees, room and board and transportation expenses

Length of Study: 1 academic year

Frequency: Annual

Study Establishment: A university within 250 miles of New York City or the Washington DC area

Country of Study: United States of America

No. of awards offered: 2

Application Procedure: Applicants must write for details. Each Scottish university will screen its own applicants and nominate one candidate to go forward to the final selection committee to be held in Edinburgh in April. Oxford and Cambridge applicants should submit applications to the trust.

Closing Date: January 25th

Funding: Private

No. of awards given last year: 2

No. of applicants last year: 7

Additional Information: Only in unusual circumstances will the Society consider other locations. Thereafter, the scholar is expected to spend a little time travelling in the US before returning to Scotland. Applications should be made via the principal of the university attended(ing) in the case of the Scottish universities.

\section{SAMUEL H KRESS FOUNDATION}

174 East 80th Street, New York, NY, 10075, United States of America Tel: (1) 2128614993 Fax: (1) 2126283146

Email: wyman.meers@kressfoundation.org Website: www.kressfoundation.org Contact: Wyman Meers, Program Administrator

The Samuel H. Kress Foundation, since its creation in 1929, has devoted its resources almost exclusively to programmes related to European art. The Foundation devotes its resources to advancing the history, conservation, and enjoyment of the vast heritage of European art, architecture, and archaeology.

\section{Conservation Fellowships}

Subjects: Specific areas of fine art conservation.

Purpose: To enable young American conservators to undertake postMA advanced internships.

Eligibility: Open to those who have completed their academic training in conservation. 
Level of Study: Postgraduate

Type: Fellowship

Value: US $\$ 32,000$

Frequency: Annual

Study Establishment: Appropriate institutions

Country of Study: United States of America

No. of awards offered: 9

Application Procedure: Application procedures and contact information available at www.kressfoundation.org. Program administered on Kress Foundation's behalf by the American Institute for Conservation. Forms and guidelines for submission available on website. Closing Date: January 22nd

Funding: Private

No. of awards given last year: 9

No. of applicants last year: Approx. $25-30$

Additional Information: Emphasis is on hands-on training. These grants are not for the completion of degree programmes. Enquiries should be directed to Wyman Meers.

\section{For further information contact:}

The Foundation of the American Institute for Conservation of Historic and Artistic Works, 1156 15th St, NW; Suite 320, Washington, DC 20005

Email: faicgrants@aic-faic.org

\section{Samuel H Kress Foundation 2-Year Research Fellowships at Foreign Institutions}

Subjects: Art history.

Purpose: To facilitate advanced dissertation research in association with a selected institute of art history in either Florence, Leiden,

London, Munich, Paris, and Rome.

Eligibility: Open to PhD candidates in the history of art for the completion of their dissertation research. Candidates must be citizens of the US or matriculated at an institution in the US.

Level of Study: Predoctorate

Type: Fellowship

Value: US $\$ 30,000$ per year

Length of Study: 2 years

Frequency: Annual

Study Establishment: One of a number of art historical institutes in Florence, Leiden, London, Munich, Paris, and Rome

No. of awards offered: 6

Application Procedure: Applicants must be nominated by their art history department. There is a limit of two applicant per department. The Foundation does not accept grant materials by fax. Each art history department can nominate two individuals; however, only one nominee per art history department for each host institutions.

Closing Date: November 30th

Funding: Private

No. of awards given last year: 6

No. of applicants last year: Approx. 50

Additional Information: Applications submitted directly to host institution with a copy to Kress Foundation. Contact information available at www.kressfoundation.org.

\section{Samuel H Kress Foundation Interpretive Fellowships at \\ Art Museums}

Subjects: Kress interpretive fellowships provide competitive grants to American art museums which sponsor supervised internships in art museum education, with preference given to projects that promote collaboration between art museum educators and curators and advancement of the appreciation of pre-modern European art history. Purpose: To encourage students to explore interpretive courses in art museums, whether as future museum educators or curators.

Eligibility: Open to individuals who have completed a degree (BA, MA or PhD) in art history, art education, studio art or museum studies and who are pursuing or contemplating graduate study or professional placement in these or related fields.

Level of Study: Graduate, Postgraduate

Type: Fellowships

Value: $\$ 30,000$

Length of Study: 9-12 months

Frequency: Annual

Country of Study: United States of America
Application Procedure: Application guidelines available at www. kressfoundation.org.

Closing Date: April 1st

Funding: Private

No. of awards given last year: 6

No. of applicants last year: 20

\section{THE SAN FRANCISCO FOUNDATION} (SFF)

One Embarcadero Center, Suite 1400, San Francisco, CA, 94111, United States of America

Tel: (1) 4157338500

Fax: (1) 4154772783

Email: info@sff.org

Website: www.sff.org

The San Francisco Foundation (SFF) is a leading agent of Bay Area philanthropy. They rank 7 th in grant making and assets among the nation's community foundations. They cultivate a family of donors who share a commitment to the Bay Area. They give millions of dollars a year to build on community assets, respond to community needs and elevate public awareness.

\section{Joseph Henry Jackson Literary Award}

Subjects: Fiction (novel or short stories), nonfiction, prose and poetry. Purpose: To support an author of an unpublished work in progress. Eligibility: Open to residents of northern California or Nevada for 3 consecutive years who are between 20 and 35 years of age.

Level of Study: Postgraduate

Type: Award

Value: US $\$ 2,000$

Frequency: Annual

Country of Study: United States of America

No. of awards offered: 2

Application Procedure: Applicants must submit manuscript of their unpublished work along with the application form, entry in a contest and stamped addressed envelope.

Closing Date: January 31st

Additional Information: In addition to the US $\$ 2,000$ cash award, winners will be invited to participate in a public reading at Intersection for the Arts and the winning manuscripts will be permanently housed at UC Berkeley's Bancroft Library. Please see the website for further details http://sff.org/programs/awards-programs/art-awards/iteraryawards/.

\section{Koshland Young Leader Awards}

Purpose: It recognizes the next generation of leadership in community. Koshland Young Leaders are strongly motivated to achieve despite facing multiple challenges, such as economic and family responsibilities.

Eligibility: San Francisco public high school juniors. The most competitive candidates have at least a 3.25 cumulative or continually improving GPA, are college-bound, and embrace a commitment to strengthening their families and communities despite facing formidable life challenges.

Level of Study: Postgraduate

Type: Award

Value: $\$ 7,000$

Length of Study: 2 years

Frequency: Every 2 years

Country of Study: United States of America

No. of awards offered: 8

Application Procedure: See the website.

Closing Date: January (four-part nomination process), check with the foundation

Contributor: San Francisco Foundation

Additional Information: Each winter, we invite teachers and counselors to nominate outstanding San Francisco public high school juniors for this award. If you have questions, please email or call Joshua Jones.

For further information contact:

Tel: 4157338587

Email: kyla@sff.org 


\section{SAN FRANCISCO STATE UNIVERSITY (SFSU)}

1600 Holloway Avenue, San Francisco, CA, 94132,

United States of America

Tel: (1) $4153382234 / 1111$

Fax: (1) 4153380942

Email: mritter@sfsu.edu

Website: www.sfsu.edu

San Francisco State University (SFSU) is one of the nation's leading public urban universities. SFSU helps create and maintain an environment for learning that promotes respect for and appreciation of scholarship, freedom, human diversity and the cultural mosaic of the City of San Francisco. SFSU also provides a higher education for residents of the region and state, as well as the nation and world.

\section{Robert Westwood Scholarship}

Subjects: Arts, health, science and social services.

Purpose: To assist SFSU students who are living with HIV and plan to make a contribution in any field to communities affected by HIV.

Level of Study: Postgraduate

Type: Scholarship

Value: US $\$ 1,000$

Frequency: Annual

Study Establishment: San Francisco State University

Country of Study: United States of America

No. of awards offered: 2

Application Procedure: Applicants must submit a copy of the most recent SFSU academic transcript, along with a brief, typed essay discussing plans to incorporate academic work and degree at SFSU with service in the HIV community or in the area of HIV prevention. Closing Date: May 7th

Additional Information: Applicants must submit a verification from the physician.

For further information contact:

Tel: 4153387339

Contact: Michael Ritter, Counseling and psychological services

\section{SANSKRITI PRATISHTHAN}

Head Office C-11 Qutab Institutional Area, New Delhi, 110-016, India Tel: (91) 112696 3226/2652 7077

$$
\text { Fax: (91) } 1126853383
$$

Email: fellowships@sanskritifoundation.org

Website: www.sanskritifoundation.org

Sanskriti Pratishthan is a non-profit organization that was established in 1978. Sanskriti Pratishthan perceives its role as that of a catalyst, in revitalizing cultural sensitivity in contemporary times.

\section{Kalakriti Fellowship in Indian Classical Dance \\ Subjects: Indian classical dance.}

Purpose: To encourage young artists to develop their potential and enhance their skills through intensive practice and/or incorporating different facets of their art.

Eligibility: Open to Indian nationals in the age group of 25-40. The candidates should have at least 10 years of initial training in Indian classical dance. The Fellows would be required to have given at least 2-3 solo performances to his/her credit in recognized forums.

Level of Study: Professional development

Type: Fellowships

Value: INR 50,000

Length of Study: 10 months

Frequency: Annual

Application Procedure: Applicants must send their 2-page curriculum vitae and a write up of approx. 500 words, explaining their project. Full postal and telephone contact details together with any email id should be submitted to facilitate contact. A few samples of previous work, project or performances should be submitted. The names and contact addresses/telephones of 2 referees should also be sent.

Closing Date: June 30th

Funding: Foundation
Additional Information: The candidate should not be holding any other fellowship or working on any other project at the same time. Please see the website for further details www.sanskritifoundation. org/Kalakriti-Fellowship.htm.

\section{Mani Mann Fellowship}

Subjects: Indian classical music

Purpose: To encourage promising young artists to advance in their field. This fellowship will enable the recipient to have the resources and time to dedicate to the art.

Eligibility: Open to Indian nationals in the age group of 25-40.

Applicants must hold a degree/diploma from a recognized university or institution in the field and/or the candidates should have at least

10 years of initial training in Indian classical music.

Level of Study: Professional development

Type: Fellowship

Value: INR 1,00,000

Length of Study: 3-12 months

Frequency: Annual

Country of Study: India

Application Procedure: Candidates should send their 2-page curriculum vitae and a write up of approximately 500 words explaining their project. Full postal and telephone contact details together with any email id should be submitted to facilitate contact. Few samples of previous work, project or performances should be submitted. The names and contact addresses/telephones of 2 referees should also be sent.

Closing Date: December 31st

Funding: Foundation

Additional Information: Please see the website for further details www.sanskritifoundation.org/Mani-Mann-Fellowship.htm.

\section{Prabha Dutt Fellowship in Journalism}

Subjects: Journalism.

Purpose: To encourage young mid-career women journalists to develop their potential by pursuing meaningful projects without having to work under the pressures of short deadlines.

Eligibility: Open to women candidates who are Indian nationals and between 25 and 40 years of age. It is exclusively for print journalists. Level of Study: Research

Type: Fellowships

Value: INR 1,00,000

Length of Study: 10 months

Frequency: Annual

Country of Study: India

Application Procedure: Applicants must send a two page curriculum vitae and a write-up of about 250-300 words explaining their project. Full postal and telephone contact details together with any email Id should be submitted to facilitate contact, 5 samples of work published should be submitted. The names and contact addresses/telephones of 2 referees should also be sent.

Closing Date: Applications are accepted round the year for the next year's fellowship

Funding: Foundation

Additional Information: The candidate should not be holding another fellowship or working on any other project at the same time. Please see the website for further details www.sanskritifoundation.org/ prabha-dutt-fellowship.htm.

\section{SAVOY FOUNDATION}

230 Foch Street, St Jean Sur Richelieu, Quebec, QC, J3B 2B2, Canada

$$
\text { Tel: (1) } 4503589779
$$$$
\text { Fax: (1) } 4503461045
$$

Email: epilepsy@savoy-foundation.ca

Website: www.savoy-foundation.ca

Contact: Vivian Downing, Assistant to Vice President/Secretary

The Savoy Foundation's main activity is to support and encourage research into epilepsy.

\section{Savoy Foundation Postdoctoral and Clinical Research Fellowships}

Subjects: Medical and behavioural science, as they relate to epilepsy. 
Purpose: To support a full-time research project in the field of epilepsy.

Eligibility: Candidates must be scientists or medical specialists with a PhD or MD.

Level of Study: Postdoctorate, Postgraduate, Research

Type: Research grant

Value: Canadian $\$ 30,000$

Length of Study: 1 year (non-renewable)

Frequency: Annual

Country of Study: Canada

No. of awards offered: Varies

Application Procedure: Applicants must contact the Foundation or visit the website for application forms and further information.

Closing Date: January 15th

Funding: Foundation, private

Contributor: The Savoy Foundation endowments

No. of awards given last year: Five Fellowships

No. of applicants last year: 26

\section{Savoy Foundation Research Grants}

Subjects: Medical and behavioural science, as they relate to epilepsy. Purpose: To support further research into epilepsy.

Eligibility: Only available to clinicians and established scientists. Level of Study: Postdoctorate, Postgraduate, Research

Type: Research grant

Value: Up to Canadian $\$ 25,000$

Frequency: Annual

Country of Study: Canada

No. of awards offered: Varies

Application Procedure: Applicants must contact the Foundation or visit the website for application forms and further information.

Closing Date: January 15th

Funding: Foundation, private

Contributor: The Savoy Foundation endowments

No. of awards given last year: 7 Research Grants

No. of applicants last year: 20

Additional Information: The grant is only available to Canadian citizens or for projects conducted in Canada.

\section{Savoy Foundation Studentships}

Subjects: Biomedicine, neurology and epileptology.

Purpose: To support training and research in a biomedical discipline, the health sciences or social sciences related to epilepsy.

Eligibility: Candidates must have a good university record, e.g. a $\mathrm{BSc}, \mathrm{MD}$ or equivalent diploma and have ensured that a qualified researcher affiliated to a university or hospital will supervise his or her work. Concomitant registration in a graduate programme is encouraged. The awards are available to Canadian citizens or for projects conducted in Canada.

Level of Study: Doctorate, Postgraduate, Predoctorate

Type: Studentship

Value: The stipend will be Canadian $\$ 15,000$ per year. An annual sum of Canadian $\$ 1,000$ will be allocated to the laboratory or institution as additional support for the research project. The student with the highest mark will receive the Van Gelder-Savoy award of an additional $\$ 1,500$. Also, in memory of the contribution made by Professor Laurent Descarries to the Savoy Foundation during his tenure as a member of the Research Committee, a new award of excellence has been created. The Descarries-Savoy award, in an amount of $\$ 1,500$, which will be granted to the student supported by the Foundation whom the committee decides has published the best paper during the year of the studentship

Length of Study: $1-4$ years

Frequency: Annual

Country of Study: Canada

No. of awards offered: Varies

Application Procedure: Applicants must contact the Foundation or visit the website for application forms and further information.

Closing Date: January 15th

Funding: Foundation, private

Contributor: The Savoy Foundation endowments

No. of awards given last year: 4 Studentships

No. of applicants last year: 17
SCHOOL OF ORIENTAL AND AFRICAN STUDIES (SOAS)

University of London, Thornhaugh Street, Russell Square, London, WC1H 0XG, England

Tel: (44) 02076372388

Fax: (44) 02070745089

Email: scholarships@soas.ac.uk

Website: www.soas.ac.uk

Contact: Miss Alicia Sales, Scholarships Officer, Registry

The School of Oriental and African Studies (SOAS) regards its role as advancing the knowledge and understanding of the cultures and societies of Asia and Africa and of the School's academic disciplines through high-quality teaching and research.

\section{A K S Postgraduate Bursaries}

Subjects: MA Korean studies, MA Korean literature, MPhil/PhD Korean Studies Research, MA History of Art.

Eligibility: Open to U.K./EU and overseas applicants. See the website for details.

Level of Study: Postgraduate

Type: Bursary

Value: Up to $£ 6,000$ towards tuition fees

Length of Study: 1 year

Frequency: Annual

Study Establishment: SOAS

Country of Study: United Kingdom

No. of awards offered: 2

Application Procedure: See website www.soas.ac.uk/scholarships for details.

Closing Date: May 24th

Funding: Private

Contributor: Academy of Korean Studies

No. of awards given last year: 1

Additional Information: If you have any questions about the bursary application, please contact the Scholarships Officer.

For further information contact:

Email: ak49@soas.ac.uk

Website: www.soas.ac.uk/registry/scholarships/aks-postgraduate-

bursary.html

Contact: Dr Anders Karlsson

\section{Ahmad Mustafa Abu-Hakima Scholarship}

Subjects: History of the modern Arab world.

Purpose: To offset tuition fees for a student taking a full-time master's programme which includes studying the history of the modern Arab world.

Eligibility: Open to U.K./EU and overseas applicants undertaking fulltime taught masters programme.

Level of Study: Postgraduate

Type: Scholarship

Value: $£ 2,000$

Length of Study: 1 year

Frequency: Annual

Study Establishment: SOAS

Country of Study: United Kingdom

No. of awards offered: 1

Application Procedure: See website www.soas.ac.uk/scholarships for details.

Closing Date: March 22nd

Funding: Private

No. of awards given last year: 1

Additional Information: Please see the website for further details www.soas.ac.uk/registry/scholarships/the-ahmad-mustafaabuhakima-bursary.html.

\section{AHRC Studentships}

Subjects: History, art, Asian languages and cultures, linguistics, middle east and African, music and religious studies.

Purpose: To support taught masters and research students.

Eligibility: Open to home and EU students.

Level of Study: Doctorate, Postgraduate

Type: Scholarship

Value: Maintenance plus approved tuition fees 
Study Establishment: SOAS

Country of Study: England

Application Procedure: Scholarship application should be made on the appropriate scholarship application form which is available for download.

Closing Date: Check the website: www.soas.ac.uk/

Funding: Government

Additional Information: There are two types of studentship awards a full studentship award for U.K. residents and a fees-only studentship award for EU residents. Please see the website for further details.

\section{Bernard Buckman Scholarship}

Subjects: MA in Chinese studies.

Purpose: The scholarship is intended to off-set the tuition fees at the

U.K./EU rate.

Eligibility: Open to those candidates who qualify to pay for home or European Union tuition fees. Applicants must possess a good

Honours Degree from a U.K. university or its equivalent

Level of Study: Postgraduate

Type: Scholarship

Value: Home or EU postgraduate fee

Length of Study: 1 year

Frequency: Annual

Study Establishment: SOAS

Country of Study: United Kingdom

No. of awards offered: 1

Application Procedure: Candidates can apply for this scholarship via the online scholarship application form.

Closing Date: March 22nd

Funding: Private

No. of awards given last year: 1

No. of applicants last year: 7

Additional Information: For enquiries, please contact Scholarships Officer.

For further information contact:

Tel: 0207074 5094/5091

Email: scholarships@soas.ac.uk

Website: www.soas.ac.uk/registry/scholarships/bernard-buckmanscholarship.html

\section{FELIX Scholarship}

Subjects: Oriental and African studies in archaeology, area studies economics, ethnomusicology, history, law, languages, linguistics, phonetics, politics, religious study, social anthropology and development studies.

Purpose: To support first class Indian students commencing a Master's programme or researching for a Doctoral degree at the School of Oriental and African Studies.

Eligibility: Open to applicants of any full-time taught Master's or MPhil/PhD programme, under 30 years of age, able to demonstrate financial need and would return to work in their home country after completion of studies.

Level of Study: Doctorate, Postgraduate

Type: Scholarship

Value: $£ 12,316$ per year plus tuition fees

Length of Study: $1-3$ years

Frequency: Annual

Study Establishment: SOAS

Country of Study: United Kingdom

No. of awards offered: 7

Application Procedure: A Felix Scholarship application form is available for download from the download box at the top right or can be obtained from Scholarships Officer.

Closing Date: January 31st

Funding: Private

Contributor: Felix Scholarship Trust

No. of awards given last year: 6

Additional Information: One award is made each year to a nonIndian student from a developing country who demonstrates academic excellence and financial need. Please see the website for further details www.soas.ac.uk/registry/scholarships/felix-scholarships.html.

\section{For further information contact:}

Tel: 0207074 5094/5091

Email: scholarships@soas.ac.uk
HSBC SOAS Scholarships

Subjects: Sinology or Chinese literature.

Purpose: To support U.K. or EU fee payers commencing a full-time master's course in Sinology or Chinese literature.

Eligibility: Applicants must possess or be about to complete a good honours degree, preferably first class, from a U.K. institution or overseas equivalent.

Level of Study: Postgraduate

Type: Scholarship

Value: $£ 16,650$ plus tuition fees at the home EU rate

Length of Study: 1 year

Frequency: Annual

Study Establishment: SOAS

Country of Study: United Kingdom

No. of awards offered: 2

Application Procedure: Candidates can apply for this scholarship via the online scholarship application form. For enquiries, please contact Scholarships Officer.

Closing Date: March 22nd

Funding: Trusts

Contributor: HSBC educational trust

No. of awards given last year: 2

For further information contact:

Tel: 0207074 5094/5091

Email: scholarships@soas.ac.uk

Website: www.soas.ac.uk/registry/scholarships/hsbc-soasscholarships.html

\section{Ouseley Memorial Scholarship}

Subjects: Any programme which involves research requires the use of any Middle Eastern or Asian language.

Purpose: To encourage the study of Arabic, Persian, Hindustani and other Oriental languages.

Eligibility: Open to U.K./EU and overseas applicants. Applicants must refer to the organization website for detailed information.

Level of Study: Doctorate, Postgraduate

Type: Scholarship

Value: $£ 6,000$ for 1 year only

Frequency: Annual

Study Establishment: SOAS

Country of Study: United Kingdom

No. of awards offered: 1

Application Procedure: See the website.

Closing Date: January 31st

Funding: Private

No. of awards given last year: 1

No. of applicants last year: 20

For further information contact:

Tel: 0207074 5094/5091

Email: scholarships@soas.ac.uk

Website: www.soas.ac.uk/registry/scholarships/ouseley-memorialscholarship.html

\section{SOAS Master's Scholarship}

Subjects: A variety of taught Master's programmes.

Purpose: To provide financial assistance to study for a full-time taught Master's programme.

Eligibility: Open to U.K./EU and overseas applicants who possess a First class Honours degree or equivalent.

Level of Study: Postgraduate

Type: Scholarship

Value: Approx. UK£15,000

Length of Study: 1 year, non-renewable

Frequency: Annual

Study Establishment: SOAS

Country of Study: United Kingdom

No. of awards offered: 11

Application Procedure: See the website.

Closing Date: March 22nd

Funding: Government

No. of awards given last year: 11

No. of applicants last year: 350 


\section{For further information contact:}

Email: scholarships@soas.ac.uk

Website: www.soas.ac.uk/registry/scholarships/soas-mastersscholarships_faculty-of-arts-humanities.html.

\section{SOAS Research Scholarship}

Subjects: The languages and cultures of Africa, East Asia, Near and Middle East, South Asia and South-East Asia, focusing on anthropology and sociology, art and archaeology, development studies, economics, ethnomusicology, financial and management studies, history, law, linguistics, political studies and the study of religions. Purpose: To support full-time research study at SOAS.

Eligibility: Applicants must U.K./EU and overseas and must possess or expect to be awarded a distinction in their Master's degree from a U.K. university or its equivalent.

Level of Study: Doctorate

Type: Scholarship

Value: $£ 12,790$

Length of Study: 3 years

Frequency: Annual

Study Establishment: SOAS

Country of Study: United Kingdom

No. of awards offered: 4

Application Procedure: Applicants must complete and submit an application form that can be downloaded from the website.

Closing Date: January 31st

Funding: Government

No. of awards given last year: 4

Additional Information: For enquiries, please contact Scholarships Officer.

For further information contact:

Email: scholarships@soas.ac.uk

Website: www.soas.ac.uk/registry/scholarships/soas-researchstudent-fellowship.html

\section{Sochon Foundation Scholarship}

Subjects: MA Korean studies, MA Korean literature, MPhil/PhD

Korean studies research and MA History of Art.

Purpose: For a student undertaking a full-time postgraduate

programme in Korean studies.

Eligibility: Open to U.K./EU and overseas applicants.

Level of Study: Postgraduate

Type: Scholarship

Value: UK£7,000

Length of Study: 1 year

Frequency: Annual

Study Establishment: SOAS

Country of Study: United Kingdom

Application Procedure: See the website.

Closing Date: May 24th

Funding: Foundation

No. of awards given last year: 1

For further information contact:

Email: scholarships@soas.ac.uk

Website: www.soas.ac.uk/registry/scholarships/sochon-foundationscholarship.html

\section{William Ross Murray Scholarship}

\section{Subjects: LLM.}

Purpose: To support a student of high academic achievement from a developing country unable to pay overseas tuition fees and attending the full-time LLM degree at SOAS.

Eligibility: Applicants from a developing country who must have a high level of academic achievements preferably first class, from a U.K. institution or overseas equivalent.

Level of Study: Postgraduate

Type: Scholarship

Value: Overseas tuition fees. Free accommodation at International

Student House and food vouchers

Length of Study: 1 year

Frequency: Annual

Study Establishment: SOAS
Country of Study: United Kingdom

No. of awards offered: 1

Application Procedure: See the website.

Closing Date: March 22nd

Funding: Foundation

No. of awards given last year: 1

For further information contact:

Email: scholarships@soas.ac.uk

Website: www.soas.ac.uk/registry/scholarships/william-ross-murrayscholarship.html

\section{SCIENCE AND ENGINEERING RESEARCH BOARD}

5 \& 5A, Lower Ground Floor, Vasant Square Mall, Sector-B, Pocket-5, Vasant Kunj, 110 070, India

Tel: (91) -11-40000398

Contact: Science and Engineering Research Board

The Science and Engineering Research Board (SERB) is a statutory body established through an Act of Parliament. Supporting basic research in emerging areas of science and engineering are the primary and distinctive mandate of the Board. The Board structure, with both financial and administrative powers vested in the Board, would enable quicker decisions on research issues, greatly improving thereby our responsiveness to the genuine needs of the research scientists and the S\&T system.

\section{J C Bose National Fellowship}

Subjects: All areas of science.

Purpose: The JC Bose fellowship is awarded to active scientists in recognition for their outstanding performance. The fellowship is scientist-specific and very selective.

Eligibility: The candidate should be an active scientist with a record of outstanding performance apparent from the award of SS Bhatnagar prize and or fellowship of science academies (including engineering, agriculture and medicine). The scientist should be in service at the time of nomination to this fellowship.

Level of Study: Research

Type: Fellowship

Value: The fellowship amount is Rs. 25,000 per month in addition to regular income. Research grant of Rs. 15.00 lakh per year. Overhead of Rs. 1.00 lakh per year to the host institute

Length of Study: 5 years

Additional Information: Selection of JC Bose Fellows will be made periodically (normally twice a year) by a Search-cum-Selection Committee specially constituted for the purpose, as per the broad guidelines of the fellowship scheme.

For further information contact:

Contact: Mr S.S. Kohli, Scientist G

\section{National Post Doctoral Fellowship (N-PDF)}

Purpose: The SERB-National Post Doctoral Fellowship (N-PDF) is aimed to identify motivated young researchers and provide them support for doing research in frontier areas of science and engineering. The fellows will work under a mentor, and it is hoped that this training will provide them a platform to develop as an independent researcher.

Eligibility: The applicant should be an Indian citizen. The applicant must have obtained Ph.D/M.D/M.S degree from a recognized University.

Type: Fellowship

Value: Fellowship: Rs. 55,000 per month (consolidated) and Rs. 35,000 per month for candidates who have submitted the thesis but degree not awarded. Research Grant: Rs. 2,00,000 per year. Overheads: Rs. 1,00,000 per year

Length of Study: Initially for a period of 2 years. In exceptional cases, depending on the progress of research, the fellowship can be extended for 1 more year. There is no provision to extend the tenure beyond 3 years

Country of Study: Hungary 
Application Procedure: The application form along with a research proposal highlighting the objectives of the research work to be undertaken should be submitted online through the website www. serbonline.in.

Additional Information: The call for applications for SERB-N PDF will be notified twice a year through the websites www.serbonline.in and www.serb.gov.in. For details one may visit http://serbonline.in/ SERB/npdf.

\section{Prime Minister's Fellowship Scheme for Doctoral \\ Research}

Subjects: Science, Technology, Engineering, Agriculture or Medicine.

Purpose: To conduct scientific and industrial research.

Level of Study: Research

Type: Fellowship

Value: Rs. 6 lakh per year

Length of Study: 4 years

Frequency: Annual

Country of Study: India

No. of awards offered: 100

Application Procedure: Application Performa is to be filled only through the web portal www.primeministerfellowshipscheme.com. Closing Date: Anytime within 14 months from registration/admission in $\mathrm{PhD}$

\section{Funding: Government}

Contributor: Department of Science \& Technology (DST) and Science \& Engineering Research Board (SERB) with The Confederation of Indian Industry (CII)

Additional Information: For online applications, visit website: www. primeministerfellowshipscheme.com.

\section{Ramanujan Fellowship}

Subjects: All areas of science.

Purpose: The fellowship is meant for brilliant scientists and engineers from all over the world to take up scientific research positions in India, that is, for those scientists who want to return to India from abroad. The fellowships are scientist-specific and very selective. The

Ramanujan Fellows could work in any of the scientific institutions and universities in the country and they would be eligible for receiving regular research grants through the extramural funding schemes of various S\&T agencies of the Government of India.

Level of Study: Postdoctorate

Type: Fellowship

Value: Rs. 85,000 per month and in addition a Research Grant of

Rs. 7.00 lakh per year

Length of Study: 5 years

Application Procedure: Visit website www.serb.gov.in for further details.

Funding: Government

Additional Information: Ramanujan Fellowship are only for those candidates who are doing Post Doctoral abroad and not for the people who already have a permanent position in a scientific organization in the country.

For further information contact:

Contact: Mr S.S. Kohli, Scientist G

\section{SERB Distinguished Fellowship}

Purpose: In order to support research of eminent scientists who do not hold any administrative roles and functions but are active and performing, SERB has instituted Distinguished SERB Fellowship Award.

Eligibility: Superannuated scientist who is active in research. Must have received recognition for his/her work from National and/or International scientific bodies.

Level of Study: Research

Type: Fellowship

Value: A research grant of Rs. 5 lakhs per year and a fellowship amount of Rs. 60,000 per month will be given to each fellow

Country of Study: India

Application Procedure: Call for nomination is made from time to time. Nominations are accepted only when the call is made.

Funding: Government
SERB Overseas Postdoctoral Fellowship (OPDF)

Subjects: Materials, Energy, Sustainable Chemistry, Quantum Computing and Spintronics, Complex systems, Theoretical Mathematical Science, Big Data, Mechanobiology/Physical Biology, Bioenergy, Genetic to Physiology, Mental Health, High Performance Computation in Physics, Chemistry, Biology and Mathematics, Humanoid Robotics, Cognitive Science, Mechnotronics, Advanced Manufacturing, Cyber security, Encryption and decryption, Petroleum and Petro-Chemical Engineering, Science of Climate Change, Glaciology, Modeling, Imaging, Algorithms and Combinatorial Optimizations Application.

Purpose: SERB Overseas Postdoctoral fellowship (SERB-OPDF) aims to build national capacity in frontier areas of Science and Engineering, which are of interest to India by providing postdoctoral fellowship.

Eligibility: The applicant should have completed $\mathrm{PhD}$ degree in science and engineering not earlier than the preceding 2 years from recognized institutions in India. For researchers who are in regular employment, the 2 years period may be relaxed.

Type: Fellowship

Length of Study: 1 year, extendable to 1 more year subject to good performance

Application Procedure: The format, guidelines and other details of the SERB-OPDF Program details are also available at www.dst.gov.in.

Additional Information: The programme admits candidates in identified areas and sends them to top institutions around the globe, other than USA and also to institutions where internationally acclaimed scientists are working.

\section{SERB Women Excellence Award}

Purpose: SERB Women Excellence Award is a one-time award given to women scientists below 40 years of age and who have received recognition from any one or more of the following national academies such as Young Scientist Medal, Young Associate etc.

Level of Study: Research

Type: Award

Value: Rs. 5.00 lakh per year

Length of Study: 3 years

Application Procedure: A copy of the proposal (in one file in PDF) may also be sent by email to: doyiltv@nic.in.

Funding: Government

Additional Information: The call for proposals will be notified through the website annually. Women Scientists who have received the award earlier are not eligible to apply again.

\section{SCIENCE AND TECHNOLOGY FACILITIES COUNCIL (STFC)}

Polaris House, North Star Avenue, Wiltshire, Swindon, SN2 1SZ, England

Tel: (44) 01793442000

Fax: (44) 01793442002

Email: enquiries@stfc.ac.uk

Website: www.stfc.ac.uk

STFC is keeping the UK at the forefront of international science and tackling some of the most significant challenges facing society such as meeting our future energy needs, monitoring and understanding climate change, and global security. The Council has a broad science portfolio and works with the academic and industrial communities to share its expertise in materials science, space and ground-based astronomy technologies, laser science, microelectronics, wafer scale manufacturing, particle and nuclear physics, alternative energy production, radio communications and radar.

\section{Daphne Jackson Fellowships}

Subjects: Particle physics, particle astrophysics, solar system science and astronomy.

Purpose: To enable high-level engineers and scientists to return to their professions after a career break for family or other reasons. Eligibility: Open to promising engineers and scientists who have taken a career break.

Level of Study: Research, Postdoctorate

Type: Fellowship 
Value: Fellowship will be financed by your sponsor and/or host institution. Please refer to the website for more details: www. daphnejackson.org/fellowships/funding/

Length of Study: 2 years

Frequency: Annual

Study Establishment: Any academic institution acceptable to the PPARC

Country of Study: United Kingdom

No. of awards offered: Varies

Application Procedure: Applicants must contact Jennifer Woolley,

Trust Director, or Sue Smith, Fellowship Administrator, for application

forms and further information.

Closing Date: Please write for details

Funding: Government

Additional Information: Please refer to the website for more details:

www.daphnejackson.org/fellowships/applicationprocess/

\section{For further information contact:}

The Daphne Jackson Trust, Department of Physics, University of Surrey, Guildford, Surrey, GU2 7XH, England

Tel: (44) 01483689166

Email:djmft@surrey.ac.uk

Website: www.daphnejackson.org/fellowships/

\section{Industrial CASE Studentships}

Subjects: Science and engineering.

Purpose: To give promising students experience outside a purely academic environment.

Eligibility: Advice on eligibility should be sought from the Registrar's Office.

Level of Study: Postgraduate

Type: Studentship

Value: An annual cash contribution to the academic partner towards the cost of the project of at least $£ 1,400$ per year, for the period during which research data are being collected and analysed - a minimum of 80 per cent of the approved length of the studentship. A mandatory cash payment of at least $£ 2,500$ per year as a supplement to the stipend awarded by MRC for the entire length of the studentship award. This requirement may be increased by $\mathrm{MRC}$ during the course of the project Length of Study: 3.5 years

Frequency: Annual

Country of Study: United Kingdom

Application Procedure: Contact the PPARC.

Closing Date: July 8th

Funding: Commercial

Additional Information: Please check at www.mrc.ac.uk/skillscareers/studentships/how-we-fund-studentships/industrial-casestudentships/ for more information.

\section{Industrial CASE-Plus Studentship}

Subjects: Science and engineering.

Purpose: To help students become more effective in promoting technology transfer.

Eligibility: Advice on eligibility should be sought from the Registrar's Office.

Level of Study: Postgraduate

Type: Studentship

Value: Up to $£ 14,250$

Length of Study: 3.5 years

Frequency: Annual

Country of Study: United Kingdom

Application Procedure: The Call opens May. Proposals may be submitted up to the closing date of July for awards to start in October. Proposals should be submitted by a supervisor from a Research Organization eligible to be the academic partner through the Je-S system. Funding: Commercial

Additional Information: Please check at www.stfc.ac.uk/funding/ studentships/types-of-postgraduate-studentship/ OR contact to studentships@stfc.ac.uk for more information.

\section{PPARC Advanced Fellowships}

Subjects: Particle physics, astronomy and solar system science. Level of Study: Postdoctorate

Type: Fellowship
Value: Advanced Fellowships provide funds to cover the Fellow's salary, the costs of personal travel associated with the fellowship and some minor equipment costs

Frequency: Annual

Country of Study: United Kingdom

No. of awards offered: 12

Application Procedure: Applications for a PPARC Fellowship must be submitted using the Je-S system.

Closing Date: October 13th

Additional Information: You may undertake up to a maximum of six hours teaching, including preparation each working week.

For further information contact:

Email: Clare.Heseltine@pparc.ac.uk

Contact: Clare Heseltine

\section{PPARC Gemini Studentship}

Subjects: Astronomy.

Purpose: To enable promising South-American students to pursue a PhD in Great Britain.

Eligibility: Open to students from Argentina, Brazil or Chile only.

Level of Study: Doctorate

Type: Fellowship

Value: Agreed tuition costs and a maintenance allowance

Length of Study: 3 years

Frequency: Annual

Country of Study: United Kingdom

No. of awards offered: 3

Application Procedure: See website.

Closing Date: March 31st

Additional Information: Please check the website for further details www.prospects.ac.uk/funding_award_details.htm?id =569.

\section{PPARC Postdoctoral Fellowships}

Subjects: Particle physics, astronomy and solar system science. Level of Study: Postgraduate

Type: Fellowship

Value: All agreed salary, travel and subsistence, equipment, addi-

tional costs, and UK£1,500 stipend

Frequency: Annual

Country of Study: United Kingdom

No. of awards offered: 12

Application Procedure: Applications for a PPARC Fellowship must be submitted using the Je-S system.

Closing Date: October 15th

Additional Information: The Postdoctoral Fellowships scheme has not made any new awards since the $2009 / 10$ round.

\section{Spanish (IAC) Studentship}

Subjects: Astronomy.

Purpose: To support students of the Instituto de Astrofiscia de

Canarias (IAC), Tenerite, Spain pursuing a PhD in Great Britain.

Eligibility: Open to Spanish students of the Instituto de Astrofiscia de Canarias (IAC) only.

Level of Study: Doctorate

Type: Studentship

Value: Agreed tuition costs and a maintenance allowance

Length of Study: 3 years

Frequency: Annual

Country of Study: United Kingdom

No. of awards offered: 2

Closing Date: March 31st

Additional Information: Please check at www.stfc.ac.uk/funding/

studentships/types-of-postgraduate-studentship/ for more information.

\section{STFC Postgraduate Studentships}

Subjects: Particle physics, particle astrophysics, solar system science and astronomy.

Eligibility: Open to postgraduates from the U.K. and EU countries. All studentship projects supported through STFC funding must fall within STFC remit.

Level of Study: Postgraduate

Type: Studentship

Value: Stipend (excluding fees only students), approved fees

Research Training Support Grant, Conference and U.K. fieldwork 
element, Fieldwork expenses, Long Term Attachments, Other Allowances (where applicable)

Length of Study: Up to 3 years

Frequency: Annual

Country of Study: United Kingdom

No. of awards offered: Approx. 185

Closing Date: March 31st

Funding: Government

Additional Information: Please check at www.stfc.ac.uk/funding/ studentships/types-of-postgraduate-studentship/ for more information.

\section{For further information contact:}

Tel: 01793413195

Fax: 01793442036

Email: Studentships@stfc.ac.uk

\section{SCIENCE FOUNDATION IRELAND}

\author{
Wilton Park House, Wilton Place, Dublin 2, Ireland \\ Tel: (353) 16073200 \\ Fax: (353) 16073201 \\ Email: info@sfi.ie \\ Website: www.sfi.ie \\ Contact: Professor Mark W. J. Ferguson, Director
}

Science Foundation Ireland funds oriented basic and applied research in the areas of science, technology, engineering and mathematics (STEM), which promotes and assists the development and competitiveness of industry, enterprise and employment in Ireland. SFI will build and strengthen scientific and engineering research and its infrastructure in the areas of greatest strategic value to Ireland's longterm competitiveness and development.

\section{President of Ireland Young Research Award (PIYRA)}

Subjects: Science, technology, engineering, and mathematics. Purpose: The purpose of the PIYRA programme is to recruit and retain outstanding early career investigators with leadership potential. Its aim is to enable those at an earlier career stage who already hold permanent academic positions to advance their careers and build up their research teams and activities; to allow researchers in temporary positions to advance their careers and provide them with enhanced opportunities to move into a permanent academic position; to enable the award holder, together with his/her team, to carry out their work in Ireland's public research bodies; to offer funding opportunities that help third-level institutions attract and develop researchers and their careers; to allow earlier-career investigators of all nationalities to enhance their experience in Irish HEls and to allow those employed outside of Ireland to return to work in an Irish HEI.

Eligibility: The lead applicant must have completed a minimum of 36 months of active postdoctoral research. The lead applicant must have been awarded a PhD or MD within the last 8 years, in the normal case, or up to a maximum of 12 and a half years for applicants who have taken documented eligible leave, as described below. The lead applicant has an exceptional record of internationally recognized independent research accomplishments for their career stage. The lead applicant must be an individual who will be recognized by the research body upon receipt of the SFI grant as an independent investigator who will have an independent office and research space at the host research body for which he/she will be fully responsible for at least the duration of the SFI grant.

Level of Study: Research

Type: Grant

Value: Up to $€ 1,000,000$ of total value (inclusive of the host institution contribution) in direct costs

\section{Length of Study: Up to 5 years}

Study Establishment: Host Research Bodies must be situated in the Republic of Ireland. Research Bodies will include Universities, Institutes of Technology and independent not-for-profit public research organizations that receive a significant share of their total funding from public sources

Country of Study: Ireland

Application Procedure: Applicants are invited to submit the following documentation: expression of Interest and if invited to do so after the Expression of Interest evaluation stage; full proposal. Application must be submitted via an eligible research body. Application must be submitted online via SESAME.
Closing Date: Rolling call. Closes by December 21st

Funding: Government

Contributor: Science Foundation Ireland

\section{SFI Career Development Award (CDA)}

Subjects: Science, technology, engineering and mathematics. Purpose: The SFI Career Development Award (CDA) aims to support early- and mid-career researchers who already hold a salaried, independent research post and who are looking to expand their research activities. Its aims is to support excellent scientific research that has potential economic and societal impact; to enable those at an earlier career stage who already hold permanent academic positions to advance their careers and build up their research teams and activities; to allow researchers in temporary positions to advance their careers and provide them with enhanced opportunities to move into a permanent academic position; to provide the support and infrastructure to carry out novel research in areas that underpin SFI's legal remit; to enable the award holder, together with his/her team, to carry out their work in Ireland's public research bodies, including Universities and Institutes of Technology; to offer funding opportunities that help third-level institutions attract and develop researchers and their careers; to allow earlier-career investigators of all nationalities to enhance their experience in Irish HEls.

Eligibility: The applicant will be a researcher with 3-15 years of relevant experience beyond the award of their doctoral degree, who at the time of application will be either in a permanent, full-time academic position (either within the institution at which they wish to base their CDA-funded research or another elsewhere in Ireland or overseas), or employed on a temporary (fixed-term) contract where it is evident that the role being carried out is an independent research position (i.e., Postdoctoral Research Associates (or equivalent) or Research Fellows working under the guidance of a supervisor and who have never held an independent position are not eligible to apply to the CDA Programme)

Level of Study: Research

Type: Award

Value: Between $€ 300,000$ and $€ 500,000$ direct costs

Length of Study: 4 years

Frequency: Every 2 years

Study Establishment: Host Research Bodies must be situated in the Republic of Ireland. Research Bodies will include Universities,

Institutes of Technology and independent not-for-profit public research organizations that receive a significant share of their total funding from public sources

Country of Study: Ireland

No. of awards offered: Varies

Application Procedure: Application must be submitted via an eligible research body. Application must be submitted online via SESAME (www.sfi.ie/funding/award-management-system).

Closing Date: December 10th (subject to change, please consult call document)

Funding: Government

Contributor: Science Foundation Ireland

No. of awards given last year: 20

Additional Information: Please write to cda@sfi.ie for further information.

\section{SFI Investigator Programme}

Subjects: Science, technology, engineering and mathematics that demonstrably support and underpin enterprise competitiveness and societal development in Ireland.

Purpose: To fund scientific research projects of excellence in focused areas. To build capacity, expertise and relationships so as to enable researchers to compete in future SFI Research Centre Programmes or in other funding programmes such as ERC and Horizon 2020. To encourage researchers to build capacity, expertise, collaborations and relationships in areas of strategic economic importance through themed calls. To facilitate partnerships with other agencies. To support collaborations and partnerships between academia and industry.

Eligibility: The lead applicant and any co-applicant(s) must hold a $\mathrm{PhD} / \mathrm{MD}$ or equivalent for at least 5 years by the proposal deadline. The lead applicant and any co-applicant(s) are required to have demonstrated that they are each senior author on at least 10 
international peer reviewed articles. The lead applicant and any co-applicant(s) are required to have demonstrated research independence through securing at least one independent research grant as a lead investigator or as co-investigator.

Level of Study: Research

Type: Grant

Value: $€ 400,000-2,500,000$ per year

Length of Study: $3-5$ years

Frequency: Annual

Study Establishment: Host Research Bodies must be situated in the Republic of Ireland. Research Bodies will include Universities,

Institutes of Technology and independent not-for-profit public research organizations that receive a significant share of their total funding from public sources

Country of Study: Ireland

No. of awards offered: Varies

Application Procedure: Application must be submitted via an eligible research body. Application must be submitted online via SESAME (www.sfi.ie/funding/award-management-system).

Closing Date: June 26th (subject to change, please consult call document)

Funding: Government

Contributor: Science Foundation Ireland

No. of awards given last year: 40

For further information contact:

Email: investigators@sfi.ie

Website: www.sfi.ie/funding/funding-calls/open-calls/investigatorsprogramme-2014.html

\section{Starting Investigator Research Grant (SIRG)}

Subjects: Science, technology, engineering and mathematics. Purpose: The SIRG programme supports excellent postdoctoral researchers who wish to take steps towards a fully independent research career. Aims: to support excellent scientific research that has potential economic and societal impact. To enable those at an early career stage to establish themselves as independent researchers; to provide the support and infrastructure to carry out novel research in areas that underpin SFI's legal remit; to gain important experience towards a full-time academic position, including the supervision of the postgraduate student supported by the award; to enable the award holder, together with his/her postgraduate student, to carry out their work in Ireland's public research bodies, including Universities and Institutes of technology; to offer funding opportunities that help thirdlevel institutions attract and develop researchers and their careers; to allow early-career investigators of all nationalities to enhance their experience in Irish HEls; to allow early-career investigators who have been employed outside of Ireland to return to work in an Irish HEI. Eligibility: The applicant will be a researcher with between 3 and 8 years of relevant experience beyond the award of their doctoral, who is currently employed as a Postdoctoral Research Associate (or equivalent) or a Research Fellow under the guidance of a named supervisor, and who has never previously held an independent research position of any kind where they were primarily responsible for a research team and its financial support. Allowances will be made for documented leave, including maternity leave, paternity leave, parental leave, military service, sick/disability leave and carer's leave.

Level of Study: Research

Type: Grant

Value: Up to $€ 400,000$ direct costs

Length of Study: 4 years

Frequency: Every 2 years

Study Establishment: Host Research Bodies must be situated in the Republic of Ireland. Research Bodies will include Universities,

Institutes of Technology and independent not-for-profit public research organizations that receive a significant share of their total funding from public sources

Country of Study: Ireland

Application Procedure: Application must be submitted via an eligible research body. Application must be submitted online via SESAME.

Closing Date: November 26th (subject to change, please consult call document)

Funding: Government

Contributor: Science Foundation Ireland

No. of awards given last year: 20

\section{For further information contact:}

Email: sirg@sfi.ie

Website: www.sfi.ie/funding/award-management-system

\section{SCIENCES PO}

\author{
rue Saint Guillaume, PARIS, 75337, France \\ Tel: (33) (0)1 45495050 \\ Contact: Sciences Po - 27
}

Sciences Po, or Paris Institute of Political Studies, is a selective university located in Paris, France. Its main campus is located on rue Saint-Guillaume in the 7th arrondissement.

\section{David Gritz Scholarship}

Purpose: The David Gritz Scholarship is meant to attract undergraduate and graduate Israeli citizens who wish to study at Sciences Po. Eligibility: The scholarship is awarded every year to 1 Israeli citizen. The candidates must be admitted to an undergraduate or a masters programme or have submitted an application for admission to Sciences Po.

Level of Study: Postgraduate

Type: Scholarship

Value: $\$ 10,000$ per year

Length of Study: 1 year

Country of Study: France

No. of awards offered: 1

Application Procedure: Applicants must send the forms to caterina. sabbatini@sciencespo.fr.

Closing Date: June 1st

Contributor: Sciences Po Foundation

Additional Information: For more details contact Caterina SabbatiniClec'h, caterina.sabbatini@sciencespo.fr.

\section{Emile Boutmy Scholarships}

Subjects: Masters programme offered at the University.

Purpose: Sciences Po created the Emile Boutmy Scholarships after the founder of Sciences Po in order to attract the very best international students from outside of the European Union who are first time applicants and who have been admitted to an undergraduate or master's programme offered at the University.

Eligibility: Non-EU international students. This scholarship is awarded based on factors of excellence and according to the type of profile sought for this programme. Social criteria are also taken into account.

Level of Study: Postgraduate

Type: Scholarship

Value: From $€ 5,000$ to $€ 16,000$ for 2 years of the master's programme Length of Study: 2 years

Frequency: Annual

Country of Study: France

No. of awards offered: Not specified

Application Procedure: It is important to visit the official website to access the application form and for detailed information on how to apply for this scholarship.

Closing Date: May 2nd

Contributor: Sciences Po Foundation

Additional Information: For more details, please visit official scholarship website: http://formation.sciences-po.fr/en/contenu/ the-emile-boutmy-scholarship.

\section{KSP Excellence Scholarship for Arab students}

Purpose: The KSP Excellence Scholarship for Arab students intends to support the next generation of leaders and experts coming from the Arab World and the Gulf Region who specialize in the broad field of international affairs. The current call for applications is dedicated to graduate students admitted to the Paris School of International Affairs of Sciences Po (PSIA).

Type: Scholarship

Value: 2 -year master's programme: $€ 10,000$ per year (up to $€ 20,000$ for 2 years of study). 1-year master's programme: $€ 19,000$ for 1 year of study

No. of awards offered: 1 of PSIA's 2-year master programmes and 1 -year master in advanced global studies 
Application Procedure: To apply, please send the following materials by email to program.kuwait@sciencespo.fr with 'KSP Excellence Scholarship Application 2016' in the subject line. Closing Date: January 10th

\section{KSP Excellence Scholarship for Least Developed \\ Countries \\ Subjects: Any field of study.}

Purpose: The KSP Excellence Scholarship for Least Developed Countries is directed to outstanding students, covering full tuition. Level of Study: Postgraduate

Type: Scholarship

Value: Each recipient is awarded full tuition each year

Frequency: Annual

Country of Study: France

Application Procedure: To apply, please send the following materials by email to program.kuwait@sciencespo.fr with 'KSP

Excellence Scholarship LDC Application 2016' in the subject line. Closing Date: January 10th

Contributor: Sciences Po and the Kuwait Foundation for the Advancement of Sciences (KFAS)

\section{KSP Fund for Innovative Projects}

Purpose: The KSP Fund for Innovative Projects supports extracurricular student-led initiatives taking place in countries of the Arab World and the Gulf Region. It is aimed at fostering innovation and providing funding for the realization of creative ideas benefiting the region in all sectors.

Level of Study: Postgraduate

Value: $€ 5,000-€ 10,000$

Application Procedure: To apply, please send the following materials with 'KSP Fund for Innovative Projects' in the subject line, by email to the Kuwait Program Assistant at: fatima.iddahamou@ sciencespo.fr.

Closing Date: February 28th

Additional Information: Proposed projects must take place in a country of the Arab World or the Gulf Region. For further details, please contact Kuwait Program Assistant, Fatima Iddahamou: fatima. iddahamou@sciencespo.frwww.sciencespo.

\section{KSP Joint Research Projects 2017-2018}

Subjects: Social sciences and humanities.

Purpose: KSP Joint Research Projects are funded by the Kuwait Program at Sciences Po to foster research links between faculty members at Sciences Po and in Kuwait, in the interest of building a unique scholarly network.

Level of Study: Research

Value: Up to $€ 50,000$

Length of Study: 1 year

No. of awards offered: Not specified

Application Procedure: Application files should be sent to the Kuwait Program Manager at: mariezenaide.jolys@sciencespo.fr.

Closing Date: October 31st

Funding: Foundation

Contributor: Sciences Po and the Kuwait Foundation for the Advancement of Sciences (KFAS)

Additional Information: For details, please check the website: www. sciencespo.fr/psia/kuwait-program.

\section{KSP Mobility Grant - Spring 2017}

Purpose: The KSP Mobility Grant programme supports projects of Sciences Po students in countries of the Arab World and the Gulf Region with the objective of enhancing their experience in the region. Eligibility: Sciences Po students of all nationalities may apply.

Student projects must take place in a country of the Arab World or the Gulf Region.

Level of Study: Postgraduate, Research

Type: Grant

Value: Up to $€ 5,000$ per year

Frequency: Annual

No. of awards offered: Not specified

Application Procedure: To apply, please send the following materials to the Kuwait Program Assistant, Fatima Iddahamou, at: fatima.iddahamou@sciencespo.fr with 'KSP Mobility Grant Application Spring 2017' in the subject line.
Closing Date: October 31st

Additional Information: For details, please contact Kuwait Program Assistant, Fatima Iddahamou: fatima.iddahamou@sciencespo.fr.

\section{KSP Visiting Faculty program}

Subjects: Social sciences and humanities.

Purpose: The KSP Visiting Faculty program offers 1-semester teaching opportunities at the Paris School in International Affairs of Sciences Po (PSIA) for leading specialists of the Arab World and the Gulf Region. Eligibility: This opportunity is open to both professors and practitioners, specialists of the Arab World and the Gulf Region. Individuals of all nationalities may apply.

Value: $€ 20,000$ Euros and travel allowance of up to $€ 1,500$

Country of Study: Any country

No. of awards offered: 2

Application Procedure: To apply, please send the application in English to the Kuwait Program Manager by email at: mariezenaide. jolys@sciencespo.fr.

Closing Date: January 31st

Additional Information: For more information, please visit the Kuwait Program website or contact the Kuwait Program Manager by email at: mariezenaide.jolys@sciencespo.fr.

\section{THE SCIENTIFIC AND TECHNOLOGICAL RESEARCH COUNCIL OF TURKEY}

Tunus Caddesi No: 80, 06100, Ankara, Kavaklıdere, Turkey Tel: (90) 03124685300

Website: www.tubitak.gov

\section{TÜBITAK Research Fellowship Programme for Foreign Citizens in Turkey}

Subjects: Natural sciences, engineering and technological sciences, medical sciences, agricultural sciences, social sciences and humanities.

Purpose: The program aims to promote Turkey's scientific and technological collaboration with countries of the prospective researchers.

Eligibility: Applicants should be non-Turkish citizens. Applicants who hold dual citizenship with Turkey are not eligible to apply. Applicants should have an invitation from the universities or research institutes in Turkey. Applicants should certify that they have sufficient command of the language to perform their research. Applicants must be 35 years old or younger. Applicants should be enroled in a program abroad for PhD students. Applicants who hold a PhD degree in Turkey should have a GPA minimum of 3.50/4.00.

Type: Fellowship

Value: A monthly stipend of 2.250 Turkish Liras. Travel costs (round trip up to 2,250 Turkish Liras) and Health insurance premiums (up to 2,250 Turkish Liras). If approved by TÜBITAK Department of Science Fellowships and Grant Programs (BIDEB) Steering Committee, travel costs and health insurance for the fellow may be partially covered

Length of Study: Maximum duration for the fellowship is 12 months Application Procedure: All applications must be submitted electronically via TÜBITAK scholarship application portal, which can be reached at http://e-bideb.tubitak.gov.tr/. All accompanying required documents must also be uploaded electronically. In order to complete the application process, applicants must approve their applications by $17.30 \mathrm{pm}$ on the application deadline.

Closing Date: October 19th

Additional Information: For further information, please visit www. tubitak.gov.tr/en/funds/academy/international-researchers-fellowshipprogrammes/2216/content-e-application.

\section{SCOTTISH RITE CHARITABLE FOUNDATION OF CANADA (SRFC)}

4 Queen Street South, Hamilton, ON, L8P 3R3, Canada Tel: (1) 9055220033

Fax: (1) 9055223716

Email: info@srcf.ca

Website: www.srcf.ca

Contact: Manager Information Services 
The Scottish Rite Charitable Foundation of Canada (SRFC) is a private charitable foundation, funded by donations and bequests from the 26,000 members of the ancient and accepted SRFC. The SRFC labours for the benefit of all Canadians, regardless of race or creed. Over the years millions of dollars have been disbursed to assist dedicated researchers in a search for the causes and cure of intellectual impairment.

\section{SRFC Graduate Student Research Awards}

Subjects: Health and medical sciences.

Purpose: To support students registered in a Doctoral research programme focused on the physical-biological or social aspects of intellectual impairment.

Eligibility: Open to candidates who are enroled in a Doctoral programme at a Canadian university or research hospital. Applicants must be citizens or a permanent resident of Canada.

Level of Study: Doctorate

Type: Research award

Value: Up to Canadian $\$ 10,000$

Length of Study: 2 years

Frequency: Annual

Country of Study: Canada

Application Procedure: Application package consists of the application form and application guide. Application form is available online. Closing Date: April 30th

Funding: Foundation

\section{SRFC Major Research Grant for Biomedical Research into} Intellectual Impairment

Subjects: Health and medical sciences.

Purpose: To support biomedical research into intellectual impairment. Eligibility: Open to researchers who have or are offered at least a 3 year academic appointment at a Canadian university or research hospital. Applicants must be Canadian citizens or permanent resident. Level of Study: Research

Type: Research grant

Value: Canadian $\$ 35,000$

Length of Study: Up to 3 years

Country of Study: Canada

No. of awards offered: 10

Application Procedure: Applicants must submit their application form and research proposal.

Closing Date: April 30th

Funding: Foundation

Additional Information: The focus of research should be on the causes and cure of the disease as opposed to the active treatment or palliative care.

\section{SCOULOUDI FOUNDATION}

The Institute of Historical Research, University of London, Senate House, Malet Street, London, WC1E 7HU, England Tel: (44) 2078628740 Fax: (44) 2078628745

Email: james.lees@sas.ac.uk

Website: www.history.ac.uk

Contact: James Lees, Fellowships Officer

The IHR is an important resource and meeting place for scholars from all over the world. It contains an outstanding open access library, runs courses and major conferences, offers research fellowships and other awards and produces many significant research aids and tools.

\section{Economic History Society Research Fellowships}

Subjects: Economic and social history.

Purpose: To help candidates at an advanced stage of a $\mathrm{PhD}$ to complete their doctorates or to fund 1 year of postdoctoral study in history.

Eligibility: Open to postdoctoral candidates who have recently completed a doctoral degree in economic or social history or to graduates who are engaged in the completion of a doctoral degree in economic or social history and who have completed 2 years, but not more than 4 years of full-time or 8 years part-time research on their chosen topics. Fellowships are open to citizens of the UK or to candidates with a degree from a university in the UK.
Level of Study: Doctorate, Postdoctorate

Type: Fellowship

Value: $£ 13,590$ (affiliated to institutions outside London); $£ 15,590$

(affiliated to London-based institutions)

Length of Study: 1 year

Frequency: Dependent on funds available

Study Establishment: An institute of historical research

Country of Study: England

No. of awards offered: Up to 5

Application Procedure: Applicants must complete an application form, available from the Fellowship Officer in early January.

Closing Date: April 13th

Funding: Foundation

Contributor: The Economic History Society

No. of awards given last year: 3

\section{Scouloudi Historical Awards: Research Awards}

Subjects: History or a related subject.

Purpose: To provide subsidies towards the cost of publishing a book or article in the field of history, incorporating an academic thesis or other scholarly work already accepted by a reputable publisher or learned journal or to pay for special expenses incurred in the completion of advanced historical work such as the cost of fares and subsistence during visits to libraries or record repositories.

Eligibility: Open to graduates of U.K. universities who possess a relevant Honours degree, or U.K. citizens with a similar qualification from a university outside the UK. These awards are not made for study or research towards a postgraduate qualification, e.g. work on thesis for higher degrees.

Level of Study: Postgraduate

Type: Varies

Value: Up to $£ 1,000$

Study Establishment: None

Country of Study: Any country

No. of awards offered: Varies

Application Procedure: Applicants must complete an application form.

Closing Date: March 11th

Funding: Private

Contributor: The Scouloudi Foundation

\section{SDA BOCCONI}

School of Management - via Bocconi, 8, Milano, 20136, Italy Tel: (39) 025836 6605/6606

Fax: (39) 0258366638

Email: oriana.ghinato@sdabocconi.it

Website: www.sdabocconi.it/en

Contact: Oriana Ghinato, Secretary

SDA School of Management enjoys recognition as a leading management school at an international level. Its mission is to educate men and women to be ready to act anywhere in the world, using their knowledge and imagination.

\section{MPM Partial Tuition Fee Waivers}

Subjects: Master of Public Management (MPM) is described as an MBA but focused on the international public sector. MPM is designed to prepare individuals for careers in Governmental organizations, international institutions, NGOs and private businesses working with the public sector. The MPM programme provides a learning environment for participants from all 5 continents and is taught entirely in English.

Purpose: To provide partial tuition fee waivers for deserving candidates.

Eligibility: The MPM is open to candidates from different backgrounds and age groups. However, candidates with a background/ interest in political science or international affairs will get the most from the MPM. Work experience is preferred but not essential.

Level of Study: Postgraduate

Type: Scholarship

Length of Study: 1 year

Frequency: Annual

Study Establishment: SDA Bocconi, Bocconi University, Milan Country of Study: Italy 
Application Procedure: Applicants must send a completed application form which is available online at www.sdabocconi.it $/ \mathrm{mpm}$ along with a curriculum vitae, transcripts of the GMAT/GRE/TOEFL (or other) scores, 2 reference letters and 4 passport size photographs, in a sealed envelope, to the course Secretary.

Closing Date: July (check the website)

Additional Information: MPM operates a rolling application process. Applications are assessed until the course is full. Candidates whose mother tongue is English or who have studied in institutions where the medium of instruction is English may request a waiver for the English language certificate such as TOEFL (or other).

For further information contact:

Room 115, SDA Bocconi, Via Bocconi, 8, Milan, 20136, Italy Contact: Joanne Matthews, Secretary, MPM Master Division

\section{SEMICONDUCTOR RESEARCH CORPORATION (SRC)}

PO Box 12053, Research Triangle Park, NC, 277092053 United States of America

Tel: (1) 9199419400

Fax: (1) 9199419450

Email: students@src.org

Website: www.src.org

Contact: Sarah Jackson, Program Officer

The Semiconductor Research Corporation (SRC) is a consortium of about 60 semiconductor manufacturers and equipment makers. The $\mathrm{SRC}$ manages a research portfolio in major research universities throughout the world. At any given time it supports about 700 advanced degree students on contract research, 45 graduate Fellows and 15 Master's scholars. The SRC supports a pragmatic approach to developing student programmes and provides industry interactions and other opportunities for its students.

\section{GRC Graduate Fellowship Program}

Subjects: Electrical engineering, computer engineering, chemical engineering, mechanical engineering, materials science, physics and related areas.

Purpose: To support academically gifted doctoral students in research areas consistent with SRC goals.

Eligibility: Open to Doctorate students with academic excellence and depending on the candidate's contribution to the field. Recipients are required to be associated with an SRC-funded contract.

Level of Study: Doctorate

Type: Fellowship

Value: Full tuition and fees and a competitive stipend

Length of Study: Up to 5 years or until completion of degree,

whichever comes first

Frequency: Annual

Study Establishment: Universities having SRC-funded contracts.

See src.org for details

Country of Study: United States of America

No. of awards offered: 5

Application Procedure: Applicants must compute an application

form. Applications are distributed through SRC-funded faculty in

November and are due in early February. Application materials are

also available at www.src.org.

Closing Date: February 15th

Funding: Commercial

Contributor: The semiconductor industry

No. of awards given last year: 9

No. of applicants last year: 100

Additional Information: Resources are available to assist qualified students in identifying suitable faculty with SRC-supported research. SRC contracts support precompetitive research in areas of interest to the semiconductor industry. Please see the website for further details www.src.org/student-center/fellowship/.

\section{GRC Master's Scholarship Program}

Subjects: Electrical engineering, computer engineering, chemical engineering, mechanical engineering, materials science, physics and related areas.
Purpose: To attract underrepresented minorities and women to disciplines of interest to the semiconductor industry.

Eligibility: Open to students having U.S. citizenship or permanent resident status. Students are also required to be from an underrepresented group, e.g. women, African American, Latino or Native American students must be pursuing or planning to pursue Master's research with an SRC-funded faculty.

Type: Scholarship

Value: Please contact the organization

Length of Study: 2 years or until completion of the Master's degree, whichever comes first

Frequency: Annual

Study Establishment: Universities having SRC-funded contracts. A list is available at the website

Country of Study: United States of America

No. of awards offered: Varies

Application Procedure: Applicants must complete an application form. Applications are distributed through SRC-funded faculty in November with a due date early in February. Applications are also distributed through other avenues outside the SRC community and applications are encouraged from non-SRC-funded colleges.

Closing Date: February 15th

Funding: Commercial

Contributor: The semiconductor industry

No. of awards given last year: 1

No. of applicants last year: 9

Additional Information: Recipients are required to be associated with an SRC-funded contract. Resources are available to assist qualified students in identifying suitable faculty within SRC-funded universities. SRC contracts support precompetitive research in areas of interest to the semiconductor industry. Please see the website for further details www.src.org/student-center/fellowship/.

\section{SEOUL NATIONAL UNIVERSITY}

\author{
1 Gwanak-ro, Gwanak-gu, Seoul, 151 742, Korea \\ Tel: (82) 8228806971, 6977 \\ Fax: (82) 8228735021 \\ Email: snuadmit@snu.ac.kr \\ Website: www.useoul.edu \\ Contact: MBA Admissions Officer
}

\section{Korea-Japan Cultural Association Scholarship}

Subjects: Humanities and social-science.

Eligibility: Japanese students enroled in undergraduate programs who are not in 1st-year.

Level of Study: Postdoctorate, Postgraduate, Research

Type: Scholarship

Value: KRW 3,500,000

Length of Study: 1 academic year

Frequency: Annual

Study Establishment: Seoul National University

Country of Study: Korea

Application Procedure: Contact the Office of International Affairs.

Closing Date: March

Funding: Foundation

Contributor: Korea-Japan Cultural Association

For further information contact:

The Office of International Affairs

Tel: 28808638

Fax: 28808632

Email: sjlim@snu.ac.kr

Website: www.useoul.edu/apply/under/scholarships/external

Contact: Mr Sung Sub Yoon

\section{Korean Government Scholarship Program}

Subjects: Korean studies.

Purpose: To further international bilateral cultural agreement with Korea.

Eligibility: Applicants must be under 40 years of age as of

September 1st.

Level of Study: Postdoctorate, Postgraduate, Research

Type: Scholarship 
Value: Full tuition fee (tuition exemption for 8 semesters); living expenses (800,000 KRW per month); airfare (one economy round trip); Korean language training fee (for 1 year); others (medical insurance, settlement and returning expenses)

Length of Study: 4 years

Frequency: Annual

Study Establishment: Seoul National University

Country of Study: Korea

Application Procedure: Contact the Korean Embassy in residing country or see website.

Closing Date: No deadline

Funding: Government

Additional Information: For further details, please refer the website: www.studyinkorea.go.kr

For further information contact:

Website: www.studyinkorea.go.kr

\section{Overseas Koreans Scholarship}

Subjects: Korean studies.

Purpose: To support students with an outstanding academic record. Eligibility: Preference is given to Korean students with majors related to Korean studies, in particular: language, literature, medicine, education or IT, which are beneficial to the development of Korea. Level of Study: Postdoctorate, Postgraduate, Research

Type: Scholarship

Value: KRW 800,000, full tuition exemption for 8 months, airfare for one economic round trip, medical insurance, korean language training Length of Study: 1 year

Frequency: Annual

Application Procedure: Contact the Overseas Korean Foundation. Closing Date: Application Period: September

Additional Information: For further details, please refer to the website: www.useoul.edu/apply/under/scholarships/beforeapplication.

\section{For further information contact:}

Education Department, Overseas Korean Foundation, Seocho 2-dong, Seocho-gu, Seoul, (137-072)

Tel: 234150174

Fax: 234150118

Email: scholarship@okf.or.kr

Website: www.useoul.edu/apply/under/scholarships/external Contact: Coordinator

\section{SHEFFIELD HALLAM UNIVERSITY}

City Campus, Howard Street, Sheffield, S1 1WB, United Kingdom Tel: (44) 01142255555

Fax: (44) 01142254449

Website: www.shu.ac.uk

Sheffield Hallam University is a modern university with a long and proud history, dating from the opening of two 19th century schools which would later become the foundations for Sheffield Polytechnic.

\section{Hallam Special Achievement Scholarships}

Subjects: Scholarships are provided to learn any of the courses offered by the Sheffield Hallam University in UK.

Purpose: The scholarships are available for pursuing undergraduate degree level at Sheffield Hallam University in UK.

Eligibility: Applicants should be registered and enroled for one of the Undergraduate Progression Programme courses in the summer of the current year and have paid all their fees. Applicants must demonstrate some outstanding service or special achievement. The students of Malaysia (students of Tunku Abdul Rahman College) can apply for these scholarships.

Type: Scholarship

Value: $£ 300$ each

Country of Study: United Kingdom

No. of awards offered: 3

Application Procedure: The mode of applying is by email

Closing Date: June 30th

Contributor: Sheffield Hallam University, UK

\section{SHELBY CULLOM DAVIS CENTER FOR HISTORICAL STUDIES}

129 Dickinson Hall, Princeton University, Princeton, NJ, 08544, United States of America Tel: (1) 6092584997

Fax: (1) 6092585326

Email: jhoule@Princeton.EDU

Website: www.princeton.edu

Contact: Ms Jennifer Houle, The Manager

The Davis center for historical studies was founded in 1968 to assure the continuance of excellence in scholarship and the teaching of history at Princeton University.

\author{
Shelby Cullom Davis Center Research Projects, Research \\ Fellowships \\ Subjects: History. \\ Purpose: To support research \\ Eligibility: Applicants must have completed a PhD. \\ Level of Study: Postdoctorate \\ Type: Fellowship \\ Value: US $\$ 2,000$ per semester or $\$ 4,000$ for the year, payable on \\ presentation of a statement of expenses \\ Length of Study: 1-2 semesters \\ Frequency: Annual \\ Study Establishment: Shelby Cullom Davis Center \\ Country of Study: United States of America \\ No. of awards offered: Varies \\ Application Procedure: Applications are available online. \\ Closing Date: December 1st \\ Funding: Private \\ No. of awards given last year: 7
}

\section{SHORENSTEIN ASIA-PACIFIC RESEARCH CENTER (APARC)}

Encina Hall, Room E301, 616 Serra Street, Stanford University, Stanford, CA, 94305-6055, United States of America Tel: (1) 6507239741

Fax: (1) 6507252592

Email: sishi@stanford.edu

Website: www.aparc.stanford.edu

Shorenstein Asia-Pacific Research Center (APARC) is an important Stanford venue where faculty and students, visiting scholars and distinguished business and government leaders meet and exchange views on contemporary Asia and US involvement in the region.

\section{Shorenstein Fellowships in Contemporary Asia}

Subjects: Contemporary political, economic and social change in the Asia-Pacific region.

Purpose: To financially support research and writing on Asia.

Eligibility: Open to candidates who have obtained a PhD.

Level of Study: Postdoctorate, Doctorate

Type: Fellowships

Value: The postdoctoral fellowship is a 10-month appointment with a salary rate of $\$ 52,000$ plus $\$ 2,000$ for research expenses

Length of Study: 10 months

Frequency: Annual

Country of Study: Asia

No. of awards offered: 2

Application Procedure: Applicants should submit via email brief research statement (not to exceed five typed pages), which describes the research and writing to be undertaken during the fellowship period as well as the proposed publishable product; curriculum vitae and three letters of recommendation.

Closing Date: December 18th

Funding: Private

No. of awards given last year: 2

No. of applicants last year: $75+$ 
For further information contact:

Tel: 6507232408

Email: shorensteinfellowships@stanford.edu

Website: http://aparc.stanford.edu/fellowships/

shorenstein_fellowships_in_contemporary_asia

Contact: Victoria Kwong, Fellowship Coordinator

\section{THE SHUTTLEWORTH FOUNDATION TRUST}

12 Plein St, Durbanville, Cape Town, 7550, South Africa Website: www.shuttleworthfoundation.org

\section{Feminist Criminology Graduate Research Scholarship}

Purpose: The Division on Women and Crime of the American Society of Criminology is now accepting applications for the Feminist Criminology Graduate Research Scholarship, which is designed to recognize an exceptional graduate student in the field of gender and crime.

Level of Study: Graduate, Research

Type: Scholarship

Value: US $\$ 5,000$ to support a project involving original research Frequency: Annual

No. of awards offered: 1

Application Procedure: Winners will be notified by May. Applicants and their research projects may be based anywhere in the world. Applications must be in English.

Closing Date: March 1st

Contributor: The scholarship is funded by the royalties from Feminist Criminology, an innovative journal that is dedicated to research related to women, girls, and crime within the context of a feminist critique of criminology

Additional Information: Feminist Criminology is published quarterly by SAGE Publications as the official journal of the Division on Women and Crime (DWC) of the American Society of Criminology. This international publication focuses on research and theory that highlights the gendered nature of crime. For more information, please visit http://fcx.sagepub.com/.

\section{Shuttleworth Fellowship Program for International Fellows}

Purpose: The Shuttleworth Foundation is offering Fellowships to individuals with innovative ideas on social change, especially at the intersection of 'openness, technology, knowledge and learning'. Type: Fellowship

Value: The value of the award is equivalent to a year's salary, based on the Fellow's qualifications and experience, as well as access to travel allowance. In addition, the Fellow will have access to further project funding from the Foundation

Length of Study: 1 year, with the possibility of extension

Closing Date: March 1st or September 1st

Additional Information: For further information, please contact fellowships@shuttleworthfoundation.org.

\section{Turkiye Burslari Scholarship}

Eligibility: The Turkish government is inviting applications from international (non-Turkish) students for the Turkiye Burslari graduate scholarship program, to pursue a Master's or a Phd degree at a Turkish University.

Type: Scholarship

Value: The award provides a monthly stipend (US $\$ 300$ for Master's and US\$400 for PhD students per month) in addition to covering your tuition, health insurance and residence in a public university dormitory Length of Study: 1 year

Application Procedure: The online application is typically due in March.

Closing Date: March

Additional Information: Türkiye Scholarship Students take Turkish language course for 1 year if they do not have proof of Turkish Language knowledge. Please refer to the website for more details: www.turkiyeburslari.gov.tr/index.php/en/turkiye-burslari/bursolanaklari.

\section{SIDNEY SUSSEX COLLEGE}

Cambridge University, Sidney Street, Cambridge, CB2 3HU, England

Tel: (44) 1223338800

Fax: (44) 1223338884

Email: gradtutor@sid.cam.ac.uk

Website: www sid cam ac.uk

Contact: Sidney Sussex College Tutor for Graduate Students

Founded in 1596, Sidney Sussex College admits men and women as undergraduates and graduates. The college presently has approximately 200 graduate students, including about 100 working for the $\mathrm{PhD}$ degree. The college has excellent sporting, dramatic and musical facilities.

\section{Evan Lewis-Thomas Law Studentships}

Subjects: Law and cognate subjects.

Purpose: To support students carrying out research or taking advanced courses.

Eligibility: There are no eligibility restrictions. Candidates must have shown proficiency in Law and Jurisprudence, normally by obtaining a university degree in Law by August, and they must be or become candidates for the PhD Degree, the Diploma in Legal Studies, the Diploma in International Law, the MPhil Degree (1 year course) in Criminology, or the LL.M Degree. Students from other Cambridge Colleges may apply, but if successful they would be expected to transfer their membership to Sidney Sussex College. In the competition for the studentship, no preference will be given to candidates who nominate Sidney Sussex College as their college of first or second choice on their application form.

Level of Study: Postgraduate, Doctorate

Type: Scholarship

Value: Up to $£ 12,000$ to match with funds administered centrally by the UCAM

Length of Study: 1-3 years

Study Establishment: The University of Cambridge

Country of Study: United Kingdom

No. of awards offered: Up to 2

Application Procedure: Sidney Sussex is implementing a new online application process. Please refer to the website www.sid.cam.ac.uk/ postgrads/scholarships.

Closing Date: April 1st

Funding: Private

Contributor: Sidney Sussex College

Additional Information: For further information contact the Tutor for Graduate Students at gradtutor@sid.cam.ac.uk.

\section{The Gledhill Research Studentship}

Subjects: All subjects.

Purpose: To provide full support for research leading to a PhD degree.

Eligibility: Applicants must apply for a postgraduate place at the University of Cambridge. Students from other Cambridge colleges may apply, but if successful they would be expected to transfer their membership to Sidney Sussex College. In the competition for the studentship, no preference will be given to candidates who nominate Sidney Sussex as their college of first or second choice on their application form.

Level of Study: Doctorate

Type: Studentship

Value: Up to $£ 12,000$ to match with funds administered centrally by the UCAM

Length of Study: 3 years

Study Establishment: The University of Cambridge

Country of Study: United Kingdom

No. of awards offered: Up to 2

Application Procedure: Sidney Sussex is implementing a new online application process. Please see the college's website www.sid.cam. ac.uk/postgrads/scholarships for further details.

Closing Date: April 1st

Funding: Private

Contributor: Sidney Sussex College

Additional Information: For further information contact the Tutor for Graduate Students. Check website: www.sid.cam.ac.uk/current/ postgrads/scholarships for further details. 


\section{For further information contact:}

Email: gradtutor@sid.cam.ac.uk

Website: www.sid.cam.ac.uk/current/postgrads/scholarships/

GledhillStudentship.html

\section{THE SIEVERT LARSSON FOUNDATION}

Box 23415, CY-1683 Nicosia, Cyprus

Email: info@sievertlarssonscholarships.org

Contact: The Sievert Larsson Scholarship Foundation

The Sievert Larsson Scholarship Foundation's primary purpose is to facilitate the education of promising students from disadvantaged backgrounds. The Foundation will also facilitate the education of a few high calibre students that have exhibited excellence through their academic achievements.

\section{The Sievert Larsson Scholarship}

Purpose: To support students who come from financially vulnerable homes and who would not otherwise have the opportunity to study in Sweden.

Level of Study: Postgraduate

Type: Scholarship

Value: Version 1: Full tuition fee waiver (covers 100 per cent of the tuition fees) during the 2-year programme (4 semesters). Version 2: Full tuition fee waiver (covers 100 per cent of the tuition fees) and 230,000 SEK for cost of living during the 2-year programme (4 semesters)

Length of Study: 2 years

Study Establishment: Chalmers University of Technology

Country of Study: Thailand

Application Procedure: Applications for the Sievert Larsson

Scholarship are made online via the Chalmers scholarship application form.

Closing Date: January 16th

Contributor: The Sievert Larsson Foundation

\section{SIGMA THETA TAU INTERNATIONAL}

\author{
550 West North Street, Indianapolis, IN, 46202, \\ United States of America \\ Tel: (1) 8886347575 \\ Fax: (1) 3176348188 \\ Email: research@stti.iupui.edu \\ Website: www.nursingsociety.org \\ Contact: Tonna M. Thomas, Grants Coordinator
}

Sigma Theta Tau International exists to promote the development dissemination and utilization of nursing knowledge. It is committed to improving the health of people worldwide through increasing the scientific base of nursing practice. In support of this mission, the society advances nursing leadership and scholarship, and furthers the utilization of nursing research in healthcare delivery as well as in public policy.

\section{Doris Bloch Research Award}

Subjects: Nursing.

Purpose: To encourage qualified nurses to contribute to the advancement of nursing through research. Multidisciplinary and international research is encouraged.

Eligibility: Applicants must be a registered nurse with a current licence, must have received a Master's degree, must have submitted an application package, must be ready to start the research project and must have signed a Sigma Theta Tau International research agreement. Allocation of funds is based on the quality of the proposed research, the future promise of the applicant and the applicant's research budget. Applications from novice researchers who have received no other national research funds are encouraged and will receive preference for funding, other aspects being equal.

Level of Study: Doctorate, Postdoctorate, Postgraduate, Predoctorate, Master's prepared

Type: Research grant

Value: Up to US $\$ 5,000$
Frequency: Annual

Country of Study: Any country

No. of awards offered: 1

Application Procedure: All applications must be submitted via the online submission system. A link to the submission system will be available in April.

Closing Date: December 1st

Funding: Private

Contributor: Sigma Theta Tau International

No. of awards given last year: 1

Additional Information: Please see the website for further details www.nursingsociety.org/Research/Grants/Pages/grant_bloch.aspx.

\section{Rosemary Berkel Crisp Research Award}

Subjects: Women's health, oncology and infant or child care.

Purpose: To support nursing research in the critical areas of women's health, oncology and pediatrics.

Eligibility: Open to registered nurses with a current licence who have a Master's or higher degree (those with baccalaureate degrees may be co-investigators), have submitted a complete research application package, are ready to initiate the research project and are Sigma

Theta Tau International members. Some preference is given to applicants residing in Illinois, Missouri, Arkansas, Kentucky and Tennessee. See website www.nursingsociety.org.

Level of Study: Doctorate, Postdoctorate, Postgraduate, Predoctorate, Master's prepared

Type: Research award

Value: US $\$ 5,000$

Frequency: Annual

Country of Study: Any country

No. of awards offered: 1

Application Procedure: All applications must be submitted via the online application system. See www.nursingsociety.org for information.

Closing Date: December 1st

Funding: Private

Contributor: The Harry L Crisp II and Rosemary Berkel Crisp

Foundation to Sigma Theta Tau International's Research Endowment No. of awards given last year: 1

Additional Information: The allocation of funds is based on a research project in the area of women's health, oncology or paediatrics that is ready for implementation, the quality of the proposed research, future potential of the application, appropriateness of the research budget and feasibility of the time frame. Please see the website for further details www.nursingsociety.org/Research/Grants/ Pages/grant_crisp.aspx.

\section{Sigma Theta Tau International Small Research Grants} Subjects: Nursing.

Purpose: To encourage nurses to contribute to the advancement of nursing through research.

Eligibility: Open to registered nurses with a current licence who have submitted a complete research application package, have a project ready for implementation, hold a Master's degree, are enroled in a doctoral programme and have signed a Sigma Theta Tau International research agreement. Check website for details.

Level of Study: Doctorate, Postdoctorate, Postgraduate, Master's prepared

Type: Research grant

Value: Up to US\$5,000

Frequency: Annual

Country of Study: Any country

No. of awards offered: $10-15$

Application Procedure: All applications must be submitted via the online application system. See www.nursingsociety.org for information. A link to the submission system will be available in July.

Closing Date: December 1st

Funding: Foundation, private

No. of awards given last year: 10-15

Additional Information: This grant has no specific focus; however multidisciplinary, historical and international research is encouraged. The funding date is June 1st. Please see the website for further details www.nursingsociety.org/Research/Grants/Pages/ small_grants.aspx. 


\section{Sigma Theta Tau International/Alpha Eta Collaborative} Research Grant

Subjects: Nursing

Purpose: To provide a research grant to Tau Lambda@Large chapter members for a new research project in Africa.

Eligibility: The applicant must be a member of the Tau Lambda@ Large residing in Africa, must submit online a completed research application package and a signed research agreement, and should be ready to implement the research project when funding is received. The applicant should also submit a completed abstract to the Virginia Henderson International Nursing Research Library and credit grant research partners in all publications and presentations of the research, and a final report.

Level of Study: Postgraduate, Doctorate, Postdoctorate

Type: Research grant

Value: Up to US $\$ 2,000$

Frequency: Annual

Country of Study: Africa

No. of awards offered: 1

Application Procedure: All applications must be submitted through the online submission system. See the website www.nursingsociety. org for information.

Closing Date: December 1st

Funding: Private

Contributor: Alpha Eta chapter of Sigma Theta Tau International

No. of awards given last year: 1

Additional Information: Please see the website for further details www.nursingsociety.org/Research/Grants/Pages/AlphaEta.aspx.

\section{Sigma Theta Tau International/American Association of Critical Care Nurses}

Subjects: Critical care nursing practice.

Purpose: To encourage qualified nurses to contribute to the advancement of nursing through critical care nursing practice research.

Eligibility: Open to registered nurses with a current licence who have received a Master's degree and submitted a grant proposal relevant to critical care nursing practice. Research must be related to critical care nursing practice.

Level of Study: Postgraduate, Doctorate, Postdoctorate, Predoctorate, Master's prepared

Type: Research grant

Value: Up to US $\$ 10,000$

Frequency: Annual

Country of Study: Any country

No. of awards offered: 1

Application Procedure: For application please contact the American Association of Critical Care Nurses, Department of Research.

Closing Date: November 1st

Funding: Private, foundation

Contributor: The American Association of Critical Care Nurses and

Sigma Theta Tau International

Additional Information: January 1st is the funding date.

\section{For further information contact:}

American Association of Critical Care Nurses, Department of Research, 101 Columbia, Aliso Viejo, CA, 92656-1491, United States of America

Tel: (1) 9493622000

Fax: (1) 9493622020

Website: www.aacn.org/grants

\section{Sigma Theta Tau International/American Association \\ of Diabetes Educators Grant}

Subjects: Diabetes education and care.

Purpose: To encourage qualified nurses to contribute to the enhancement of and availability of quality through diabetes education and care through nursing research.

Eligibility: The applicant must be a registered nurse but team members may be from other disciplines. The principal investigator must also have received a Master's degree, and have the ability to complete the project in 1 year from the funding date. Preference will be given to Sigma Theta Tau International members, other qualifications being equal. The grant must be dedicated to diabetes education and care research.
Level of Study: Postgraduate, Doctorate, Postdoctorate, Predoctorate, Master's prepared

Type: Research grant

Value: Up to US $\$ 6,000$

Frequency: Annual

Country of Study: Any country

No. of awards offered: 1

Application Procedure: For application please contact American Association of Diabetes Educators (AADE).

Closing Date: October 1st

Funding: Foundation, private

Contributor: The American Association of Diabetes Educators and Sigma Theta Tau International

Additional Information: January 1st is the funding date. Please check at website for more information.

For further information contact:

AADE Foundation Grants, 200 West Madison Street, Suite 800,

Chicago, IL, 60606, United States of America

Tel: (1) 8003383633

Fax: (1) 3124242427

Website: www.diabeteseducator.org/Foundation/Grants

\section{Sigma Theta Tau International/American Nurses \\ Foundation Grant}

Subjects: Any clinical topic.

Purpose: To encourage the research career development of nurses through the support of research conducted by beginning nurse researchers, or experienced nurse researchers who are entering a new field of study.

Eligibility: Open to registered nurses with a current licence and a Master's degree who have submitted a complete research application package, are ready to start the research project and have signed a Sigma Theta Tau International Research agreement. Preference will be given to Sigma Theta Tau International members, other qualifications being equal.

Level of Study: Doctorate, Postdoctorate, Postgraduate, Predocto-

rate, Master's prepared

Type: Research grant

Value: Up to US $\$ 7,500$

Frequency: Annual

Country of Study: Any country

No. of awards offered:

Application Procedure: Applicants must write for an information booklet and application form. Proposals should be sent to the Sigma Theta Tau International headquarters in even-numbered years (for which applicants should use the Sigma Theta Tau International application), and to the American Nurses Foundation in oddnumbered years (for which applicants should use the American Nurses Foundation application)

Closing Date: May 1st

Funding: Foundation, private

Contributor: The American Nurses Foundation (ANF) and Sigma

Theta Tau International

No. of awards given last year: 1

Additional Information: Allocation of funds is based on the quality of the proposed research, the future promise of the applicant and the applicant's research budget. October is the funding month. Please check at website for more information.

For further information contact:

8515 Georgia Avenue, Suite 400 West, Silver Spring, MD, United States of America

Tel: (1) 3016285227

Website: www.nursingsociety.org/Research/Grants/Pages/grant_anf aspx

\section{Sigma Theta Tau International/Association of Nurses in} AIDS Care Grant

Subjects: HIV prevention, symptom management, promotion of selfcare and adherence.

Purpose: To encourage research career development of nurses through support of clinically oriented HIV/AIDS research and increase the number of HIV studies being done by nurses. 
Eligibility: Open to candidates who have obtained a master' degree and/or are enroled in a doctoral programme, must be a registered nurse with current license. For further information please see the website.

Level of Study: Research

Type: Grant

Value: $\$ 2,500$

Length of Study: 1 year

Frequency: Annual

No. of awards offered: 1

Application Procedure: All applications must be submitted via the online submission system. See website www.nursingsociety.org for information.

Closing Date: April 1st

Contributor: ANAC and Sigma Theta Tau International

No. of awards given last year: 1

Additional Information: Please see the website for further details www.nursingsociety.org/Research/Grants/Pages/anac_grant.aspx.

\section{Sigma Theta Tau International/Association of}

\section{Perioperative Registered Nurses Foundation Grant}

Subjects: Perioperative nursing practice.

Purpose: To encourage nurses to conduct research related to perioperative nursing practice and contribute to the development of perioperative nursing science.

Eligibility: Applicants must be a registered nurse with a current license in the perioperative setting, or a registered nurse who demonstrates interest in or significant contributions to nursing practice. The principal investigator must have, as a minimum, a Master's degree in nursing. Applicants must submit a completed Association of Perioperative Registered Nurses (AORN) research application. Membership of either organization is acceptable, but not required.

Level of Study: Doctorate, Postdoctorate, Postgraduate, Predoctorate, Master's prepared

Type: Research grant

Value: US $\$ 5,000$. Allocation of funds is based on the quality of the research, the future promise of the applicant and the applicant's research budget

Frequency: Annual

Country of Study: Any country

No. of awards offered: 1

Application Procedure: Applicants must write to the AORN for an application form and general instructions.

Closing Date: April 1st

Funding: Foundation, private

Contributor: The Association of Perioperative Registered Nurses and Sigma Theta Tau International

No. of awards given last year: 1

Additional Information: July is the funding month. Please check at website for more information.

\section{For further information contact:}

Association of Perioperative Registered Nurses (AORN), 2170 South Parker Road, Suite 400, Denver, CO, 80231-571, United States of America

Tel: (1) 8007552676 ext. 207

Fax: (1) 3037502927

Email: Ispruce@aorn.org

Website: www.nursingsociety.org/Research/Grants/Pages/

grant_aorn.aspx

Contact: Lisa Spruce

\section{Sigma Theta Tau International/Canadian Nurses \\ Foundation Grant}

Subjects: Nursing care.

Purpose: To support research on nursing care issues and build nursing research capacity.

Eligibility: (i) Must be a practicing Canadian registered nurse with a current license; (ii) research must address at least one of the following nursing care practice priorities: supporting research that takes place in 'clinical' settings, where nurses provide care, including the community setting; supporting research that involves novice researchers; supporting research teams that are interdisciplinary; supporting research that is 'national', involving all provinces and research that involves under-resourced areas within all provinces; (iii) be an active member of Sigma Theta Tau International; (iv) submission of completed research application via STTI's online submission system must be completed by December 1st; (v) highest reviewed submission will be forwarded to CNF for further funding consideration.

Level of Study: Research

Type: Grant

Value: Up to $\$ 5,000$

No. of awards offered: 1

Application Procedure: All applications must be submitted via the online submission system. A link to the submission system will be available in mid-July.

Closing Date: December 1st

Contributor: Canadian Nurses Foundation and Sigma Theta Tau International

Additional Information: Applicants must be a practicing Canadian registered nurse with a current license to apply. Please see the website for further details www.nursingsociety.org/Research/Grants/ Pages/grant_cnf.aspx.

\section{Sigma Theta Tau International/Emergency Nurses Association Foundation Grant}

Subjects: Topics relating to the specialized practice of emergency nursing. All relevant subjects will be considered, although priority will be given to studies that relate to the Association's Research Initiatives, which include, but are not limited to, mechanisms to assure effective, efficient and quality emergency nursing care delivery systems, factors affecting healthcare cost, productivity and market forces to emergency services, ways to enhance health promotion and injury prevention, and mechanisms to assure quality and cost-effective educational programmes for emergency nursing.

Purpose: To encourage nursing research that will advance the specialized practice of emergency nursing.

Eligibility: Applicants must be a registered nurse, but team members may be from other disciplines. Applicants must have a Master's degree, submit a complete application with signed research agreement and be ready to or have already started the research project.

See website www.nursingsociety.org

Level of Study: Doctorate, Postdoctorate, Postgraduate, Predoctorate, Master's prepared

Type: Research grant

Value: Up to US $\$ 6,000$

Frequency: Annual

Country of Study: Any country

No. of awards offered: 1

Application Procedure: For application please contact Emergency Nurses Association (ENA) Foundation.

Closing Date: March 1st

Funding: Foundation, private

Contributor: The Emergency Nurses Association Foundation and

Sigma Theta Tau International

No. of awards given last year: 1

Additional Information: August is the funding date.

\section{For further information contact:}

Emergency Nurses Association (ENA) Foundation, 915 Lee Street, Des Plaines, IL, 60016-6569, United States of America

Tel: (1) 8474604100

Fax: (1) 8474604005

Website: www.ena.org/foundation

\section{Sigma Theta Tau International/Hospice and Palliative} Nurses Foundation Grant

Subjects: Hospice and palliative care nursing

Purpose: To encourage qualified nurses to contribute to the advancement of nursing care through research.

Eligibility: Open to candidates who have obtained a Master's or Doctoral degree or are enroled in a doctoral programme. The candidate must be a registered nurse with current license and must sign a research grant agreement. For further information please see the website.

Level of Study: Postgraduate, Predoctorate, Doctorate, Postdoctorate, Master's prepared

Type: Research grant

Value: Up to US $\$ 10,000$ 
Frequency: Annual

No. of awards offered: 1

Application Procedure: All applications must be submitted via the online submission system. See website for further information.

Closing Date: April 1st

Funding: Foundation, private

Contributor: Sigma Theta Tau International and the Hospice and

Palliative Nurses Foundation

No. of awards given last year: 1

Additional Information: The funding date is August 1st. Please see the website for further details www.nursingsociety.org/Research/

Grants/Pages/grant_hpna.aspx.

\section{Sigma Theta Tau International/Joan K. Stout, RN,} Research Grant

Subjects: Nursing

Purpose: To advance ongoing evidence-based study by nurse researchers on the impact of the practice of simulation education in schools of nursing and clinical care settings.

Eligibility: The applicant should be a registered nurse with a current license, have a Master's degree or be enroled in a doctoral program. The applicant should be ready to implement the research project when funding is received, complete the project within 1 year of funding, submit a completed abstract to the Virginia Henderson International Nursing Research Library and a final report to Sigma Theta Tau International.

Level of Study: Postgraduate, Predoctorate

Type: Research grant

Value: Up to $\$ 5,000$

Frequency: Annual

Country of Study: Any country

No. of awards offered: 1

Application Procedure: A completed research application must be submitted through the online submission system. See website for information.

Closing Date: July 1st

Funding: Foundation

Contributor: Sigma Theta Tau International Foundation

No. of awards given last year: 1

Additional Information: Please see the website for further details www.nursingsociety.org/Research/Grants/Pages/JoanKStout.aspx.

\section{Sigma Theta Tau International/Midwest Nursing Research Society Research Grant}

Subjects: Multi-disciplinary, historical and international research.

Purpose: To encourage qualified nurses to contribute to the advancement of nursing through research.

Eligibility: Open to candidates who have obtained a master's degree and/or are enroled in a doctoral programme. The candidate must also be a registered nurse with current license and be a Midwest Nursing Research Society and a honor society member in good standing. For further information please see the website.

Level of Study: Postgraduate, Predoctorate, Doctorate, Postdoctorate, Master's prepared

Type: Research grant

Value: Up to US $\$ 2,500$

Frequency: Annual

No. of awards offered: 1

Application Procedure: All applications must be submitted via the online submission system. See website for information.

Closing Date: April 1st

Funding: Foundation, private

Contributor: Sigma Theta Tau International and the Midwest Nursing Research Society

No. of awards given last year: 1

Additional Information: The funding date is August 1st. Please see the website for further details www.nursingsociety.org/Research/ Grants/Pages/grant_mnrs.aspx.

\section{Sigma Theta Tau International/National League for Nursing Grant (NLN)}

Subjects: Nursing.

Purpose: To support research that advances the science of nursing education and learning through the use of technology in dissemination of knowledge.
Eligibility: The applicant must be a registered nurse with a current license, hold a master's or doctoral degree or be enrolled in a doctoral program. The applicant must complete a project within 1 year of funding and must sign a Research Grant Agreement. Preference wil be given to Sigma Theta Tau International and National League for Nursing members.

Level of Study: Doctorate, Postdoctorate, Postgraduate,

Predoctorate

Type: Grant

Value: Up to US $\$ 5,000$

Country of Study: Any country

No. of awards offered: 1

Application Procedure: All applications must be submitted via the online submission system. See website for information.

Closing Date: June 1st

Funding: Individuals

No. of awards given last year: 1

Additional Information: Funding date is November 1st. Please see the website for further details www.nursingsociety.org/Research/ Grants/Pages/grant_nln.aspx.

\section{Sigma Theta Tau International/Oncology Nursing Society Foundation Grant}

Subjects: Clinical oncology.

Purpose: To simulate clinically related oncology nursing research. Eligibility: Open to registered nurses who are actively involved in some aspect of cancer patient care, education or research and hold a Master's degree. Preference will be given to Sigma Theta Tau members, other qualifications being equal.

Level of Study: Doctorate, Postdoctorate, Postgraduate, Predoctorate, Master's prepared

Type: Research grant

Value: Up to US $\$ 25,000$

Frequency: Annual

Country of Study: Any country

No. of awards offered: 1

Application Procedure: Applicants must send proposals for this grant to the Oncology Nursing Society.

Closing Date: October 1st

Funding: Foundation, private

Contributor: The Oncology Nursing Society and Sigma Theta Tau International

Additional Information: The funding date is January 1st. Please check website or contact the organization for more details.

\section{For further information contact:}

Oncology Nursing Foundation, 125 Enterprise Drive, Pittsburgh, PA, 15275, United States of America

Tel: (1) 4128596100

Fax: (1) 4128596162

Website: www.ons.org

\section{Sigma Theta Tau International/Rehabilitation Nursing}

\section{Foundation Grant}

Subjects: Rehabilitation nursing.

Purpose: To encourage research related to rehabilitation nursing. Eligibility: The applicant must be a registered nurse in rehabilitation or a registered nurse who demonstrates interest in and significantly contributes to rehabilitation nursing. Proposals that address the clinical practice, educational or administrative dimensions of rehabilitation nursing are requested. Quantitative and qualitative research projects will be accepted for review. The principal investigator must have a Master's degree in nursing and an ability to complete the project within 2 years of initial funding.

Level of Study: Postdoctorate, Doctorate, Postgraduate, Predoctorate, Master's prepared

Type: Research grant

Value: Up to US $\$ 4,500$

Frequency: Annual

Country of Study: Any country

No. of awards offered: 1

Application Procedure: Applicants must write to the Rehabilitation Nursing Foundation for details.

Closing Date: March 1st

Funding: Private, foundation 
Contributor: The Rehabilitation Nursing Foundation and Sigma Theta Tau International

Additional Information: The funding month is the following January.

For further information contact:

Rehabilitation Nursing Foundation, 4700 West Lake Avenue, Glenview, IL, 60025, United States of America

Tel: (1) 8473754710

Fax: (1) 8473754710

Email: info@rehabnurse.org

Website: www.rehabnurse.org/research/researchgrants.html

\section{Sigma Theta Tau International/Southern Nursing Research Society Grant}

Subjects: Nursing.

Purpose: To encourage qualified nurses to contribute to the advancement of nursing through research. Proposals for pilot and/or development research may be submitted for this grant.

Eligibility: The applicant must be a registered nurse with a current license, hold at the minimum a Master's degree or its equivalent and/ or be enroled for a doctoral program, and be a member in good standing of both the STTI and SNRS. He or she must submit online a completed research application package and a signed research agreement, and should be ready to implement the research project when funding is received; however, the research may not be conducted as part of an academic degree. The applicant should also submit a completed abstract to STTI's Virginia Henderson International Nursing Research Library, an abstract for publication to SNRS, and credit grant research partners in all publications and presentations of the research, and a final report to STTI.

Level of Study: Postgraduate, Predoctorate

Type: Research grant

Value: Up to US $\$ 5,000$

Frequency: Annual

Country of Study: Any country

No. of awards offered: 1

Application Procedure: All applications must be submitted via the online submission system. See the website for information.

Closing Date: April 1st

Funding: Foundation

Contributor: Sigma Theta Tau International Foundation and Southern Nursing Research Society

No. of awards given last year: 1

Additional Information: Please see the website for further details www.nursingsociety.org/Research/Grants/Pages/stti_snrs.aspx.

\section{Sigma Theta Tau International/The Council for the Advancement of Nursing Science \\ Subjects: Nursing.}

Purpose: To encourage qualified nurses to improve the health of the world's people through research. Proposals for clinical, educational or historical research, including plans for disseminating the research findings, may be submitted for the grant.

Eligibility: Preference will be given to a Sigma Theta Tau International member who holds at the minimum a Master's degree or its equivalent. He or she must submit online a completed research application package and should be ready to implement the research project when funding is received. The applicant should also submit a completed abstract to STTI's Virginia Henderson International Nursing Research Library, a completed project abstract for presentation to the Sigma Theta Tau International or the Council for the Advancement of Nursing Science, and credit grant research partners in all publications and presentations of the research.

Level of Study: Postgraduate, Predoctorate

Type: Research grant

Value: Up to $\$ 5,000$

Frequency: Annual

Country of Study: Any country

No. of awards offered: 1

Application Procedure: Applicants must submit applications via the online submission system. See the website www.nursingsociety.org for information.

Closing Date: July 1st

Funding: Foundation
Contributor: Sigma Theta Tau International Foundation and The Council for the Advancement of Nursing Science

No. of awards given last year: 1

Additional Information: Applicants must be a member in good standing of both STTI and CANS.

\section{Sigma Theta Tau International/Virginia Henderson Clinical Research Grant \\ Subjects: Clinical research.}

Purpose: To encourage the research career development of clinically based nurses through support of clinically orientated research. Eligibility: Open to registered nurses actively involved in some aspect of healthcare delivery, education or research in a clinical setting, who are Theta Tau International members, hold a Master's degree in nursing or are enroled in a doctoral programme. The allocation of funds is based on a research project ready for implementation, the quality of the proposed research, the future potential of the applicant, appropriateness of the research budget and feasibility of the time frame.

Level of Study: Doctorate, Postdoctorate, Postgraduate, Predoctorate, Master's prepared

Type: Research grant

Value: US $\$ 5,000$

Frequency: Every 2 years

Country of Study: Any country

No. of awards offered: 1

Application Procedure: All applications must be submitted via the online submission system.

Closing Date: December 1st in odd-numbered years

Funding: Private

Contributor: The Virginia Henderson Clinical Research Endowment Fund

Additional Information: June 1st is the funding month. Please see the website for further details www.nursingsociety.org/Research/

Grants/Pages/grant_VHL.aspx.

\section{Sigma Theta Tau International/Western Institute of Nursing Research Grant \\ Subjects: Nursing. \\ Purpose: To encourage qualified nurses to contribute to the} advancement of nursing through research.

Eligibility: Open to a registered nurse with a current license, who has a master's degree and/or is enrolled in a doctoral programme. The applicant must be a member of Western Institute of Nursing and Sigma Theta Tau International.

Level of Study: Postgraduate, Predoctorate, Doctorate, Postdoctorate, Master's prepared

Type: Grant

Value: Up to US $\$ 2,500$

Frequency: Annual

Country of Study: Any country

No. of awards offered: 1

Application Procedure: All applications must be submitted via the online submission system.

Closing Date: December 1st

Funding: Foundation

Contributor: Sigma Theta Tau International and the Western Institute of Nursing

Additional Information: The funding date is April 1st. Please see the website for further details www.nursingsociety.org/Research/Grants/ Pages/grant_win.aspx.

\section{SILVERHILL INSTITUTE OF ENVIRONMENTAL RESEARCH AND CONSERVATION}

60 Adelaide Street East, Suite 501, Toronto, ON, M5C 3E4, Canada Email: peter@silverhillinstitute.com Website: www.silverhillinstitute.com Contact: Dr Peter Homenuck, RPP

The Silverhill Institute of Environmental Research and Conservation was established as a charitable foundation in 2004. This foundation was established according to the Canada Corporations Act. It 
supports demonstration projects to develop, maintain and preserve wood lots. It also supports wetland protection and restoration as means for conservation and contributing to diversity and the protection of groundwater and surface water resources, and carries out research on environmental issues of the day.

\section{Silverhill Institute of Environmental Research and Conservation Award}

Subjects: Geography, environmental studies, ecology, biology, natural resources, planning, forestry and water resources.

Purpose: To financially support students for thesis/research projects that have an applied environmental or conservation focus and that have the potential to contribute in a direct way to society and/or provide specific community benefit.

Eligibility: Open only to graduate students for research (thesis or major paper) that is applied in nature and can be demonstrated to have community benefit or applicability.

Level of Study: Research, Postgraduate

Type: Grant

Value: Canadian $\$ 2,500$ for the Summer season. Smaller awards of $\$ 500$ are also available

Frequency: Annual

Study Establishment: University of Manitoba

Country of Study: Canada

No. of awards offered: Varies

Application Procedure: Download the grant application form in PDF or Word format and return the completed form by the due date. Closing Date: February 28th

Additional Information: The grant will be paid out as follows: Canadian $\$ 2,500$ upon selection and Canadian $\$ 1,000$ upon receipt of a copy of the finished theses/product. Please see the website for further details.

\section{SIMON FRASER UNIVERSITY}

\author{
8888 University Drive, Burnaby, BC, V5A 1S6, Canada \\ Tel: (1) 7787823708 \\ Fax: (1) 7787824920 \\ Email: pchhina@sfu.ca \\ Website: www.business.sfu.ca \\ Contact: Ms Preet Virk, Manager, Donor Relations
}

Named after explorer Simon Fraser, SFU opened on September 9 , 1965. Taking only 30 months to grow from the idea stage into an almostcompleted campus with 2,500 students it was dubbed the 'Instant University'. The original campus has grown into three vibrant campuses in Burnaby, Vancouver and Surrey and SFU's reputation has grown into one of the innovative teaching, research, and community outreach.

\section{Joseph-Armand Bombardier Canada Graduate Scholarships (CGS) Master's Program}

Subjects: All subjects.

Purpose: Seeks to develop the research skills and assist in the training of highly qualified personnel by supporting students in the social sciences and humanities.

Eligibility: Open to those pursuing a first Graduate Degree. Be a citizen or permanent resident of Canada.

Level of Study: Graduate

Type: Scholarship

Value: $\$ 17,500$ per year

Length of Study: 1 year

Frequency: Annual

Application Procedure: See the website.

Closing Date: Early November

Additional Information: Please see the website for further details

\section{Methanex Graduate Scholarship in International \\ Marketing}

Subjects: International business and marketing.

Purpose: To recognize and reward an outstanding student pursuing an MBA at the Segal Graduate School of Business.

Eligibility: Open to a student with a demonstrated focus on

international business and marketing.

Level of Study: Graduate

Type: Scholarship
Value: $\$ 5,000$

Frequency: Annual

Study Establishment: Segal Graduate School of Business

Country of Study: Canada

No. of awards offered: 1

Application Procedure: Check website for further information.

Applications are accepted in January.

Closing Date: January 30th

Additional Information: Please see the website for further details http://beedie.sfu.ca/mba/apply/scholarships.php.

\section{NSERC Industrial Post-Graduate Scholarships (IPS)}

Subjects: Science and engineering.

Purpose: To encourage scholars to consider research careers in industry.

Eligibility: Open to highly qualified science and engineering graduates.

Level of Study: Graduate

Type: Scholarship

Value: $\$ 15,000$ per year for up to 2 years plus company contribution of $\$ 6,000$ minimum per year

Length of Study: Up to 2 years

Frequency: Annual

Country of Study: Canada

Application Procedure: Check website for further details.

Closing Date: Apply at any time (check details in website)

For further information contact:

Office of the Dean of Graduate Studies

Email: dcoburn@sfu.ca

Website: www.sfu.ca/dean-gradstudies/blog/scholarships/NSERCIPS.html

Contact: Deena Coburn, Director, Administrative Services

\section{NSERC/MITACS Joint Industrial Postgraduate}

Scholarship (IPS)

Subjects: Mathematics.

Eligibility: Open to any graduate student in Simon Fraser University (SFU) using mathematics in their research.

Level of Study: Doctorate, Postgraduate, Graduate

Type: Scholarship

Value: $\$ 22,500$

Length of Study: Up to 3 years

Frequency: Annual

Study Establishment: Simon Fraser University (SFU)

Country of Study: Canada

Application Procedure: Check website address for further details. Closing Date: Check with website

\section{Peter Legge Graduate Volunteer Leadership Award in \\ Business}

Subjects: Business administration.

Purpose: To provide financial support for graduate students pursuing or entering a degree at the Segal Graduate School of Business.

Eligibility: Open to graduate students pursuing a degree at the Segal Graduate School of Business.

Level of Study: Graduate

Type: Award

Value: $\$ 4,100$

Frequency: Annual

Study Establishment: Segal Graduate School of Business

Country of Study: Bulgaria

Application Procedure: Check the website for further details www. sfu.ca/dean-gradstudies/awards/privateawards/all-awards/legge.html. Closing Date: May 31st

Additional Information: Candidates must include the application for Private Graduate Scholarship along with the application, curriculum vitae, cover letter, and letter of reference.

\section{Phi Theta Kappa International Summit Scholarships}

Subjects: All subjects.

Eligibility: Open to Phi Theta Kappa members with a minimum 3.75 Grade Point Average and have completed 30 credit hours.

Level of Study: Graduate 
Type: Scholarship

Value: Canadian $\$ 3,500$

No. of awards offered: Up to 3

Application Procedure: Candidates must apply through the website and also mail a package containing paper application form, original or photocopied, a one-page summary of achievements and activities, a copy of recent college transcript, and a copy of Phi Theta Kappa certificate of membership.

Closing Date: April 30th (for fall term), September 30th (for spring term), or January 31 st (for summer term)

Additional Information: Students applying from outside Vancouver's Lower Mainland area may be eligible for a travel allowance of $\$ 500-1,000$. Part-time students and students with a previous bachelor degree are not eligible.

\section{Postdoctoral Fellowship in Sustainable Energy Technology}

Subjects: The fellowship is awarded in Sustainable Energy Technology, Behavior and Policy.

Eligibility: Applications from recent PhD's seeking to develop (or continuing to develop) research careers relating to sustainable energy technology, behavior and policy are invited. A wide range of methodological skills will be considered as assets, including: survey design and analysis, advanced statistical analysis, discrete choice modelling, energy-economy modelling (e.g. optimization, CGE or simulation models), transportation modelling, diffusion modelling, agent-based modelling, social network analysis, qualitative interviews and ethnographic analysis. Canadian applicants are eligible for this postdoctoral fellowship. For detailed information, please check website. Level of Study: Postdoctorate

Type: Fellowship

Value: US $\$ 45,000 /$ Annum - each which can be received to study in CANADA and students from Canada are eligible to apply

Country of Study: Canada

Application Procedure: The mode of applying is electronically. Applicants should send a concise cover letter, curriculum vitae, up to three publications or writing samples and a list of at least three academic references electronically.

Closing Date: Applications will be accepted until the position is filled, applications will be reviewed starting in January

Contributor: The School of Resource and Environmental Management at Simon Fraser University

Additional Information: The start date is flexible, but the position is expected to be 2 years in duration (subject to a 1-year evaluation). Only short-listed candidates will be contacted.

\section{Scotiabank Graduate Scholarship for Women \\ Entrepreneurs \\ Subjects: Business administration.}

Purpose: To provide financial support for a female student enroling for MBA.

Eligibility: Open to academically excellent female students enrolled full or part-time in an MBA program.

Level of Study: Graduate

Type: Scholarship

Value: $\$ 5,000$

Frequency: Annual

Application Procedure: Check website for further details www.sfu.ca/ dean-gradstudies/awards/privateawards/all-awards/scotiabank.html. Closing Date: May 30th

Additional Information: Candidates must submit a cover letter outlining entrepreneurial experience and a letter of reference from a business colleague or faculty member. Preference will be given to a candidate who is, or has been, an entrepreneur, or who plans to study entrepreneurship as part of her degree.

\section{SSHRC Doctoral Fellowships}

Subjects: All subjects.

Purpose: To doctoral support in the humanities and social sciences. Eligibility: Open to those who are currently in attendance at Simon Fraser University.

Level of Study: Postgraduate

Type: Fellowship

Value: $\$ 20,000-35,000$ per year

Length of Study: $1-4$ years
Frequency: Annual

Application Procedure: Check website for further details.

Closing Date: November 2nd

Additional Information: Applications are ranked within subject areas by an SFU committee and recommended applications sent to SSHRC, which announces final results in April or May.

For further information contact:

Website: www.sfu.ca/dean-gradstudies/blog/scholarships/SSHRCdoctoral-2012.html

\section{SSHRC Joseph-Armand Bombardier CGS Doctoral Scholarships}

Subjects: Humanities and social sciences.

Purpose: To provide doctoral support in the humanities and social sciences.

Eligibility: Open to Canadian citizens or permanent residents, who have completed a Master's Degree or at least 1 year of doctoral study and pursuing full time studies leading to a first $\mathrm{PhD}$ or its equivalent. Level of Study: Postgraduate, Predoctorate

Type: Scholarship

Value: $\$ 35,000$ per year

Length of Study: Up to 3 years

Frequency: Annual

Country of Study: Canada

Application Procedure: Candidates can avail information from the Office of the Dean of Graduate Studies, or check the website.

Closing Date: Direct Applications: November 5th and University

Applications: January 8th

Additional Information: The deadline for applications to the appropriate SFU department is approximately October 15th. Please see the website for further details.

\section{TCG International Graduate Scholarship in Business \\ Administration}

Subjects: Business administration.

Purpose: To support for a student in the MBA program.

Eligibility: Open to academically excellent (CGPA > 3.5) graduates.

Preference will be given to a BC resident.

Level of Study: Graduate

Type: Scholarship

Value: $\$ 10,000$

Frequency: Annual

No. of awards offered: 1

Application Procedure: Check website for further details. Applications are accepted in September.

Closing Date: June 30th

Additional Information: Please see the website for further details www.sfu.ca/dean-gradstudies/awards/privateawards/all-awards/tcginternational.html.

\section{Trudeau Foundation Doctoral Scholarship}

Subjects: Social sciences and humanities.

Purpose: To support doctoral students pursuing research in one or more of the four themes: human rights and social justice, responsible citizenship, Canada and the world, and humans and their natural environment.

Eligibility: Open to outstanding students who are in their first or second year of a PhD programme.

Level of Study: Doctorate

Type: Scholarship

Value: $\$ 40,000$ stipend plus $\$ 20,000$ travel allowance

Length of Study: Up to 3 years

Frequency: Annual

Application Procedure: Check website for further details.

Closing Date: November 5th

Additional Information: Research must be in one of the four themes of the foundation. Please see the website for further details www.sfu. ca/dean-gradstudies/blog/scholarships/Trudeau-2012.html.

\section{Vanier Canada Graduate Scholarships (CGS)}

Subjects: All subjects.

Purpose: The CGS Program provides financial support to outstanding eligible students pursuing master's or doctoral studies. 
Eligibility: Open to candidates who are eligible to apply for the NSERC or SSHRC annual competition.

Value: $\$ 50,000$

Length of Study: Up to 3 years

Application Procedure: See the website for details.

Closing Date: September 26th

Contributor: NSERC and SSHRC

Additional Information: Applicants who apply for the NSERC or

SSHRC annual competitions are also considered.

\section{SIR HALLEY STEWART TRUST}

BM Sir Halley Stewart Trust, Cambridge, London, WC1N 3XX,

Tel: (44) 02081440375

Email: email@sirhalleystewart.org.uk

Website: www.sirhalleystewart.org.uk

Contact: Ms Vicky Chant, Secretary to the Trustees

The Sir Halley Stewart Trust has a Christian basis and is concerned with the development of body, mind and spirit, a just environment and international goodwill. The Trust aims to promote innovative research activities or developments.

\section{Sir Halley Stewart Trust Grants}

Subjects: Medical, social or religious projects within certain priority areas.

Purpose: To assist pioneering research and development.

Eligibility: Not open to general appeals, building, capital, running costs or personal education including educational and travel costs. Level of Study: Postgraduate, Research, Doctorate

Type: Grant

Value: Main Grant (usually for salary costs up to circa $£ 60,000$, over a period of up to 3 years), or Small Grant (for no more than $£ 5,000$ as a one-off grant)

Length of Study: $2-3$ years

Frequency: Dependent on funds available

Study Establishment: A U.K. charitable institution, e.g. a hospital, laboratory, university department or charitable organization

Country of Study: Mainly UK but some overseas, Africa (west/south) given priority

Application Procedure: Applicants must contact the Trust for further details. See website: www.sirhalleystewart.org.uk for the application process. Preliminary enquiries available by email/phone call.

Closing Date: Early March

Funding: Private

No. of awards given last year: 37

No. of applicants last year: 441

Additional Information: Further information is available from the Trust's office. The website contains the most up-to-date details. Country of study: mainly UK but some overseas, Africa (west) given priority.

\section{SIR JOHN SOANE'S MUSEUM FOUNDATION}

1040 First Avenue, No. 311, New York, NY, 10022, United States of America

Tel: (1) 2122232012

Fax: (1) 8668411928

Email: info@soanefoundation.com

Website: www.soanefoundation.com

Contact: Charles A Miller-III, Executive Director

The Sir John Soane's Museum Foundation assists the Museum in London to further Soane's commitment to educate and inspire the general and professional public in architecture and the fine and decorative arts. Programmes have attracted students, collectors, architects, decorators and arts enthusiasts since 1991 to its events, lectures, tours and dinners.

\section{Sir John Soane's Museum Foundation Travelling Fellowship \\ Subjects: Art, architecture and the decorative arts.}

Purpose: To enable scholars to pursue research projects related to the work of Sir John Soane's Museum and its collections.
Eligibility: Open to candidates enrolled in a graduate degree programme in a field appropriate to the Foundation's purpose. Level of Study: Graduate, Postgraduate

Type: Fellowship

Value: US $\$ 5,000$

Frequency: Annual

Study Establishment: The choice of the fellowship recipient

Country of Study: Usually the United States of America or the United Kingdom

No. of awards offered: 2

Application Procedure: Applicants must submit a formal proposal of not more than five pages describing the goal, scope and purpose of the research project, in addition to three letters of recommendation.

An interview may be required.

Closing Date: March 1st

Funding: Foundation, private

Contributor: The Board of Directors and the Advisory Board

No. of awards given last year: 2

No. of applicants last year: 30

Additional Information: At the end of each research project the award recipient must submit a written documentation or a sketch book on the progress of the research as outlined in the original proposal with respect to goal, scope and allocation of funds, and give a lecture on the research, arranged by the Foundation. The scholar usually spends some time at Sir John Soane's Museum at 13 Lincoln's Inn Fields, London, studying architectural drawings, models and paintings. Please see the website for further details www.soanefoundation. com/fellowship.html.

\section{SIR RICHARD STAPLEY EDUCATIONAL TRUST}

PO Box 839, Richmond, Surrey, TW9 3AL, England

Email: admin@stapleytrust.org

Website: www.stapleytrust.org

Contact: The Administrator

The Sir Richard Stapley Educational Trust awards grants to graduates studying for higher degrees in the UK without subject restriction, and to graduates studying medicine as a second degree. The grants are to cover shortfall incurred by the payment of tuition fees.

\section{Sir Richard Stapley Educational Trust Grants}

Subjects: Medical, dental and veterinary science and higher degrees in other subjects.

Purpose: To support postgraduate study.

Eligibility: Open to graduates holding a First Class (Honours) degree or a good Second Class (Honours) degree (65 per cent or above, or its overseas equivalent, or a Masters or $\mathrm{PhD}$ ) and who are more than 24 years of age on October 1 st of the proposed academic year. Students in receipt of a substantial award from local authorities, the NHS Executive, Industry, Research Councils, the British Academy or other similar public bodies will not normally receive a grant from the Trust. Courses not eligible include electives, diplomas, placements, professional training and intercalated degrees. The Trust does not support students for full-time PhD studies beyond a 3rd year. Applicants must already be resident in the UK at the time of application.

Level of Study: Postgraduate

Type: Grant

Value: UK£400 and $£ 1,000$

Length of Study: Grants are awarded for 1 full academic year in the first instance

Frequency: Annual

Study Establishment: Any appropriate University

Country of Study: United Kingdom

No. of awards offered: Dependent on availability of funds

Application Procedure: Electronic applications are available in early January. The trust will consider either the first 300 complete applications or all applications received on or before deadline. Closing Date: When first 300 applications are received,

or March 30th

Funding: Trusts

No. of awards given last year: 183

No. of applicants last year: 295 
Additional Information: Please check at www.stapleytrust.org/wp/ about for more information.

\section{For further information contact:}

Email: admin@stapleytrust.org

Website: www.stapleytrust.org/wp/applications/

Email: admin@stapleytrust.org

\section{SIR ROBERT MENZIES MEMORIAL FOUNDATION}

210 Clarendon Street, East Melbourne, VIC, 3002, Australia

Tel: (61) 394195699

Fax: (61) 394177049

Email: menzies@vicnet.net.au

Website: www.menziesfoundation.org.au

Contact: Ms S K Mackenzie, General Manager

The Sir Robert Menzies Memorial Foundation is a non-profit, nonpolitical organization established in 1979 to perpetuate and honour the memory of Sir Robert Menzies by promoting excellence in medical and health research, education and post graduate scholarship by Australians.

\section{The Robert Gordon Menzies Scholarship to Harvard}

Subjects: All subjects.

Purpose: To encourage students who have gained admission to a Harvard graduate school.

Eligibility: Open to candidates who are Australian citizens who have graduated from an Australian university.

Level of Study: Postgraduate

Type: Scholarship

Value: US $\$ 60,000$

Frequency: Annual

Study Establishment: Harvard University

Country of Study: United States of America

No. of awards offered: 1

Application Procedure: A completed application form with original academic transcripts must be submitted.

Closing Date: February

Funding: Foundation

Contributor: The Harvard Club of Australia, the Menzies Foundation and the Australian National University

No. of awards given last year: 2

No. of applicants last year: 25

For further information contact:

Council and Boards Secretariat, 1.09 Chancelry Bld 10, The Australian National University, Canberra, ACT 0200, Australia Website: www.menziesfoundation.org.au/scholarships/scholarships. html\#harvard

Contact: Scholarship Administrator and Selection Committee Secretary

\section{Sir Robert Menzies Memorial Research Scholarships in the Allied Health Sciences}

Subjects: Occupational therapy, speech pathology, physiotherapy, psychology, nursing, optometry and physical education.

Purpose: To allow an outstanding applicant to carry out doctoral research work that is likely to improve the health of Australians. Eligibility: Open to Australian citizens of at least 5 years standing Applicants will generally have completed the first year of their PhD project.

Level of Study: Doctorate, Postgraduate

Type: Scholarship

Value: Australian $\$ 27,500$ free of income tax

Length of Study: 2 years

Frequency: Annual

Study Establishment: A tertiary institute with appropriate facilities Country of Study: Australia

No. of awards offered: 2
Application Procedure: Applicants must complete and submit an application form, academic transcripts and other documents. Further information is available on request.

Closing Date: June 30th

Funding: Private

Contributor: The Sir Robert Menzies Memorial Foundation

No. of awards given last year: 2

No. of applicants last year: 35

Additional Information: Please see the website for further details http://menziesfoundation.org.au/scholarships/allied-healthsciences.

\section{Sir Robert Menzies Memorial Scholarships in Engineering Subjects: Engineering}

Purpose: To enable Australian citizens to pursue postgraduate studies in the UK, generally leading to a higher degree.

Eligibility: Open to Australian citizens of 5 years of standing with at least an Upper Second Class (Honours) Degree in engineering at the time of application.

Level of Study: Postgraduate

Type: Scholarship

Value: Tuition fees, return airfare, examination and other compulsory fees, an allowance of UK£12,250 per year (if enrolled at a university outside London) and UK£14,250 per year (if enrolled at a London university)

Length of Study: 1-3 years

Frequency: Annual

Study Establishment: Universities in UK

Country of Study: United Kingdom

No. of awards offered: 1

Application Procedure: Applicants must complete and submit an application form along with academic transcripts and other documents.

Closing Date: July 31 st

Funding: Private

Contributor: The Sir Robert Menzies Memorial Trust in London, the Australian Department of Education, Employment and Workplace

Relations and the Menzies Foundation in Australia

No. of awards given last year: 1

No. of applicants last year: 12

Additional Information: Please see the website for further details www.menziesfoundation.org.au/scholarships.

\section{Sir Robert Menzies Memorial Scholarships in Law}

Subjects: Law.

Purpose: To enable Australian citizens to pursue postgraduate

studies in the UK, generally leading to a higher degree.

Eligibility: Open to Australian citizens of 5 years of standing with at least an Upper Second Class (Honours) Degree in law at the time of application

Level of Study: Postgraduate

Type: Scholarship

Value: Tuition fees, return airfare, examination and other compulsory fees, an allowance of UK£12,750 per year (if enrolled at a university outside London) and UK£14,750 per year (if enrolled at a London university)

Length of Study: $1-2$ years

Frequency: Annual

Study Establishment: Universities in UK

Country of Study: United Kingdom

No. of awards offered: 1

Application Procedure: Applicants must complete and submit an application form along with academic transcripts and other documents. Check website for details.

Closing Date: August 31st

Funding: Private

Contributor: The Sir Robert Menzies Memorial Trust in London, the Australian Department of Education, Employment and Workplace Relations, and the Menzies Foundation in Australia

No. of awards given last year: 1

No. of applicants last year: 35

Additional Information: Please see the website for further details http://menziesfoundation.org.au/scholarships/law. 


\section{THE SKIDMORE, OWINGS AND MERRILL FOUNDATION}

224 South Michigan Avenue, Suite 1000, Chicago, IL, 60604, United States of America

Tel: (1) 3124274202

Fax: (1) 3123604545

Email: somfoundation@som.com

Website: www.som.com

Contact: Ms Lisa Westerfield, Administrative Director

The mission of the Skidmore, Owings and Merrill Foundation is to identify and nurture emerging talent by sponsoring prestigious awards and travelling study grants to students of architecture, design, urban design and structural engineering. The SOM foundation identifies and supports individuals with the highest design aspirations, and enables them, through research and travel, to broaden their horizons and achieve excellence in their professional or academic careers. The foundation's goal is to instill in its fellows a heightened sense of responsibility as future leaders in the design disciplines by offering them an opportunity to deepen their understanding of the complexities of the built environment.

\section{SOM Prize and Travel Fellowship}

Subjects: Architecture, design and urban design.

Purpose: To help young architects and designers to broaden their education and take an enlightened view of society's need to improve the built and natural environments.

Eligibility: Open to candidates of any citizenship who are graduating from a university in the US. Fellowship winners must receive, prior to commencement of the fellowship, a Master's or Bachelor's degree in architecture, design or urban design. Students are eligible for nomination in the Spring of the academic year that they are due to graduate. Level of Study: Graduate, Postgraduate

Type: Fellowship

Value: The SOM Prize is a $\$ 50,000$ research and travel fellowship that enables one outstanding applicant the opportunity to travel in connection with carrying out in-depth research on a subject of their choosing. A second award, the $\$ 20,000$ SOM Travel Fellowship, offers an applicant the opportunity to expand their professional education beyond the classroom through the observation of buildings, design, culture and history that can only be achieved through travel Frequency: Annual

Study Establishment: Accredited schools, colleges or universities Country of Study: United States of America

No. of awards offered: 1 grand prize and 1 travel fellowship Application Procedure: Applicants must submit a portfolio with a proposed travel itinerary and a signed copyright release statement provided by the Foundation. Complete guidelines are available on request and on the website. Students must be nominated by the US school of attendance.

Closing Date: Please contact the organization for details

Funding: Private

No. of awards given last year: 3

Additional Information: Please see the website for further details www.somfoundation.som.com/award/travel-fellowship-design.

\section{Structural Engineering Travel Fellowship}

Subjects: The role of aesthetics, innovation, efficiency and economy in the structural design of buildings, bridges, and other structures. Purpose: To foster an appreciation of the aesthetic potential inherent in the structural design of buildings, bridges and other major works of architecture and engineering.

Eligibility: Open to candidates of any citizenship who are graduating from a university in the US with a Bachelor's, Master's or PhD degree in civil or architectural engineering and a specialization in structural engineering. Applicants must be nominated by the faculty and endorsed by the chair of the department from which they will receive the degree. Applicants must intend to enter the professional practice of structural engineering in the field of buildings or bridges.

Level of Study: Graduate, Doctorate, Postgraduate

Type: Fellowship

Value: US $\$ 20,000$

Frequency: Annual

Study Establishment: Accredited schools

Country of Study: United States of America
No. of awards offered: 1

Application Procedure: Complete guidelines are available on the website.

Closing Date: January 25th

Funding: Private

No. of awards given last year: 1

Additional Information: The fellowship hopes to encourage an awareness of the visual impact of structural engineering among engineering students and their schools. It also helps to strengthen the connection between aesthetics and efficiency, economy and innovation in structural design. Please see the website for further details www.somfoundation.som.com/award/structural-engineering.

\section{THE SMITH AND NEPHEW FOUNDATION}

\author{
15 Adam Street, London, WC2N 6LA, England \\ Tel: (44) 02074017646 \\ Fax: (44) 02079303353 \\ Email: barbara.foster@smith-nephew.com \\ Website: www.smith-nephew.com \\ Contact: Ms Barbara Foster, Foundation Coordinator
}

To contribute to the development of a robust evidence base which will inform the identification of effective interventions for the management and prevention of skin breakdown and tissue integrity. To concentrate our effort on developing research capacity in this field.

\section{Smith and Nephew Foundation Postdoctoral Nursing Research Fellowship}

Subjects: Nursing care of patients in the field of skin breakdown and tissue integrity.

Purpose: To influence and develop evidence-based nursing interventions in the field of skin breakdown and tissue integrity. Eligibility: Applications are invited from potential Fellows and the proposed host research team or unit. The host research team must be a university school, faculty or department of nursing and have a proven track record of research and development in the nursing care of patients with skin damage or tissue damage or vulnerability. Level of Study: Postdoctorate

Type: Fellowship

Value: Up to UK£120,000

Length of Study: Up to 3 years

Frequency: Annual

Country of Study: United Kingdom

No. of awards offered: 1

Application Procedure: Application forms must be completed.

Shortlisted candidates are interviewed in London.

Closing Date: May 1st

Funding: Foundation

Contributor: The Smith and Nephew Foundation

Additional Information: Research which will contribute to the evidence base for the nursing care of patients with skin or tissue damage and vulnerability, particularly in the following areas: Factors which influence the physiological response to tissue damage, the role of infection in delayed healing, factors which influence treatment decisions in skin/wound care, hidden cost of tissue damage. Applications which focus on research in other areas of skin, or tissue damage or vulnerability will also be considered. Please see the website for further details.

\section{SMITHSONIAN ASTROPHYSICS OBSERVATORY (SAO)}

60 Garden Street, Mail Stop 47, Cambridge, MA, 02138, United States of America

Email: predoc@cfa.harvard.edu Website: www.cfa.harvard.edu

Contact: Christine A Crowley, Fellowship Program Coordinator

SAO Predoctoral Fellowships

Subjects: Astronomy, astrophysics, atomic and molecular physics, planetary science, radio and geoastronomy, solar and stellar physics and theoretical astrophysics. 
Purpose: To allow students from other institutions throughout the world to undertake their thesis research at the SAO.

Eligibility: Applicants must have completed their preliminary course work and examinations and be ready to begin dissertation research at the time of the award.

Level of Study: Predoctorate

Type: Fellowship

Value: A stipend of $\$ 34,200$. Some funds may also be available for relocation, travel and other expenses

Length of Study: 6 months, with a possibility of renewal for up to a total of 3 years

Study Establishment: The Smithsonian Astrophysics Observatory Country of Study: United States of America

No. of awards offered: Varies

Application Procedure: Applicants must directly contact Smithsonian scientists in their area of interest to discuss possible research topics. Applicants must complete an application form available from the website.

Closing Date: Rolling admissions

No. of awards given last year: 6 awards

No. of applicants last year: 15

Additional Information: Please see the website for further details www.cfa.harvard.edu/opportunities/fellowships/predoc/.

\section{SMITHSONIAN ENVIRONMENTAL RESEARCH CENTER (SERC)}

Smithsonian Institution, PO Box 28, 647 Contees Wharf Road, Edgewater, MD, 21037-0028, United States of America Tel: (1) 4434822217

Email: gustafsond@si.edu

Website: www.serc.si.edu

Contact: Daniel E Gustafson, Jr, Professional Training \& Volunteer Coordinator

Smithsonian Environmental Research Center (SERC) is the world's leading research center for environmental studies of the coastal zone. For over 40 years, SERC has been involved in critical research, professional training for young scientists and environmental education.

\section{SERC Graduate Student Fellowship}

Subjects: Global climate change, marine invasion biology, forest and wetland ecology, trace element and nutrient cycling, solar UV radiation, water quality, food web dynamics, coastal and upland ecosystems, and plant-herbivore interactions.

Purpose: To financially support student research at Smithsonian facilities or research stations.

Eligibility: Students must be formally enrolled in a graduate program of study at a degree granting institution must have completed at least one full-time semester. Intended for students who have not yet been advanced to candidacy if in a doctoral program.

Level of Study: Graduate

Type: Fellowship

Value: US $\$ 7,000$

Length of Study: 10 weeks

Frequency: Annual

Application Procedure: Need to use Smithsonian online academic appointment system.

Closing Date: December 1st

Funding: Government

No. of awards given last year: 2

No. of applicants last year: 6

For further information contact:

Email: gustafsond@si.edu

Contact: Daniel Gustafson, Professional Training Coordinator

\section{SERC Postdoctoral Fellowships}

Subjects: Soil and water science, forestry, fishery, Marine biology, botany, zoology, and chemistry.

Purpose: To facilitate the Smithsonian's scholarly interactions with students and scholars at universities, museums and other research institutions around the world.
Eligibility: Open to scholars who held a PhD or equivalent degree for less than 7 years.

Level of Study: Postdoctorate, Predoctorate

Type: Fellowship

Value: US $\$ 48,000$ annually plus research, healthcare and relocation allowances

Length of Study: 12-24 months at SERC with the 2nd year of

funding contingent upon satisfactory progress and availability of funds Frequency: Annual

Application Procedure: Need to use Smithsonian online academic appoint system.

Closing Date: December 1st

Funding: Government

No. of awards given last year: 6

No. of applicants last year: 46

Additional Information: The Smithsonian Institution does not discriminate on grounds of race, creed, sex, age, marital status, condition of disability or national origin of any applicant. Fellowships are renewed after 1 st year if satisfactory progress is made.

\section{SERC Predoctoral Fellowships}

Subjects: Soil and water science, forestry, fishery, marine biology, botany, zoology, and chemistry.

Purpose: To financially support research at Smithsonian facilities or field stations.

Eligibility: Open to doctoral candidates who have completed preliminary course work and examinations and have been advanced to candidacy.

Level of Study: Postdoctorate

Type: Fellowship

Value: US $\$ 32,000$ per year plus allowances

Length of Study: 3-12 months

Frequency: Annual

Application Procedure: Applicants can download the application form from the website www.serc.si.edu/pro training/fellowships/ fellowships.aspx. The completed application form, current curriculum vitae and a formal research proposal must be sent to the Smithsonian Office of Fellowships

Closing Date: December 1st

Funding: Government

No. of awards given last year: 1

No. of applicants last year: 3

Additional Information: The Smithsonian Institution does not discriminate on grounds of race, creed, sex, age, marital status, condition of disability or national origin of any applicant

\section{SERC Senior Fellowships}

Subjects: Soil and water science, forestry, fishery, Marine biology, botany, zoology, and chemistry.

Purpose: To financially support research at Smithsonian facilities or field stations.

Eligibility: Offered to scholars who have held their degree or equivalent for less than 7 years. Senior fellowships are offered to scholars who held their degree or equivalent for 7 years or more. Level of Study: Research

Type: Fellowship

Value: US $\$ 48,000$ annually plus research, healthcare and relocation allowances

Length of Study: 12-24 months at SERC with the 2nd year of funding contingent upon satisfactory progress and availability of funds Frequency: Annual

Country of Study: United States of America

Application Procedure: Need to use Smithsonian online academic appointment system.

Closing Date: December 1st

Funding: Government

No. of awards given last year: 1

No. of applicants last year: 3

Additional Information: Senior fellowship applications may be submitted 2 years in advance.

For further information contact:

Office of Fellowships Smithsonian Institution PO Box 37012470 L'Enfant Plaza, SW, Washington DC, 20013 7012, United States of America 


\section{SMITHSONIAN INSTITUTION- NATIONAL AIR AND SPACE MUSEUM}

\author{
PO Box 37012, MRC 010, Washington, DC, 20013-7012, \\ United States of America \\ Tel: (1) 2026332648 \\ Fax: (1) 2027862447 \\ Email: NASM-Fellowships@si.edu \\ Website: www.airandspace.si.edu
}

Contact: Ms Collette Williams, Fellowships Programme Coordinator

\section{A Verville Fellowship}

Subjects: The history of aviation and space flights.

Purpose: To fund the analysis of major trends, developments and accomplishments in the history of aviation or space studies.

Eligibility: Open to all interested candidates who can demonstrate skills in research and writing. An advanced degree is not a requirement.

Level of Study: Postgraduate

Type: Fellowship

Value: An annual stipend of $\$ 55,000$ will be awarded for a 12-month fellowship, with limited additional funds for travel and miscellaneous expenses

Length of Study: 9-12 months, normally starts between June 1st and October 1st

Country of Study: United States of America

No. of awards offered: 1

Application Procedure: Candidates can apply using the online form. Closing Date: January 15th

Additional Information: Residence in the Washington, DC metropolitan area during the fellowship term is a requirement of this fellowship. Please see the website for further details http://airandspace.si.edu/research/fellowships/verville.cfm.

\section{The Aviation Space Writers Foundation Award}

Purpose: To support research on aerospace topics.

Type: Grant

Value: $\$ 5,000$

Frequency: Every 2 years

Application Procedure: Candidates should submit the online Aviation Space Writers Foundation Award Application form, including (1) a maximum two-page, single-spaced proposal stating the subject of their research and their research goals; (2) a one to two-page curriculum vitae; and (3) a one-page detailed budget explaining how the grant will be spent.

Closing Date: January 15th

Additional Information: Award winners are required to provide a summary report in the form of a memorandum to Ms Collette Williams that outlines how the grant was used to accomplish the goals of the project.

For further information contact:

Email: pisanod@si.edu

Website: http://airandspace.si.edu/getinvolved/fellow/writer_ grant.cfm

Contact: Dr Dominick A. Pisano

\section{Charles A Lindbergh Chair in Aerospace History}

Eligibility: Open to senior scholars with distinguished records of publication who are at work on, or anticipate being at work on, books in aerospace history.

Type: Fellowship

Value: Replacement of salary and benefits up to a maximum of $\$ 100,000$ a year. Research expenses and relocation are negotiable Length of Study: 12 months

Closing Date: January 15th

Additional Information: For more information, please contact David DeVorkin (DeVorkinD@si.edu) and see website.

\section{For further information contact:}

Email: PisanoD@si.edu

Website: http://airandspace.si.edu/getinvolved/fellow/lindfellow.cfm Contact: Dominick A. Pisano
The Guggenheim Fellowships

Subjects: Historical research related to aviation and space.

Purpose: To promote research into, and writing about, the history of aviation and space flight.

Eligibility: Postdoctoral fellowships are open to applicants who have received $\mathrm{a} P \mathrm{PhD}$ degree or equivalent within 7 years of the beginning of the fellowship period. Predoctoral fellowships are open to applicants who have completed preliminary coursework and examinations and are engaged in dissertation research. All applicants must be able to speak and write fluently in English.

Level of Study: Predoctorate, Postdoctorate

Type: Fellowship

Value: An annual stipend of $\$ 30,000$ for predoctoral candidates and $\$ 45,000$ for postdoctoral candidates will be awarded, with limited additional funds for travel and miscellaneous expenses

Length of Study: 3-12 months

Frequency: Annual

Study Establishment: A major portion of the research must be conducted at the Smithsonian Institution

Country of Study: United States of America

No. of awards offered: Varies

Application Procedure: Applicants must submit a summary description, research proposal, bibliography, estimated schedule, research budget, transcripts from all graduate institutions, English training with test scores and level of proficiency in reading, conversing and writing (if English is not the applicant's native language), a curriculum vitae and letters from 3 referees. 6 copies of the complete application must be submitted.

Closing Date: January 15th

Additional Information: Residence in the Washington, DC metropolitan area during the fellowship term is a requirement of the fellowship. Please see the website for further details http://airandspace.si.edu/research/fellowships/guggenheim.cfm.

\section{Postdoctoral Earth and Planetary Sciences Fellowship}

Subjects: Earth and planetary studies and global environment change.

Purpose: To support scientific research in earth and planetary studies. Scientists in the Center for Earth and Planetary Studies concentrate on geologic and geophysical research of the Earth and other terrestrial planets, using remote sensing data obtained from Earth-orbiting and interplanetary spacecraft.

Level of Study: Postdoctorate

Type: Fellowship

Value: Stipend

Application Procedure: Applicants must submit the application to NASM.

Additional Information: In years that the fellowship is offered, announcements will be made in the American Geophysical Union's professional publication EOS. Please see the website for further details http://airandspace.si.edu/research/fellowships/ceps.cfm.

\section{SMITHSONIAN NATIONAL AIR AND SPACE MUSEUM}

600 Independence Ave SW, Washington, DC 20560, United States of America Tel: (1) 2026332214

Website: https://airandspace.si.edu/ Contact: Miss Collette Williams

\section{A. Verville Fellowship}

Subjects: Aviation or space studies.

Purpose: To pursue programs of research and writing professional in tone and substance, but addressed to an audience with broad interests.

Value: $\$ 55,000$ per year

Length of Study: 9 months to 1 year

Application Procedure: All applications for the Verville Fellowships must be submitted electronically through the Smithsonian Online

Academic Appointment System (SOLAA).

Closing Date: November 1st

Additional Information: For any further queries, please contact NASM-Fellowships@si.edu or call (202) 633-2648. 
Charles A. Lindbergh Chair in Aerospace History

Eligibility: The Lindbergh Chair is open to established and recognized senior scholars with distinguished records of publication who are at work on, or anticipate being at work on, books in aerospace history

Value: $\$ 100,000$ per year

Length of Study: 1 year

Application Procedure: All applications for the Lindbergh Fellowships must be submitted electronically through the Smithsonian Online Academic Appointment System (SOLAA).

Closing Date: January 15th

Additional Information: For more information, please contact Layne Karafantis in the Aeronautics Department (karafantisl@si.edu) or Michael Neufeld in the Space History Department (neufeldm@si.edu).

\section{Engen Conservation}

Purpose: This fellowship is intended to contribute to the education of recent graduates by allowing them to continue research into traditional historic objects and delve into the complexities of working with modern composite materials.

Eligibility: Must have master's degree in conservation from a recognized programme and be able to conduct research independently.

Value: $\$ 37,000$ per year in addition to $\$ 3,000$ for medical insurance Length of Study: 1 year

Application Procedure: Applications are submitted through the Smithsonian Online Academic Appointment System (SOLAA) Closing Date: March 1st

Additional Information: For further queries, please contact CollumM@si.edu, Chief Conservator.

\section{Guggenheim Fellowships}

Subjects: Aviation and space history.

Purpose: To pursue programs of research and writing that support publication of works that are scholarly in tone and substance and intended for publication as articles in peer-reviewed journals or in book form from a reputable publisher (in the case of post postdoctoral applicants) or in a doctoral dissertation (in the case of pre-docs). Level of Study: Doctorate, Postdoctorate

Value: $\$ 30,000$ for predoctoral candidates and $\$ 45,000$ for postdoctoral candidates

Length of Study: 1 year

Application Procedure: All applications for the Guggenheim, Verville and Lindbergh Fellowships must be submitted electronically through the Smithsonian Online Academic Appointment System (SOLAA). Closing Date: January 15th

Additional Information: If you have any further questions, please contact NASM-Fellowships@si.edu or call (202) 633-2648.

\section{National Air and Space Museum}

Subjects: Aerospace studies.

Purpose: To support research on aerospace topics.

Value: $\$ 5,000$

Frequency: Every 2 years

Closing Date: January 15th

For further information contact:

Aeronautics Department, MRC 312, National Air and Space Museum, Smithsonian Institution, Washington, DC, PO Box 37012

Email: karafantisl@si.edu

Contact: Layne Karafantis

\section{THE SNOWDON TRUST}

Unit 18, Oakhurst Business Park, Southwater, Horsham, West Sussex, RH13 9RT, England Tel: (44) 1403732899

Email: info@snowdontrust.org.uk

Website: www.snowdontrust.org.uk Contact: Paul Alexander, CEO

The Snowdon Trust provides grants of up to UK£2,000 to physically disabled students for disability-related costs of further or higher education or training in the UK.
Snowdon Trust Grants

Subjects: All subjects.

Purpose: To support physically impaired students for further or higher education or training in the UK.

Eligibility: Physically impaired students studying in the UK.

Level of Study: Postgraduate, Unrestricted

Type: Award

Value: UK£250-2,000 (UK£2,500 in exceptional circumstances)

Frequency: Annual

Study Establishment: All recognized further, higher education or training centres

Country of Study: United Kingdom

No. of awards offered: Up to 100 per year, depending on funds

Application Procedure: Applicants must submit an application form and at least four specialized references. The application form is available online from January to September.

Closing Date: May 31st

Funding: Commercial, foundation, individuals, private, trusts

Contributor: Trusts and commercial sponsors

No. of awards given last year: 105

No. of applicants last year: 134

\section{SOCIAL SCIENCE RESEARCH COUNCIL (SSRC)}

One Pierrepont Plaza, 15th Floor, 300 Cadman Plaza West, Brooklyn, NY, 11201, United States of America

Tel: (1) 2123772700

Fax: (1) 2123772727

Email: info@ssrc.org

Website: www.ssrc.org

Contact: Director

Founded in 1923, the Social Science Research Council (SSRC) is an independent, non-governmental, non-profit international association devoted to the advancement of interdisciplinary research in the social sciences. The aim of the organization is to improve the quality of publicly available knowledge around the world.

\section{African Peacebuilding Network (APN) Residential Postdoctoral Fellowship Program}

Purpose: To support independent African research and its integration into regional and global policy communities.

Eligibility: Applicants must be African citizens currently residing in an African country. Researchers based in conflict-affected African countries or those recently emerging from conflict are especially encouraged to apply. Applicants must hold a faculty or research position at an African university and have completed their $\mathrm{PhD}$ within 7 years of the application deadline.

Level of Study: Research

Type: Fellowships

Value: A maximum of $\$ 20,000$

Frequency: Annual

No. of awards offered: Up to 4

Application Procedure: All applications must be uploaded through our online portal. For enquiries or technical questions pertaining to the portal, please contact APN staff (apn@ssrc.org). Unfortunately, due to the volume of applications we receive, no mailed materials will be accepted.

Closing Date: December

Additional Information: If you have questions, please contact APN program staff by telephone at (1) 2123772700 or by email at apn@ssrc.org.

For further information contact:

Tel: 2123772700

Email: apn@ssrc.org

Contact: APN program staff

\section{The Dissertation Proposal Development Fellowship} (DPDF)

Subjects: Humanities and social sciences.

Purpose: To help graduate students in the humanities and social sciences formulate doctoral dissertation proposals. 
Eligibility: Open to graduate students in the early phase of their research. Please check website www.ssrc.org/fellowships/dpdffellowship for more information.

Level of Study: Predoctorate

Type: Fellowship

Value: Fellows up to US $\$ 5,000$

Length of Study: 2 workshops and summer fieldwork funding

Frequency: Annual

No. of awards offered: 60

Application Procedure: Check website for further details - www. ssrc.org/programs/dpdf/.

Closing Date: October 15th

Funding: Foundation

Contributor: Andrew W. Mellon Foundation

No. of awards given last year: 60

No. of applicants last year: 450

Additional Information: Please see the website for further details www.ssrc.org/fellowships/dpdf-fellowship/.

\section{Drugs, Security and Democracy Fellowship}

Subjects: The competition is open to applicants conducting research in Latin America or the Caribbean who are fully embedded in and committed to the region, and whose research focus has a clear and central connection to the field of drugs and to formulating sound drug policy. Successful applicants will be those whose work and interests best match, and who demonstrate a long-term commitment to, these program goals.

Purpose: To support short-term research that contributes to the literature on drugs in Latin America and the Caribbean on topics and countries that are central to drug policy discussions in the region and beyond.

Eligibility: Applications are welcome from mid-career and senior researchers/scholars conducting research in Latin America and the Caribbean that addresses issues with a clear and central connection to the field of drugs and to formulating sound drug policy. Eligible applicants must: be committed to the Latin American and Caribbean region; hold a terminal degree in their field of study or clearly demonstrate equivalent research experience related to the field of drugs, with at least a bachelor's degree in any discipline; focus on one of the topics indicated in the section above; and; if proposing to conduct research in a nonnative language, provide evidence of sufficient language proficiency to carry out the project.

Level of Study: Postdoctorate, Research, Doctorate

Value: Research and living expenses as necessary for the project, as well as travel expenses to research site and a pre-field and a post-field workshop

Length of Study: 3-6 months

Frequency: Annual

No. of awards offered: Check website www.ssrc.org/fellowships/dsdfellowship

Application Procedure: Applicants are available on the SSRC website.

Closing Date: March 2nd

Funding: Private

Contributor: Open Society Foundations

Additional Information: Please see the website for further details www.ssrc.org/fellowships/dsd-fellowship/.

\section{ESRC/SSRC Collaborative Visiting Fellowships}

Subjects: Social sciences (including history).

Purpose: To encourage communication and cooperation between social scientists in Great Britain and the Americas.

Eligibility: Open to PhD scholars in the Americas, ESRC-supported centres, and holders of large grants awards or professorial fellowships in Britain.

Level of Study: Doctorate, Research

Type: Fellowship

Value: Up to US $\$ 9,500$

Length of Study: $1-3$ months

Frequency: Annual

No. of awards offered: Approx. 18

Application Procedure: Check website for further details. Closing Date: April 16th
For further information contact:

Email: international@esrc.ac.uk.

Website: www.ssrc.org/fellowships/esrc-ssrc-collaborative-visitingfellowships/

\section{Japan Society for the Promotion of Science (JSPS) Fellowship \\ Subjects: Social sciences and humanities.}

Purpose: To provide qualified researchers with the opportunity to conduct research at leading universities and other research institutions in Japan.

Eligibility: Applicants must be U.S. citizens or permanent residents at the time of application and submit proof of affiliation with an eligible host research institution in Japan as part of the application packet.

Permanent residents must provide a copy of a permanent resident card. Citizens of other countries are eligible for the short-term fellowship (1-12 months) if they have completed a Master's or PhD course at an institution of higher education in the US and, upon completing the course, have for at least three continuous years conducted high-level research at a university in the US. Applicants for long-term (12-24 months) fellowships must submit a copy of a PhD diploma dated no more than 6 years prior to applying. Check website for further details. Level of Study: Doctorate, Postdoctorate

Type: Fellowship

Value: Round-trip airfare, insurance coverage for accidents and illness, a monthly stipend and settling-in allowance. Applicants will also be eligible for additional funds annually for research expenses for stays of 1-2 years and a domestic travel allowance for stays of 3-12 months

Length of Study: 1 month to 2 years

Frequency: Annual

Study Establishment: An approved institution

Country of Study: Japan

No. of awards offered: Up to 20

Application Procedure: Applications are available on www.ssrc.org/ fellowships/jsps-fellowships.

Closing Date: December 1st

Funding: Government

Contributor: The Japan Society for the Promotion of Science

No. of awards given last year: $10-20$

No. of applicants last year: $25-40$

Additional Information: Fellows are selected by the Japan Society for the Promotion of Science based on nominations made by the SSRC Japan Advisory Board. Applicants will be notified of their nomination status by the following March. Successful applicants will be notified directly by JSPS in the summer.

For further information contact:

Tel: 212372700

Email: japan@ssrc.org

Website: www.ssrc.org/fellowships/jsps-fellowship/

\section{Mellon Mays Predoctoral Research Grants}

Subjects: Anthropology and archaeology, area/cultural/ethnic/gender studies, art history, classics, computer science, geography and population studies, earth/environmental/geological science and ecology, English, film, cinema and media studies (theoretical focus), musicology and ethnomusicology, foreign languages and literatures, history, linguistics, literature, mathematics, oceanographic/marine/ atmospheric/planetary science, performance studies (theoretical focus)philosophy and political theory, physics and astronomy, religion and theology, sociology, theater (non-performance focus).

Eligibility: Applicants must be a Mellon fellow enrolled in a doctoral program. Applicants must have been selected as Mellon Mays Fellows as undergraduates. Fellows may apply for one grant per year and must be enrolled in a doctoral program in one of the fields listed in the website or have filed a petition for inclusion of another field.

Value: Total of $\$ 5,000$ in GSE and PRD funds; DCG grant money is not applied towards this total

Application Procedure: Applicants should use the online application portal to apply. For detailed information, please visit: www.ssrc.org/ fellowships/mellon-mays-predoctoral-research-grants/.

Closing Date: November 1st

Additional Information: If accepted, grants take 5-6 weeks to process. 


\section{SSRC Abe Fellowship Program}

Subjects: Social sciences and related fields relevant to any one or combination of (i) traditional and non-traditional approaches to security and diplomacy; (ii) global and regional economic issues; (iii) the role of civil society.

Purpose: To encourage international multidisciplinary research on topics of pressing global concern and to foster the development of a new generation of researchers who are interested in policy-relevant topics of long-range importance and who are willing to become key members of a bilateral and global research network built around such topics.

Eligibility: Open to citizens of Japan and the US and to other nationals who can demonstrate serious and long-term affiliations with research communities in Japan or the US. Applicants must hold a PhD or have attained an equivalent level of professional experience. Applications from researchers in non-academic professions are welcome.

Level of Study: Postdoctorate

Type: Fellowship

Value: Research and travel expenses as necessary for the completion of the research project in addition to limited salary replacement Length of Study: Up to 1 year

Frequency: Annual

Study Establishment: An appropriate institution

Country of Study: United States of America

No. of awards offered: Approx. 14

Application Procedure: Applicants must submit an online application along with a writing sample, letter of reference and an optional language evaluation form.

Closing Date: September 1st

Funding: Foundation

Contributor: The Japan Foundation Center for Global Partnership

No. of awards given last year: 14

No. of applicants last year: $60-100$

Additional Information: In addition to working on their research projects, Fellows will attend annual conferences and other events sponsored by the program, which will promote the development of an international network of scholars concerned with research on contemporary policy issues. Funds are provided by the Japan Foundation Center for Global Partnership.

For further information contact:

Email: abe@ssrc.org

Website: www.ssrc.org/fellowships/abe-fellowship/

\section{SSRC International Dissertation Research \\ Fellowship}

Subjects: Non-U.S. cultures and societies grounded in empirical and site-specific research (involving fieldwork, research in archival or manuscript collections, or quantitative data collection).

Purpose: To support distinguished graduate students in the humanities and social sciences conducting dissertation research outside the US.

Eligibility: Open to full-time graduate students in the humanities and social sciences regardless of citizenship enroled in doctoral programs in the US. Applicants must complete all PhD requirements except onsite research by the time the fellowship begins.

Level of Study: Doctorate

Type: Fellowship

Value: Approx. US $\$ 20,000$

Length of Study: 9-12 months

Frequency: Annual

No. of awards offered: Approx. 75

Application Procedure: Applications are available on SSRC website. Closing Date: November 3rd

Funding: Private

Contributor: The Andrew W Mellon Foundation

Additional Information: Applicants must contact the programme for further information by emailing.

For further information contact:

Email: idrf@ssrc.org

Website: www.ssrc.org/fellowships/idrf-fellowship/
SOCIAL SCIENCES AND HUMANITIES RESEARCH COUNCIL (SSHRC)

Research Training Portfolio, Social Sciences and Humanities Research Council, 350 Albert Street, PO Box 1610, Ottawa, ON K1P 6G4, Canada

Tel: 6139437777

Fax: 6139431329

Email: fellowships@sshrc-crsh.gc.ca

The Social Sciences and Humanities Research Council of Canada (SSHRC) is the federal agency responsible for promoting and supporting research and research training in the social sciences and humanities in Canada. SSHRC supports research on the economic, political, social and cultural dimensions of the human experience.

\section{Aid to Research and Transfer Journals}

Subjects: Social sciences and humanities.

Purpose: To assist in the effective dissemination of original research findings and in the transfer of knowledge to practitioners.

Eligibility: Open to candidates who are either Canadian citizens or permanent residents of Canada at the time of application and are established researchers in the social sciences or in the humanities.

They must also be a member of the sponsoring institution or organization and not be under SSHRC sanction for financial or research misconduct. Check SSHRC website for further details.

Level of Study: Research

Type: Grant

Value: Check SSHRC website for further details

Frequency: Every 3 years

Country of Study: Canada

Application Procedure: Applicants must make the case for the funding requested. For full details on application visit the website.

Closing Date: June 30th

Funding: Government

\section{Aid to Scholarly Journals}

Subjects: Social sciences and humanities.

Purpose: To promote the sharing of research results by assisting the publication of individual works that make an important contribution to the advancement of knowledge.

Eligibility: Applicants must consult the Canadian Federation for the Humanities and Social Sciences website for eligibility requirements.

Level of Study: Postdoctorate, Research

Type: Grant

Value: Up to $\$ 30,000$ per year

Length of Study: 3 years

Frequency: Annual

Application Procedure: Applicants must refer to the website or email the Humanities and Social Sciences Federation of Canada.

Closing Date: June 2nd

Funding: Government

Additional Information: The program is administered on behalf of SSHRC by the Humanities and Social Sciences Federation of Canada.

\section{For further information contact:}

The Humanities and Social Sciences Federation of Canada, 151 Slater Street, Ottawa, ON, K1P 5H3, Canada

Tel: (1) 6132386112 ext. 350

Email: secaspp@fedcan.ca

\section{Aid to Small Universities}

Subjects: Arts, humanities and social sciences.

Purpose: To enable the focused development of social sciences and humanities research capacity in small universities.

Eligibility: Open to institutions that have active degree-granting status for social sciences and humanities disciplines at the undergraduate level or beyond, and are institutional members of the Association of Universities and Colleges of Canada (AUCC), or institutional members of the AUCC and affiliated with an institution itself too large to be eligible for the ASU Program. Institutions applying must also have fewer than 250 full-time faculty in SSHRC fields and be independent of the federal government for the purpose of faculty employment status. 
Level of Study: Research

Type: Grant

Value: Up to a maximum of Canadian $\$ 30,000$

Length of Study: 3 years

Frequency: Every 3 years

Country of Study: Canada

Application Procedure: Applicants must contact the organization or visit the SSHRC website.

Closing Date: December 1st

Funding: Government

Additional Information: Please see the website for further details

www.mta.ca/research_activities/development/small_com_index.html.

\section{Aileen D Ross Fellowship}

Subjects: Sociology.

Purpose: To support an outstanding SSHRC Doctoral Award or Postdoctoral Fellowship holder who is conducting research in

sociology, especially on poverty.

Eligibility: Open to Canadian citizens or permanent residents living in Canada at the time of application who are not under SSHRC sanction resulting from financial or research misconduct, or already in receipt of SSHRC, NSERC or CIHR funding to undertake or complete a previous doctoral or combined MA or PhD degree. At the time of taking up the award, applicants must have completed either a Master's degree or at least 1 year of doctoral study, and be pursuing either full-time studies leading to a $\mathrm{PhD}$ or equivalent, with a research specialization in sociology and with the intention of pursuing an academic career Candidates wishing to study at a foreign university may only do so if at least one of their previous degrees was earned in Canada.

Level of Study: Doctorate, Postdoctorate

Type: Fellowship

Value: Canadian $\$ 10,000$ plus the value of the fellowship

Length of Study: 1 year

Country of Study: Canada

No. of awards offered: 1

Application Procedure: Applicants must indicate their interest on their doctoral or postdoctoral application form.

Closing Date: Postdoctoral applications are due October 6th. For applicants registered at a Canadian university: University sets the deadline. For all others: November 5th

Funding: Government, trusts

Additional Information: Preference will be given to postdoctoral applicants. Please see the website for further details www.sshrc-crsh. gc.ca/results-resultats/prizes-prix/fellowships-bourses-eng.aspx.

\section{Bora Laskin National Fellowship in Human Rights \\ Research}

Subjects: Human rights, as relevant to Canada.

Purpose: To support research, preferably of a multidisciplinary or interdisciplinary nature, and to develop Canadian expertise in the field of human rights, with an emphasis on themes and issues relevant to the Canadian human rights scene.

Eligibility: Open to Canadian citizens or permanent residents of Canada. Preference will be given to applicants with at least 5 years of proven research experience in their field, as this fellowship is not intended for scholars just beginning their research careers. The successful candidate must not be under SSHRC sanction for financial or research misconduct.

Level of Study: Postdoctorate, Research

Type: Fellowship

Value: Canadian $\$ 40,500$ plus a research and travel allowance of Canadian $\$ 10,000$

Length of Study: 1 year, non-renewable

Frequency: Annual

No. of awards offered: 1

Application Procedure: Applicants must complete an application form, available from the SSHRC website.

Closing Date: October 1st

Funding: Government

\section{Canadian Initiative on Social Statistics: Data Training \\ Schools}

Subjects: Social sciences.

Purpose: To promote research and training in the application of Canadian social statistics.
Eligibility: Eligible applicants include research groups, departments and centres that are operating in a Canadian university. Eligible participants include students and researchers at a variety of levels. Level of Study: Graduate, Doctorate, Postdoctorate, Predoctorate,

Research

Type: Grant

Value: Up to Canadian $\$ 50,000$ per year

Length of Study: 3 years

Frequency: Annual

Application Procedure: Applicants must visit the SSHRC website for application forms and instructions.

Closing Date: December 7th

\section{Joseph-Armand Bombardier Canada Graduate Scholarship Program (CGS): Master's Scholarship}

Subjects: Social sciences and humanities.

Purpose: To support graduate students working towards a Master's degree at a Canadian university.

Eligibility: Open to citizens or permanent residents of Canada who are applying for, or registered in a Master's programme in the social sciences or humanities at a Canadian university.

Level of Study: Predoctorate, Graduate

Type: Scholarship

Value: Canadian $\$ 17,500$

Length of Study: 1 year

Frequency: Annual

Country of Study: Canada

No. of awards offered: Several hundred

Application Procedure: Applicants must visit the SSHRC website for further information.

Closing Date: December 13th (direct application) and February 4th (university application)

Funding: Government

No. of awards given last year: Hundreds

No. of applicants last year: Thousands

\section{Jules and Gabrielle Léger Fellowship}

Subjects: The Crown and Governor General in a parliamentary democracy.

Purpose: To promote better understanding of the diverse contributions of the crown and its representatives to all aspects of Canadian life.

Eligibility: Open to Canadian citizens or permanent residents of Canada. Applicants must be affiliated with a post secondary institution not be under SSHRC sanction for financial or research misconduct. Preference will be given to applicants with at least 5 years of proven research experience in their field.

Level of Study: Postdoctorate, Research

Type: Fellowship

Value: Canadian $\$ 40,000$, plus Canadian $\$ 10,000$ for research and travel costs

Length of Study: 1 year, non-renewable

Frequency: Every 2 years

Study Establishment: A recognized Canadian post secondary institution

Country of Study: Any country

No. of awards offered: 1

Application Procedure: Applicants must visit the SSHRC website for full application details.

Closing Date: October 1st

Funding: Government

\section{Knowledge Impact in Society}

Subjects: Social sciences and humanities.

Purpose: To support university-based knowledge mobilization initiatives that will enable non-university stockholders to benefit from existing social sciences and humanities research.

Eligibility: The programme offers institutional grants, which are available only to universities eligible for SSHRC Institutional Grants. Applicants must check SSHRC website for full details.

Level of Study: Research

Type: Grant

Value: Up to Canadian $\$ 100,000$ per year

Length of Study: Up to 3 years

Frequency: Annual 
Application Procedure: Applicants must visit the website for application forms and instructions.

Closing Date: Visit website

Funding: Government

Additional Information: For further details, please refer the website: www.sshrc-crsh.gc.ca/funding-financement/programs-programmes/ impact awards-prix impacts-eng.aspx.

\section{Northern Research Development Program}

Subjects: Social sciences and humanities.

Purpose: To support research in and about the Canadian North, with emphasis on involving local stakeholders.

Eligibility: Open to individual researchers or groups of researchers affiliated with Canadian postsecondary institutions or from other organizations whose proposed activities include significant involvement of researchers affiliated with Canadian postsecondary institutions. For further details check the SSHRC website.

Level of Study: Research

Type: Grant

Value: Up to Canadian $\$ 40,000$

Length of Study: Up to 2 years

Frequency: Annual

Country of Study: Canada

Application Procedure: Applicants must visit the SSHRC website for application information, forms and instructions.

Closing Date: November 8th

Funding: Government

\section{Queen's Fellowships}

Subjects: Canadian studies.

Purpose: To assist an outstanding candidate who intends to enter a doctoral program in the relevant field.

Eligibility: Open to Canadian citizens and permanent residents who, by the time of taking up the fellowship, will have completed 1 year of graduate study or all the requirements for the master's degree beyond the bachelor's (honours) degree or its equivalent, and will be registered in a program of studies leading to $\mathrm{ahD}$ or its equivalent. This award is offered to one or two outstanding and successful doctoral fellowship candidates.

Level of Study: Doctorate

Type: Fellowship

Value: Tuition fees and travel to the main place of tenure and travel for research purposes

Length of Study: 1 year, non-renewable

Frequency: Annual

Study Establishment: A recognized university

Country of Study: Canada

No. of awards offered: $1-2$

Application Procedure: Applicants cannot apply for this award, but are automatically eligible if they intend to study Canadian studies at a Canadian university. The Queen's Fellowship is not a program, but a special award given to a doctoral fellow.

Closing Date: Before March 1st

Funding: Government

Additional Information: For further details, please refer to the website: www.queensu.ca/calendars/sgsr/Fellowships.html.

\section{Sport Participation Research Initiative: Research Grants}

Subjects: Social sciences and humanities.

Purpose: To support policy-relevant research about participation in sport in Canada.

Eligibility: Open to individuals and research teams must be affiliated with Canadian postsecondary institutions who are working in one or more of the target areas of interest. For further information check the SSHRC website.

Level of Study: Research

Type: Grant

Value: Up to Canadian $\$ 100,000$ per year

Length of Study: Up to 3 years

Frequency: Annual

Country of Study: Canada

Application Procedure: Applicants must visit the SSHRC website for application forms and instructions.

Closing Date: October 15th (Research Grants); October 6th

(Postdoctoral Fellowship Supplements); check website for Doctoral Award Supplement
Funding: Government

Additional Information: Please see the website for further details www.sshrc-crsh.gc.ca/funding-financement/programs-programmes/ sport_can-eng.aspx.

\section{SSHRC Doctoral Awards}

\section{Subjects: Social sciences and humanities.}

Purpose: To develop research skills and to assist in the training of highly qualified academic personnel by supporting students who demonstrate a high standard of scholarly achievement.

Eligibility: Open to Canadian citizens or permanent residents living in Canada at the time of application, who are not under SSHRC sanction resulting from financial or research misconduct, or already in receipt of SSHRC, NSERC or CIHR funding to undertake or complete a previous doctoral or combined $\mathrm{MA} / \mathrm{PhD}$ degree. At the time of taking up the award applicants must have completed either a Master's degree or at least 1 year of doctoral study, and be pursuing either fulltime studies leading to a $\mathrm{PhD}$ or equivalent. Candidates wishing to study at a foreign university may only do so if at least one of their previous degrees was earned in Canada.

Level of Study: Doctorate

Type: Fellowship/Scholarship

Value: SSHRC doctoral fellowships: Canadian $\$ 20,000$ per year, up to and including the 4th year of doctoral study (tenable in Canada and abroad); CGS doctoral scholarship: Canadian $\$ 35,000$ per year for 3 years (tenable only at Canadian universities)

Length of Study: $1-4$ years

Frequency: Annual

Study Establishment: Any recognized universities

Country of Study: SSHRC doctoral fellowships: tenable in Canada or abroad; CGS doctoral scholarships: tenable in Canada only

No. of awards offered: Varies

Application Procedure: Applicants must complete an application form along with a detailed description. Forms are available from the SSHRC website.

Closing Date: Direct applications: November 5th, University applications: January 8th

Funding: Government

Additional Information: Please see the website for further details www.sshrc-crsh.gc.ca/funding-financement/index-eng.aspx\#resultsresultats.

\section{SSHRC Impact Awards}

Subjects: Social sciences and humanities.

Eligibility: Open to Canadian citizen or permanent resident of

Canada and be affiliated with an institution eligible to administer SSHRC funds.

Type: Award

Value: $\$ 50,000$ or $\$ 100,000$ (Gold Medal $(\$ 100,000)$; Talent Award $(\$ 50,000)$; Insight Award $(\$ 50,000)$; Connection Award $(\$ 50,000)$;

Partnership Award $(\$ 50,000)$

Country of Study: Canada

Closing Date: April 5th

Additional Information: Please mail nomination packages to:

Research Training Portfolio Social Sciences and Humanities Research Council, 350 Albert Street, PO Box 1610, Ottawa, ON K1P 6G4.

\section{SSHRC Institutional Grants}

Subjects: Social sciences and humanities.

Purpose: To help universities develop and maintain a solid base of research and research-related activities.

Eligibility: Open to Canadian postsecondary institutions only.

Level of Study: Postgraduate

Type: Research grant

Value: Minimum Canadian $\$ 5,000$ per year

Length of Study: 3 years

Frequency: Annual

Country of Study: Canada

No. of awards offered: Varies

Application Procedure: Applicants must complete an application form available from the SSHRC website.

Closing Date: December 1st

Funding: Government 


\section{SSHRC Postdoctoral Fellowships}

Subjects: Social sciences and humanities.

Purpose: To support the most promising new scholars and to assist them in establishing a research base at an important time in their research career.

Eligibility: Open to candidates who are Canadian citizens or permanent residents living in Canada at the time of application. They must also be able to demonstrate skill in research, not be under SSHRC sanction resulting from financial or research misconduct and have earned their doctorate from a recognized university no more than 3 years prior to the competition deadline or have completed their degree within 6 years prior to the competition deadline, but have had their career interrupted or delayed for the purpose of child-rearing. Candidates must also have finalized arrangements for affiliation with a recognized university or research institution and have applied not more than twice before for a SSHRC postdoctoral fellowship. At the time of taking up the award, applicants must have completed all requirements for the doctoral degree, must intend to engage in fulltime postdoctoral research for the period of the award and not hold or have held a tenure or tenure-track position.

Level of Study: Postdoctorate

Type: Fellowship

Value: Up to Canadian $\$ 40,500$ per year

Length of Study: 12-24 Months

Frequency: Annual

Study Establishment: For applicants who earned their doctorate at a Canadian University, there is no restriction on the location of the tenure

Country of Study: Any country, under certain conditions

No. of awards offered: Approx. 100

Application Procedure: Applicants must complete an application form available in the SSHRC website.

Closing Date: September 23rd

Funding: Government

No. of awards given last year: 140

No. of applicants last year: 558

Additional Information: Applicants wishing to hold their award at a foreign university may do so only if their PhD was earned at a Canadian university. Please see the website for further details www. sshrc-crsh.gc.ca/funding-financement/index-eng.aspx\#resultsresultats.

\section{SSHRC Strategic Research Grants}

Subjects: Social sciences and humanities.

Purpose: To support targeted research and research-related activities in areas of national importance. SSHRC offers many separate programs to support strategic research. See the website for current offerings.

Eligibility: Varies as per requirements.

Level of Study: Research, Doctorate, Postgraduate

Type: Grant

Value: Up to $\$ 12,000$ per year for master's student; up to $\$ 15,000$ per year for doctoral students; up to $\$ 31,500$ per year postdoctoral student Length of Study: $1-5$ years

Frequency: Annual

Country of Study: Canada

Application Procedure: Applicants must visit the website for full application details.

Closing Date: Varies according to program

Funding: Foundation, government, trusts

Additional Information: Please see the website for further details www.sshrc-crsh.gc.ca/funding-financement/using-utiliser/grant_ regulations-reglement_subventions/strat_grants-subventions _ strat-eng.aspx.

\section{Thérèse F Casgrain Fellowship}

Subjects: Women and social change in Canada.

Purpose: To carry out research in the field of social justice, particularly in the defence of individual rights and the promotion of the economic and social interests of Canadian women.

Eligibility: Open to Canadian citizens or permanent residents. At the time of taking up the fellowship, the successful candidate must have obtained a doctorate or an equivalent advanced professional degree, as well as have proven research experience and not be under SSHRC sanction for financial or research misconduct.
Level of Study: Postdoctorate

Type: Fellowship

Value: Canadian $\$ 40,000$, paid in three installments, of which up to Canadian $\$ 10,000$ may be used for travel and research expenses

Length of Study: 1 year, non-renewable

Frequency: Every 2 years

Country of Study: Canada

No. of awards offered: 1

Application Procedure: Applicants must complete an application form, available from the website. Application forms and instructions are available on the SSHRC website.

Closing Date: October 1st

Funding: Private

Contributor: The Thérèse $\mathrm{F}$ Casgrain Foundation

No. of awards given last year: 1

No. of applicants last year: 21

Additional Information: The fellowship was created by the Thérèse F Casgrain Foundation and is administered by the Social Sciences and Humanities Research Council. Affiliation with a university or an appropriate research institute or similar organization is desirable, but is not a condition of the award. Recipients must submit a final report to the Foundation outlining conclusions of the research, accompanied by a complete financial statement for all expenses.

\section{SOCIAL WORKERS EDUCATIONAL TRUST}

British Association of Social Workers, 16 Kent Street, Birmingham, West Midlands, B5 6RD, England

Tel: (44) 1216223911

Fax: (44) 1216224860

Email: swet@basw.co.uk

Website: www.socialworkerseducationaltrust.org

Contact: Ms Gill Aslett, Honorary Secretary

The Social Workers Educational Trust offers grants and scholarships to experienced social workers for post qualifying training or research, with the overall aim of improving social work practice in the UK.

\section{Anne Cummins Scholarship}

Subjects: Health-related social work.

Purpose: To support study or research on health-related social work practice.

Eligibility: Open to qualified social workers who have completed

2 years of work practice post qualification, resident in the UK.

Level of Study: Postgraduate, Professional development

Type: Scholarship

Value: UK£1,000-1,500

Frequency: Annual

Country of Study: United Kingdom

No. of awards offered: 1

Application Procedure: Applicants must complete an application form. Details and forms are available on written request from the

Trust, at the Birmingham address.

Closing Date: May (check with website)

Funding: Private

No. of awards given last year: 1

\section{SOCIETY FOR PROMOTION OF ROMAN STUDIES}

Roman Society, Room 252, South Block, Senate House, Malet Street, London, WC1E 7HU, England

Tel: (44) 02078628727

Fax: (44) 02078628728

Email: office@romansociety.org

Website: www.romansociety.org

Contact: Dr Fiona Haarer, Secretary of Society

The Society for the Promotion of Roman Studies aims to promote the study of history, architecture, archaeology, language, literature and the art of Italy and the Roman Empire, including Roman Britain, from the earliest times to about $700 \mathrm{AD}$. 


\section{Audrey Barrie Brown and Donald Atkinson Funds}

Subjects: The art history and archaeology of the Roman empire and Roman Britain.

Purpose: To assist in the undertaking, completion or publication of work that relates to general. The art and archaeology of the Roman empire and Roman Britain.

Eligibility: Open to applicants of graduate, postgraduate or postdoctoral status or the equivalent, usually of UK nationality.

Level of Study: Graduate, Postdoctorate, Postgraduate, Research Type: Grant

Value: Varies, but up to UK£5,000

Frequency: Annual

No. of awards offered: 20

Application Procedure: Applicants must ensure that two references are sent directly to the Society. Completion of an application form is essential. See the guidelines and download an application form from www.romansociety.org/grants-prizes/audrey-barrie-brown-memorialfund-donald-atkinson-fund.html.

Closing Date: January 31 st

Funding: Private

No. of awards given last year: 11

No. of applicants last year: 19

\section{Hugh Last Fund and General Fund}

Subjects: History, language and literature of the Roman empire. Purpose: To assist in the undertaking, completion, or publication of works relating to the general scholarly purposes of the Roman Society, excluding expenses in connection with archaeological projects. The Hugh Last Fund also excludes travelling, hotel, conference, or other living expenses of scholars.

Level of Study: Graduate, Postdoctorate, Postgraduate, Research Value: Varies $£ 100-1,000$

Frequency: Annual

No. of awards offered: $10-15$

Application Procedure: Applications should be made using the application form - the completed application should not exceed two sides of A4. Applicants should give a concise and clear outline of the project, including publication plans if relevant, and itemise the costs requested. They must declare any other applications being made for the same project. Completed applications should be sent to the Secretary by email: office@romansociety.org. Download the application form from www.romansociety.org/grants-prizes/hugh-last-fund. $\mathrm{html}$. See the guidelines and download an application form from: www. romansociety.org/grants-prizes/hugh-last-fund-general-fund.html.

Closing Date: January 31st

Additional Information: Individuals may not make more than one application in any year.

\section{SOCIETY FOR THE ARTS IN RELIGIOUS AND THEOLOGICAL STUDIES (SARTS)}

United Theological Seminary of the Twin Cities, 3000 5th Street NW, New Brighton, MN, 55112, United States of America

Tel: (1) 6512556117,6512556190 Fax: (1) 6516334315

Email: wyates@unitedseminary-mn.org Website: www.artsmag.org

Contact: Wilson Yates

The Society for the Arts in Religious and Theological Studies (SARTS) was organized to provide a forum for scholars and artists interested in the intersections between theology, religion and the arts to share thoughts, challenge ideas, strategize approaches in the classroom and to advance the discipline in theological and religious studies.

\section{Luce Fellowships}

Subjects: Intersection of theology and art.

Purpose: To enhance and expand the conversation on theology and art.

Eligibility: Open to candidates teaching theology as a faculty member at an accredited postsecondary educational institution or graduate students.

Level of Study: Research, Graduate

Type: Fellowships

Value: Awards are up to $\$ 3,000$ each
Length of Study: 1 year

Frequency: Annual

No. of awards offered: 2

Application Procedure: Applicants must submit an information

sheet, curriculum vitae, a project abstract, a formal proposal, a budget and 2 letters of recommendation.

Closing Date: May 15th

For further information contact:

University of St Thomas, Mail JRC 1532115 Summit Avenue, St Paul, MN, 55105, United States of America

Email: office@societyarts.org

Website: www.societyarts.org/fellowships/guidelines

Contact: Kayla Larson

\section{THE SOCIETY FOR THE PROMOTION OF HELLENIC STUDIES}

\author{
Senate House, Malet Street, London, WC1E 7HU, England \\ Tel: (44) 02078628730 \\ Fax: (44) 02078628731 \\ Email: office@hellenicsociety.org.uk \\ Website: www-hellenicsociety.org.uk \\ Contact: Secretary
}

The Society for the Promotion of Hellenic Studies, generally known as the Hellenic Society, was founded in 1879 to advance the study of Greek language, literature, history, art and archaeology in the ancient, Byzantine and modern periods.

\section{The Dover Fund}

Subjects: Greek language and papyri.

Purpose: To further the study of the history of the Greek language in any period from the Bronze Age to the 15th century AD, and to further the edition and exegesis of Greek texts from any period within those same limits.

Eligibility: Open to currently registered research students and lecturers, teaching Fellows, research Fellows, postdoctoral Fellows and research assistants who are within the first 5 years of their appointment. Level of Study: Doctorate, Postdoctorate, Postgraduate

Type: Grant

Value: Grants will be made for such purposes as: books, photography, visits to libraries, museums and sites. The sums awarded will vary according to the needs of the applicant, but most grants will be in the range $£ 50-400$

Frequency: Annual

Study Establishment: The Society for the Promotion of Hellenic

Studies

Country of Study: United Kingdom

No. of awards offered: Varies

Application Procedure: Applicants must complete an application form, available from the Society. Applications should be marked for the attention of the Dover Fund and sent to the main address.

Closing Date: May 1st

Funding: Private

Contributor: Membership subscriptions

No. of awards given last year: 3

No. of applicants last year: 8

Additional Information: Please see the website for further details www.hellenicsociety.org.uk/grants/.

\section{THE SOCIETY FOR THE PSYCHOLOGICAL STUDY OF SOCIAL ISSUES (SPSSI)}

SPSSI Central Office, 208 I Street NE, Washington, DC, 20002-4340, United States of America

Tel: (1) 2026756956

Fax: (1) 2026756902

Email: spssi@spssi.org

Website: www.spssi.org

Contact: Alex Ingrams, Administrative Assistant 
The Society for the Psychological Study of Social Issues (SPSSI) is an interdisciplinary, international organization of over 3,000 social scientists who share an interest in research on the psychological aspects of important social issues. The Society's goals are to increase the understanding of social issues through research and its dissemination and to support policy efforts consistent with such research.

\section{Clara Mayo Grants}

Subjects: Aspects of sexism, racism and prejudice.

Purpose: To support masters' theses or pre-dissertation research on aspects of sexism, racism, or prejudice.

Eligibility: Open to individuals who are SPSSI members and who have matriculated in graduate programs in psychology, applied social science, and related disciplines. A student who is applying for a Grants-In-Aid may not apply for the Clara Mayo award in the same award year. Applicants may submit only one Mayo application per calendar year. Proposals that include a college or university agreement to match the amount requested will be favored, but proposals without matching funds will also be considered.

Level of Study: Postgraduate, Graduate

Type: Research grant

Value: Up to US $\$ 1,000$ (Proposals that include a college or university agreement to match the amount requested will be favored, but proposals without matching funds will also be considered.)

Country of Study: Any country

No. of awards offered: Up to 6

Application Procedure: The Application should include: (1) A cover sheet stating title of thesis proposal, name of investigator, address, phone, and if possible, fax and email; (2) an abstract of no more than 100 words summarizing the proposed research; (3) project purposes, theoretical rationale, research methodology, and analytic procedures to be employed; (4) relevance of research to SPSSI goals and funding criteria; (5) status of human subjects review process (which must be satisfactorily completed before grant funds can be forwarded);

(6) clear statement of type of degree program applicant is enroled in (e.g., terminal master's program); (7) faculty advisor's recommendation, including certification that the proposal is for a master's thesis or for pre-dissertation research; (8) specific amount requested, including a budget; (9) if available, an institutional letter of agreement to match the funds requested. Recommended length for points (1) through (4) of the application is 5-7 double-spaced, 12-point font, typed pages. Closing Date: May 2nd and October 15th

Funding: Private

No. of awards given last year: 5

No. of applicants last year: 10

Additional Information: Incomplete applications will be returned. Late applications may be held until the next deadline. Please see the website for further details www.spssi.org/index.cfm?fuseaction = page viewpage\&pageid $=727$.

\section{Louise Kidder Early Career Award}

Subjects: Social and community psychology.

Purpose: To recognize social issues researchers who have made substantial contributions to the field early in their careers.

Eligibility: Nominees should be social issues investigators who have made substantial contributions to social issues research within 5 years of receiving a graduate degree and who have demonstrated the potential to continue such contributions. Nominees need not be current SPSSI members.

Level of Study: Postdoctorate, Professional development

Type: Award

Value: US $\$ 500$ plus plaque

Frequency: Annual

Country of Study: Any country

No. of awards offered: 1

Application Procedure: The online application form should be completed and sent as an email attachment. For further details visit the website. Application should include a cover letter outlining the nominee's accomplishments to date and anticipated future contributions, the nominee's curriculum vitae and three letters of support.

Closing Date: June 20th

Funding: Private

No. of awards given last year: 1

No. of applicants last year: 10
Additional Information: Late applications will be retained for the next year. The winner will be announced by August 1st. Please see the website for further details.

\section{Otto Klineberg Intercultural and International Relations \\ Award}

Subjects: Intercultural and international relations.

Purpose: To recognize the best paper or article of the year on intercultural or international relations.

Eligibility: Entries can be either unpublished manuscripts, in press papers or books, or papers or books published no more than 18 months prior to the submission deadline. Entries cannot be returned. The competition is open to non-members, as well as members of SPSSI, and graduate students are especially urged to submit papers. The originality of the contribution, whether theoretical or empirical, will be given special weight. Submissions from across the social sciences are encouraged, however the paper must clearly demonstrate its relevance for psychological theory and research in the domain of intercultural and international relations.

Level of Study: Doctorate, Graduate, Postdoctorate, Postgraduate

Type: Prize

Value: US $\$ 1,000$

Frequency: Annual

Country of Study: Any country

No. of awards offered: 1

Application Procedure: The online application form should be completed and sent as an email attachment. For further details visit the website.

Closing Date: March 1st

Funding: Private

No. of awards given last year: 1

No. of applicants last year: 8

Additional Information: Late applications will be retained for the next year. Please see the website for further details.

\section{SPSSI Applied Social Issues Internship Program}

Subjects: The application of social principles to social issues in cooperation with a community or government organization, public interest group or other not-for-profit entity that will benefit directly from the project. Purpose: To encourage research that is conducted in cooperation with a community or government organization, public interest group or other not-for-profit entity that will benefit directly from the project.

Eligibility: Open to college seniors, graduate students and 1st year postdoctorates in psychology, applied social science and related disciplines. Applicants must be SPSSI members.

Level of Study: Graduate, Postdoctorate, Postgraduate

Type: Grant

Value: US $\$ 300-2,500$ to cover research costs, community organiz-

ing, Summer stipends, etc

Frequency: Annual

Country of Study: Any country

No. of awards offered: Varies

Application Procedure: The Application should include: (1) a 3-6 page proposal including the proposed budget and a cover sheet with the applicant's name, address, phone number, email address and title of their proposal. If an intervention is planned, the proposal should carefully describe the theoretical rationale for the intervention,

specifically how the effectiveness of the program will be assessed and the plan to disseminate the findings to relevant parties and policy makers; (2) a short curriculum vitae; (3) a letter from a faculty sponsor/ supervisor of the project, a statement concerning protection for participants if relevant and any funds that the sponsoring organization will use to support the intern's research; (4) a letter from an organizational sponsor (waived if the applicant is proposing to organize a group) that endorses the intern's research activities, describes how the organization will potentially benefit from the work, and outlines any funds the organization will use to support the intern's research.

Closing Date: April 25th

Funding: Private

No. of awards given last year: 1

No. of applicants last year: 5

Additional Information: Late applications will be retained for the next year. Cost sharing by sponsoring department or organization is desirable. Please see the website for further details www.spssi.org/ index.. fm?fuseaction $=$ page . viewpage\&pageid $=637$. 


\section{SPSSI Grants-in-Aid Program}

Subjects: Scientific research in social problem areas related to the basic interests and goals of SPSSI and particularly those that are not likely to receive support from traditional sources.

Purpose: To support scientific research in social problem areas related to the basic interests and goals of SPSSI.

Eligibility: Applicant must be a member of SPSSI. Applicants may submit only one application per deadline. If applied to the Clara Mayo Grant in the same award year he/she is not eligible for GIA. Individuals may submit a joint application.

Level of Study: Doctorate, Graduate, Postdoctorate, Postgraduate Type: Grant

Value: Up to US $\$ 2,000$ for postdoctoral work and up to US $\$ 1,000$ for graduate student research that must be matched by the student's university

Country of Study: Any country

No. of awards offered: Varies

Application Procedure: The Application should include: (1) A cover sheet with the applicant's name, address, phone number, email address and title of the proposal. (2) An abstract of 100 words or less summarizing the proposed research. (3) Project purposes, theoretical rationale, and research methodology and analytical procedures to be employed. (4) Relevance of research to SPSSI goals and Grants-in-Aid criteria. (5) Status of human subjects review process (which must be satisfactorily completed before grant funds can be forwarded).

(6) Curriculum vitae of investigator (a faculty sponsor's recommendation must be provided if the investigator is a graduate student; support is seldom awarded to students who have not yet reached the dissertation stage). (7) Specific amount requested, including a budget. For coauthored submissions, please indicate only one name and institution to which a check should be jointly issued if selected for funding.

Closing Date: May 15th and October 20th

Funding: Private

Contributor: The Sophie and Shirley Cohen Memorial Fund and membership contributions

No. of awards given last year: Approx. 10

No. of applicants last year: Approx. 18

Additional Information: Late applications may be held until the next deadline. Proposals for highly timely and event-oriented research may be submitted at any time during the year to be reviewed within 1 month of receipt on an ad hoc basis. If yours is a time-sensitive application, please indicate that on the outside of the envelope.

For further information contact:

Email: awards@spssi.org

Website: www.spssi.org/index.cfm?fuseaction = page

viewpage\&pageid $=730$

\section{SPSSI Social Issues Dissertation Award}

Subjects: Social issues in psychology or in a social science with psychological subject matter.

Purpose: To encourage excellence in socially relevant research.

Eligibility: Open to doctoral dissertations in psychology (or in a social science with psychology subject matter) accepted between March 1st of the year preceding that of application and March 1st of the year of application. In the award year (July 1st to June 30th) an individual or group may only submit one paper to one SPSSI paper award (amongst Allport, Klineberg and Dissertation awards).

Level of Study: Postgraduate

Type: Prize

Value: First prize of US $\$ 1,000$ and a second prize of US $\$ 500$

Frequency: Annual

Country of Study: Any country

No. of awards offered: 2

Application Procedure: A 500-word summary of the dissertation.

The summary should include title, rationale, methods, and results of dissertation, as well as its implications for social problems. Please also include a cover sheet that states the title of the dissertation,

applicant's name, postal and email addresses, phone number, and university granting the degree.

Closing Date: May 1st

Funding: Private

No. of awards given last year: 2

No. of applicants last year: 15

Additional Information: Online applications are the preferred

method. Applicants will be notified of their status by July. Finalist will be asked to provide certification by the dissertation advisor of the acceptance date of the dissertation and four copies of dissertation. Final decision will be announced by September 1st.

For further information contact:

SPSSI, 208, Washington, DC, 20002-4340, United States of America Website: www.spssi.org/index.cfm?fuseaction $=$ page.

viewpage\&pageid $=724$

\section{THE SOCIETY FOR THE SCIENTIFIC STUDY OF SEXUALITY (SSSS)}

881 Third Street, Suite B-5, Whitehall, PA 18052, United States of America

Tel: (1) 6104433100

Fax: (1) 6104433105

Email: thesociety@sexscience.org

Website: www.sexscience.org

Contact: Mr David L Fleming, Executive Director

The Society for the Scientific Study of Sexuality (SSSS) is an international organization dedicated to the advancement of knowledge about sexuality. The Society brings together an interdisciplinary group of professionals who believe in the importance of both production of quality research and the clinical, educational and social applications of research related to all aspects of sexuality.

\section{FSSS Grants-in-Aid Program}

Subjects: Human sexuality.

Level of Study: Unrestricted

Type: Grant

Value: US $\$ 1,000$ each

Length of Study: 1 year

Frequency: Annual

No. of awards offered: Varies

Application Procedure: For instructions and application guidelines see http://fsssonline.org/grant-instructions/.

Closing Date: February 1st and June 1st

Funding: Foundation

Contributor: The foundation for the scientific Study of sexuality

Additional Information: Preference will be given to research areas unlikely to receive support from other sources. Please see the website for further details www.sexscience.org/honors/fsss_grants_in_aid_ program/.

\section{SSSS Student Research Grants}

Subjects: Human sexuality.

Eligibility: Applicants must be a member of the SSSS.

Level of Study: Doctorate, Postgraduate

Type: Scholarship

Value: US $\$ 1,000$

Length of Study: 1 year

Frequency: Annual

No. of awards offered: 2

Application Procedure: Contact the society or check website for details.

Closing Date: February 1st and June 1st

Funding: Foundation

Contributor: The Foundation for the Scientific study of sexuality

For further information contact:

Email: mlpeters@sexscience.org

Website: www.sexscience.org/student_research_grants

\section{SOCIETY FOR THE STUDY OF FRENCH HISTORY}

School of History \& Archives, Newman Building, University College Dublin, Belfield, Dublin, 4, Ireland Tel: (353) 17168151

Fax: (353) 1334462927

Email: Sandy.Wilkinson@ucd.ie

Website: www.frenchhistorysociety.ac.uk Contact: Dr Sandy Wilkinson, Secretary 
The Society for the Study of French History was established to encourage research into French history. It offers a forum where scholars, teachers and students can meet and exchange ideas. It also offers bursaries for research and conferences to postgraduates in Britain and Ireland undertaking research into French history.

\section{Society for the Study of French History Bursaries}

Subjects: Any aspect of French history.

Purpose: To enable postgraduates undertake research in French history. To enable postgraduates attend conferences concerning French history.

Eligibility: Open to postgraduate students registered at a U.K. or Republic of Ireland university. Students at any level at postgraduate study may apply, provided that their dissertation is on some aspect of French history.

Level of Study: Postgraduate

Type: Bursary

Value: Up to UK£750

Length of Study: Dependent on the project for which the award is given

Frequency: Annual

Country of Study: France

No. of awards offered: Up to 20

Application Procedure: Applicants must give details of the research being pursued and the use to which the money would be put, along with the names of two referees. Applicants are responsible for writing to their referees. Successful applicants will be required to submit, in the first instance, a brief outline of their research proposal and then, after the research trip, a synopsis of their findings, both for publication on the Society's website. Application forms can be downloaded from the Society's website.

Closing Date: March 23rd

Funding: Private

Contributor: The Society for the Study of French History

No. of awards given last year: 11

No. of applicants last year: 13

Additional Information: Please see the website for further details www.frenchhistorysociety.ac.uk/grants.htm.

\section{THE SOCIETY FOR THEATRE RESEARCH}

\author{
c/o National Theatre Archive, 83-101 The Cut, London, \\ SE1 8LL, England \\ Email: e.cottis@btinternet.com \\ Website: www.str.org.uk \\ Contact: Chairman, Research Awards Sub-Committee
}

The Society for Theatre Research was founded in 1948 for all those interested in the history and techniques of British theatre. It publishes annually one or more books, newsletters and three issues of the journal Theatre Notebook, holds lecture meetings and other events, and gives an annual book prize as well as grants for theatre research.

\section{Society for Theatre Research Awards}

Subjects: The history and practice of the British theatre, including music hall, opera, dance and other associated performing arts.

Purpose: To aid research into the history and practice of British theatre.

Eligibility: Applicants should normally be 18 years of age or over, but there is no other restriction on their status, nationality or the location of the research. Undergraduates should not apply.

Level of Study: Unrestricted

Value: $£ 100-2,000$

Frequency: Annual

Country of Study: Any country

No. of awards offered: 2 major awards and a number of lesser awards Application Procedure: Applicants must write to the Chairman of the Research Awards Sub-Committee after October 1st of the preceding year for an application form and guidance notes. All applications and enquiries must be made by post to the Society's accommodation address.

Closing Date: February 7th

Funding: Private

Contributor: Members' subscriptions, donations and bequests

No. of awards given last year: 11
No. of applicants last year: 32

Additional Information: While applicants will need to show evidence of the value of the research and a scholarly approach, they are by no means restricted to professional academics. Many awards, including major ones, have previously been made to theatre practitioners and amateur researchers who are encouraged to apply. The Society also welcomes proposals which in their execution extend the methods and techniques of historiography. In coming to its decisions, the Society will consider the progress already made by the applicants and the possible availability of other grants. Please see the website for further details www.str.org.uk/research/awards/index.html.

\section{SOCIETY OF ACTUARIES}

475 North Martingale Road, Suite 600, Schaumburg, IL, 60173-2226, United States of America

Tel: (1) 8477063500

Fax: (1) 8477063519

Email: eschulty@soa.org

Website: www.soa.org

Contact: Barbara Scott

The Committee on Knowledge Extension research of the Society of Actuaries, the Casualty Actuarial Society and The Actuarial Foundation of Canada carry out research and education projects in actuarial science and study specific projects that could be advanced under this mechanism.

\section{CKER/CAS Individual Grants Competition}

Subjects: Actuarial science.

Purpose: To produce publications that will advance actuarial science, especially with regard to practical applications.

Eligibility: Individuals and groups may apply. Letters of Intent may come from practitioners, usually where the research project is not part of their employment; industry and university researchers; and academics. Graduate and undergraduate students are not eligible to apply individually, but may be part of a group in one of the above categories

Level of Study: Unrestricted

Type: Grant

Value: Varies, approx. US $\$ 10,000-15,000$

Length of Study: Projects should generally be of less than 1 year in duration

Frequency: Annual

Country of Study: Any country

No. of awards offered: Varies

Application Procedure: Applicants must submit a letter of intent and an application form.

Closing Date: Mid-October Annually

Funding: Private

Contributor: The Society of Actuaries and the Casualty Actuarial

Society and individuals

No. of awards given last year: 7

No. of applicants last year: 40

Additional Information: The project may be either theoretical or empirical in nature. A key criteria is that the project should have the potential to contribute significantly to the advancement of knowledge in actuarial science. The Actuarial Foundation, the CAS, the AFC and the SOA give preference to projects relating to current policy issues or having direct applications and those that further the basic or continuing education of actuaries. Proposals for innovative developments in actuarial education are also considered by The Actuarial Foundation, the CAS, the AFC and the SOA. More information is available from the website.

\section{SOCIETY OF ARCHITECTURAL HISTORIANS (SAH)}

1365 North Astor Street, Chicago, Illinois, 60610, United States of America

Tel: (1) 3125731365

Fax: (1) 3125731141

Email: info@sah.org

Website: www.sah.org 
$\mathrm{SAH}$ is an international not-for-profit membership organization that promotes the study and preservation of the built environment worldwide. The Society serves scholars, professionals in allied fields and the interested general public.

Beverly Willis Architecture Foundation Travel Fellowship Subjects: Gender issues in the history of architecture, landscape architecture and associated fields.

Purpose: To advance the status of women in architecture.

Eligibility: Applicants must be members of the SAH.

Level of Study: Doctorate, Postdoctorate

Type: Fellowship

Value: US $\$ 1,500$ travel stipend

Frequency: Annual

Country of Study: United States of America

No. of awards offered: 1

Application Procedure: Apply online.

Closing Date: September 5th (check with website)

\section{Edilia and Francois-Auguste de Montequin Fellowship}

Subjects: Spanish, Portuguese and Ibero-American architecture.

Purpose: To support for travel related to research on Spanish,

Portuguese, or Ibero-American architecture.

Eligibility: Applicants must be members of the SAH.

Level of Study: Postdoctorate, Doctorate

Type: Fellowship

Value: US $\$ 2,000$ for junior scholars awarded each year and

US- $\$ 6,000$ for senior scholars awarded every 2 years

Length of Study: 1 year

Frequency: Every 2 years

No. of awards offered: 2

Application Procedure: Apply online.

Closing Date: September 5th

Funding: Foundation

Contributor: The Auguste de Montequin Foundation

Additional Information: Please see the website for further details.

\section{George R. Collins Fellowship}

Subjects: 19th or 20th century built environment.

Purpose: To enable a scholar to attend the annual meeting of the

Society, held each April.

Level of Study: Doctorate, Postdoctorate, Postgraduate,

Predoctorate

Type: Fellowship

Value: Up to $\$ 1,000$

Frequency: Annual

No. of awards offered: 1

Application Procedure: Applicants must complete an application form, available on request by writing to $\mathrm{SAH}$ for guidelines or visiting the SAH website.

Closing Date: September 5th

Funding: Private

No. of awards given last year: 1

Additional Information: Eligible to nationals of any country except US.

\section{Keepers Preservation Education Fund Fellowship}

Subjects: Historic preservation.

Purpose: To enable a graduate student to attend the annual meeting of the Society, held each April.

Eligibility: Open to members of any nationality who are currently engaged in the study of historic preservation.

Level of Study: Doctorate, Postdoctorate, Postgraduate, Predoctorate

Type: Fellowship

Value: Up to $\$ 1,000$

Frequency: Annual

Country of Study: Any country

No. of awards offered: 1

Application Procedure: Applicants must write to SAH for application guidelines or download an application from the Society's website.

Closing Date: September 5th

Funding: Private

No. of awards given last year: 1

Additional Information: Please see the website for further details.

\section{Rosann Berry Fellowship}

Subjects: Architectural history or an allied field, e.g. city planning, landscape architecture, decorative arts or historic preservation.

Purpose: To enable a student engaged in advanced graduate study to attend the annual meeting of the Society.

Eligibility: Open to persons of any nationality who have been

members of SAH for at least 1 year prior to the meeting, and who are currently engaged in advanced graduate study, normally beyond the Master's level, that involves some aspect of the history of architecture or of one of the fields closely allied to it.

Level of Study: Postdoctorate, Postgraduate

Type: Fellowship

Value: US $\$ 1,000$ travel stipend

Frequency: Annual

Country of Study: Any country

No. of awards offered: 1

Application Procedure: Applicants must complete an application form, available on request by writing to $\mathrm{SAH}$ for guidelines or visiting the SAH website.

Closing Date: September 5th

Funding: Private

No. of awards given last year: 1

Additional Information: Please see the website for further details.

\section{SAH Annual Meeting Fellowships for Scholars}

Subjects: Europe in the 19th and 20th centuries as well as built environments worldwide (other than Europe) from ancient times to the present.

Purpose: To enable senior scholars and graduate students to attend the annual meeting of the society, held each April.

Eligibility: Applicants must be members of the SAH.

Level of Study: Doctorate, Postdoctorate, Postgraduate

Type: Fellowship

Value: Up to US $\$ 1,000$ travel stipend

Frequency: Annual

Country of Study: United States of America

No. of awards offered: 10

Application Procedure: Apply online.

Closing Date: September 5th

Additional Information: Eligible to nationals of any country except US.

\section{SAH Fellowships for Independent Scholars}

Purpose: To enable independent scholars to attend the annual meeting of the Society, held each April.

Level of Study: Postgraduate, Doctorate, Graduate, Postdoctorate

Type: Fellowship

Value: Up to $\$ 1,000$

Frequency: Annual

No. of awards offered: Please check website

Application Procedure: Applicants must complete an application form, available on request by writing to $\mathrm{SAH}$ for guidelines or visiting the SAH website.

Closing Date: August 1st to August 30th

Funding: Private

No. of awards given last year: 2

Additional Information: Please see the website for further details.

\section{SAH Study Tour Fellowship}

Subjects: Internationally significant buildings and sites.

Eligibility: Applicants must be members of the SAH.

Level of Study: Doctorate

Type: Fellowship

Value: Varies

Length of Study: $5-10$ days

Frequency: Annual

No. of awards offered: Varies

Application Procedure: Contact the Society.

Closing Date: Varies, check website

\section{Sally Kress Tompkins Fellowship}

Subjects: Architectural history and historic preservation.

Purpose: To enable an architectural history student to work as an intern on an Historic American Buildings Survey project, during the summer. 
Eligibility: Open to architectural history and historic preservation students.

Level of Study: Doctorate, Postdoctorate, Postgraduate

Type: Fellowship

Value: US\$10,000

Length of Study: 12 weeks

Frequency: Annual

Country of Study: United States of America

No. of awards offered: 1

Application Procedure: Applicants must submit an application including a sample of work, a letter of recommendation from a faculty member, and a U.S. Government Standard Form 171, available from HABS or most U.S. government personnel offices. Applications should be sent to the Sally Kress Tompkins Fellowship. Applicants not selected for the Tomkins Fellowship will be considered for other HABS Summer employment opportunities. For more information, please contact Lisa P. Davidson, HABS/HAER Co-ordinator.

Closing Date: December 31st

Funding: Government

No. of awards given last year: 1

For further information contact:

The Sally Kress Tompkins Fellowship, c/o HABS/HAER, National Park Service, 1201 Eye Street, 7th floor NW, Washington, DC, 20005, United States of America

Tel: (1) 2023542179

Fax: (1) 2023716473

Email: lisa.davidson@nps.gov

Website: www.sah.org/jobs-and-careers/sah-fellowships-and-grants/ research-fellowships

\section{Samuel H. Kress Foundation Fellowships for Speakers}

Subjects: Built environment of Europe from ancient times to the 19th century.

Eligibility: Applicants must be members of the SAH.

Level of Study: Doctorate, Postdoctorate

Type: Fellowship

Value: US\$1,000 travel stipend

Frequency: Annual

Country of Study: United States of America

No. of awards offered: 2

Application Procedure: Apply online.

Closing Date: September 5th

Funding: Foundation

Contributor: Samuel H Kress Foundation

No. of awards given last year: 2

Additional Information: Eligible to nationals of any country except US.

\section{Scott Opler Membership Grant for Emerging \\ Professionals}

Subjects: Architectural history.

Purpose: To support emerging scholars whose papers have been

accepted for delivery at the SAH annual conference.

Eligibility: Applicants must be of the SAH.

Level of Study: Postdoctorate, Postgraduate

Type: Fellowship

Value: Up to $\$ 1,000$ each

Length of Study: 1 year

Frequency: Annual

Country of Study: United States of America

No. of awards offered: 1

Closing Date: August 31st

Additional Information: Please check website.

For further information contact:

Website: www.sah.org/jobs-and-careers/sah-fellowships-and-grants/ research-fellowships

Contact: Kathy Sturm, Meetings and Tours

\section{Spiro Kostof Annual Meeting Fellowship}

Subjects: Architectural history.

Purpose: To enable an advanced graduate student in architectura history to attend the annual meeting of the Society of Architectural Historians.
Eligibility: Open to Doctoral candidates only who have been members of the SAH for at least 1 year.

Level of Study: Doctorate, Predoctorate

Type: Fellowship

Value: US\$1,000 travel stipend

Frequency: Annual

No. of awards offered:

Application Procedure: Applicants must write for an application form, available after June 1st by mail or by visiting the website.

Closing Date: September 5th

Funding: Commercial, private

Contributor: The Society of Architectural Historians

No. of awards given last year: 1

\section{THE SOCIETY OF AUTHORS}

84 Drayton Gardens, London, SW10 9SB England

Tel: (44) 02073736642

Fax: (44) 02073735768

Email: info@societyofauthors.org

Website: www.societyofauthors.org

Contact: The Administration Office

The Society of Authors is a non-profit making organization, founded in 1884 , to protect the rights and further the interests of authors, mainly by giving bursaries, advice and help to members. It administers prizes and grants for authors.

\section{The Authors' Foundation Grants}

Subjects: Fiction or non-fiction.

Purpose: To provide grants to writers to assist them while writing books.

Eligibility: To apply the author must meet either of these conditions: the author has been commissioned by a commercial British publishers to write a work of fiction, poetry or non-fiction and needs funding. The author is without contractual commitment by a publisher but has least one book published already.

Level of Study: Professional development

Type: Grant

Value: $£ 6,000$ max

Length of Study: N/A

Country of Study: United Kingdom

Application Procedure: Please check the website for more details www.societyofauthors.net/grants.

Closing Date: April 30th and September 30th

Funding: Foundation

Contributor: The Authors' Foundation

No. of awards given last year: 65

No. of applicants last year: 183

Additional Information: Editors, translators and screenwriters are not eligible. Specific grants also awarded every 6 months (for which all applicants will automatically be considered).

\section{Great Britain Sasakawa Foundation Grants}

Subjects: Authorship relating to Japanese culture or society.

Eligibility: Preference will be given to authors whose work helps to interpret modern Japan to the English-speaking world.

Level of Study: Professional development

Type: Grant

Value: Up to $£ 4,000$

Length of Study: N/A

Frequency: Annual

Country of Study: United Kingdom

Application Procedure: Contact Paula Johnson at the

Authors' Foundation or check the website for more details

www.societyofauthors.net/grants.

Closing Date: April 30th and September 30th

Funding: Foundation

Contributor: Great Britain Sasakawa Foundation

The K. Blundell Trust Grant

Subjects: Fiction or non-fiction that has the aim of increasing social awareness. 
Purpose: To support British authors under the age of 40 who need funding for important research, travel or other expenditure.

Eligibility: Applicants must be British by birth, resident in the UK, under the age of 40 and their work must contribute to the greater understanding of existing social and economic organization. They must have had one book published.

Level of Study: Professional development

Type: Grant

Value: $£ 1,000-5,000$

Length of Study: N/A

Country of Study: United Kingdom

Application Procedure: See the website for guidelines; submissions by fax or email are not acceptable.

Closing Date: April 30th and September 30th

Funding: Trusts

Contributor: K. Blundell Trust

No. of awards given last year: 6

No. of applicants last year: 10

Additional Information: No author may apply twice to the Trust within one 12-month period; grants will not be awarded to cover publication costs. Please see the website for further details www. societyofauthors.net/grants.

\section{Michael Meyer Award}

Subjects: Writing about the theatre or Sweden.

Eligibility: Please check The Author's Foundation for specific eligibility details for this grant.

Level of Study: Professional development

Type: Grant

Country of Study: United Kingdom

No. of awards offered: 1 in each award period

Application Procedure: Please check the website for more details www.societyofauthors.net/grants.

Closing Date: April 30th and September 30th

Funding: Trusts

Contributor: The late Michael Meyer

No. of awards given last year: 2

\section{Taner Baybars, Roger Deakin, John Heygate, John C \\ Laurence, and Arthur Welton Awards}

Purpose: Taner Baybars - Funding for original fiction in the fields of science fiction, fantasy and magic realism (adult and children's literature). Roger Deakin - Funding to authors of creative works of any genre, concerned with natural history, landscape or the environment. John Heygate - to help authors of commissioned works of travel writing. John C Laurence - to fund works of any genre which help to improve understanding between races. Arthur Welton - in memory of philanthropist and poet Arthur Welton.

Level of Study: Professional development

Value: $£ 3,500-6,000$

Study Establishment: Authors' Foundation, Arthur Welton Trust Closing Date: April 30th and September 30th Funding: Trusts

\section{SOCIETY OF CHILDREN'S BOOK WRITERS AND ILLUSTRATORS (SCBWI)}

8271 Beverly Boulevard, Los Angeles, CA, 90048, United States of America Tel: (1) 3237821010

Fax: (1) 3237821892

Email: scbwi@scbwi.org

Website: www.scbwi.org

Contact: Mr Stephen Mooser, President

The Society of Children's Book Writers and Illustrators (SCBWI) is an organization of 22,000 writers, illustrators, editors, agents and publishers of children's books, television, film and multimedia.

\section{Barbara Karlin Grant}

Subjects: Children's picture books.

Purpose: To assist picture book writers in the completion of a specific project.
Eligibility: Open to both full and associate members of the Society who have never had a picture book published. The grant is not available for a project for which there is already a contract.

Level of Study: Unrestricted

Type: Grant

Value: The full grant is US $\$ 1,500$ and the runner-up grant is US $\$ 500$

Frequency: Annual

Country of Study: Any country

No. of awards offered: 1

Application Procedure: Applicants must write for details.

Closing Date: May 15th

Funding: Private

No. of awards given last year: 2

No. of applicants last year: 75

\section{Don Freeman Memorial Grant-in-Aid}

Subjects: Children's picture books.

Purpose: To enable picture-book artists to further their understanding, training and work in the picture-book genre.

Eligibility: Open to both full and associate members of the Society who, as artists, seriously intend to make picture books their chief contribution to the field of children's literature.

Level of Study: Unrestricted

Type: Grant

Value: The full grant is US $\$ 1,500$ and the runner-up grant is US $\$ 500$

Frequency: Annual

Country of Study: Any country

No. of awards offered: 2

Application Procedure: Applicants must submit an application to the Society. Receipt of the application will be acknowledged.

Closing Date: Application requests should be submitted by June 15th and completed applications should be submitted by February 10th

Funding: Private

No. of awards given last year: 2

No. of applicants last year: 48

\section{SCBWI General Work-in-Progress Grant}

Subjects: Children's literature.

Purpose: To assist children's book writers in the completion of a specific project.

Eligibility: Open to both full and associate members of the Society. The grant is not available for a project for which there is already a contract. Recipients of previous grants are not eligible to apply for any further SCBWI grants.

Level of Study: Unrestricted

Type: Grant

Value: The full grant is US $\$ 1,500$ and the runner-up grant is US $\$ 500$

Frequency: Annual

Country of Study: Any country

No. of awards offered: 1 full grant and 1 runner-up grant

Application Procedure: Applicants must write for details.

Closing Date: May 1st

Funding: Private

No. of awards given last year: 2

No. of applicants last year: 123

\section{SCBWI Grant for a Contemporary Novel for Young People}

Subjects: Children's literature.

Purpose: To assist children's book writers in the completion of a specific project.

Eligibility: Open to both full and associate members of the Society. The grant is not available for a project for which there is already a contract. Recipients of previous grants are not eligible to apply for any further SCBWI Grants.

Level of Study: Unrestricted

Type: Grant

Value: The full grant is US $\$ 1,500$ and the runner-up grant is US $\$ 500$

Frequency: Annual

Country of Study: Any country

No. of awards offered: 1 full grant and 1 runner-up grant

Application Procedure: Applicants must write for details.

Closing Date: May 1st

Funding: Private

No. of awards given last year: 2

No. of applicants last year: 110 


\section{SCBWI Grant for Unpublished Authors}

Subjects: Children's literature.

Purpose: To assist children's book writers in the completion of a specific project.

Eligibility: Open to both full and associate members of the Society who have never had a book published. The grant is not available for a project for which there is already a contract. Recipients of previous grants are not eligible to apply for any further SCBWI Grants.

Level of Study: Unrestricted

Type: Grant

Value: The full grant is US\$1,500 and the runner-up grant is US\$500

Frequency: Annual

Country of Study: Any country

No. of awards offered: 1 full grant and 1 runner-up grant

Closing Date: May 1st

Funding: Private

No. of awards given last year: 2

No. of applicants last year: 45

\section{SCBWI Nonfiction Research Grant}

Subjects: Children's literature.

Purpose: To assist children's book writers in the completion of a specific project.

Eligibility: Open to both full and associate members of the Society. The grant is not available for a project for which there is already a contract. Recipients of previous grants are not eligible to apply for any further SCBWI Grants.

Level of Study: Unrestricted

Type: Grant

Value: The full grant is US\$1,500 and the runner-up grant is US\$500

Frequency: Annual

Country of Study: Any country

No. of awards offered: 1 full grant and 1 runner-up grant

Application Procedure: Applicants must write for details

Closing Date: May 1st

Funding: Private

No. of awards given last year: 1

No. of applicants last year: 75

\section{SOCIETY OF ENVIRONMENTAL TOXICOLOGY AND CHEMISTRY (SETAC)}

229 South Baylen Street, 2nd Floor, Pensacola, FL, 32502, United States of America

Tel: (1) 8504691500

Fax: (1) 8882964136

Email: setac@setac.org

Website: www.setac.org

The Society of Environmental Toxicology and Chemistry (SETAC) is a non-profit, worldwide professional society comprised of individuals and institutions who support the development of principles and practices for protection, enhancement and management of sustainable environmental quality and ecosystem integrity.

\section{Procter \& Gamble Fellowship for Doctoral Research in Environmental Science}

Subjects: Environmental sciences.

Purpose: To promote the advancement and application of scientific research, education in the environmental sciences and the use of science in environmental policy and decision making.

Eligibility: Open to Doctoral students whose research area and academic standing are consistent with the research topics.

Level of Study: Doctorate

Type: Fellowships

Value: US $\$ 15,000$

Length of Study: 1 year

Frequency: Annual

Application Procedure: Applicants must submit electronically a description of the dissertation research, a curriculum vitae and a letter of support from the dissertation director.

Closing Date: September 1st
Additional Information: The award is paid to the recipient's institution, so it is necessary that an authorized representative approve the application on behalf of the institution and certify that none of the award will be spent on overhead.

For further information contact:

Europe Avenue de la Toison d'Or 67 B-1060, Brussels, FL, 32501-

3367, Belgium

Tel: (32) 8504691500

Fax: (32) 8504699978

Contact: Bart Bosveld, Executive Director

\section{SOCIETY OF EXPLORATION GEOPHYSICISTS FOUNDATION (SEG)}

\author{
SEG Foundation PO 702740, Tulsa, OK 74170-2740, \\ United States of America \\ Tel: (1) 9184975500 \\ Fax: (1) 9184975560 \\ Email: scholarships@seg.org \\ Website: www.seg.org \\ Contact: SEG Scholarship Committee
}

The Society of Exploration Geophysicists Foundation (SEG) began a programme of encouraging the establishment of scholarship funds by companies and individuals in the field of geophysics in 1956. It is a merit based programme focused on geophysics.

\section{Geoscientists Without Borders}

Subjects: Geophysics.

Purpose: To encourage and support scientific, educational and charitable activities of benefit to the general public, to geophysicists and to the geophysical community.

Value: Maximum US $\$ 50,000$ per year

Length of Study: 1 or 2 year duration

Frequency: Annual

Application Procedure: Two phase application process. Phase I: (LOI) Project summary (twice a year) if selected it goes into phase II Phase II: More detailed project description.

Closing Date: February 20th

Funding: Corporation, individuals

Contributor: SEG Foundation

Additional Information: Please see the website for further details www.seg.org/web/foundation/programs/geoscientists-withoutborders.

\section{SEG Scholarships}

Subjects: Applied geophysics and related fields.

Purpose: To encourage careers in applied geophysics and related fields.

Eligibility: Open to citizens of any non-sanctioned country who are entering undergraduate or graduate level and have above average grades and an aptitude for geophysics.

Level of Study: Doctorate, Graduate, Undergraduate

Type: Scholarship

Value: US $\$ 500-14,000$ per academic year. Average awards are approx. US $\$ 2,500$

Length of Study: 1 academic year, may be eligible for renewal

Frequency: Annual

Country of Study: Any country

No. of awards offered: Varies

Application Procedure: Applicants must submit a completed application form accompanied by latest transcripts and 2 letters of recommendation from faculty members who are familiar with the applicant's academic work.

Closing Date: March 1st of the year in which the award is made Funding: Private, commercial, corporation, individuals, trusts No. of awards given last year: 119

No. of applicants last year: 600

Additional Information: More than US $\$ 400,000$ was granted in scholarships during the last academic year. Please see the website for further details www.seg.org/web/foundation/programs/ scholarship. 


\section{SOCIETY OF ORTHOPAEDIC MEDICINE}

\author{
PO Box 204, Woolton, L25 7WA, England \\ Tel: (44) 1454610255 \\ Email: admin@soc-ortho-med.org \\ Website: www.soc-ortho-med.org \\ Contact: Administrative Director
}

The Society of Orthopaedic Medicine is a non-profit making organization offering grants for work within musculoskeletal medicine.

\section{SOM Research Grant}

Subjects: Musculoskeletal and orthopaedic medicine.

Purpose: To assist those undertaking programmes of study that will increase knowledge in the field of orthopaedic medicine and enhance their professional development.

Eligibility: Applications are considered from those undertaking one of the following, where there is an explicit link to musculoskeletal medicine: A research degree leading to BSc, MSc, MPhil or $\mathrm{PhD} /$ DProf, pilot study, student project leading to BSc, presentation at a conference.

Level of Study: Graduate, Postdoctorate, Predoctorate, Professional development

Value: Up to UK£5,000. UK£2,000 of this allocation will be available in the form of smaller grants of up to UK£500

Frequency: Annual

Country of Study: United Kingdom

No. of awards offered: Varies according to funds

Application Procedure: Applicants must complete an application form available from the organization.

Closing Date: July 23rd

Funding: Commercial

No. of awards given last year: 5

No. of applicants last year: 8

\section{SOCIETY OF WOMEN ENGINEERS (SWE)}

203 N. La Salle Street, Suite 1675, Chicago, IL, 60601, United States of America

Tel: (1) 8777934636

Fax: (1) 3125965252

Email: hq@swe.org

Website: www.swe.org

Contact: Ms Karen Horting, Executive Director

The Society of Women Engineers (SWE) was founded in 1950, and is a non-profit educational service organization. SWE is the driving force that establishes engineering as a highly desirable career aspiration for women. SWE empowers women to succeed and advance in those aspirations and be recognized for their life-changing contributions and achievements as engineers and leaders.

\section{Society of Women Engineers Scholarships}

Subjects: The SWE Scholarship program provides financial assistance to women admitted to accredited baccalaureate or graduate programs, in preparation for careers in engineering, engineering technology and computer science.

Eligibility: Please check website for requirements and eligibility at www.SWE.org/scholarships.

Level of Study: Doctorate, Graduate

Type: Scholarship

Value: $\$ 1,000-15,000$

Country of Study: United States of America

No. of awards offered: Varies

Application Procedure: Apply online at website.

Closing Date: For sophomores through graduate students: December 1 - February 17 and For freshmen: March 1 - May 15 Funding: Corporation, foundation

No. of awards given last year: 25 awards to masters and $\mathrm{PhD}$ students

No. of applicants last year: 3,700 total in 2014 or 1,500 sophomore through $\mathrm{PhD}$
SOCRATES SCULPTURE PARK

PO Box 6259, 32-01 Vernon Boulevard, Long Island City, NY, 11106, United States of America

Tel: (1) 7189561819

Fax: (1) 7186261533

Email: info@socratessculpturepark.org

Website: www.socratessculpturepark.org

Socrates Sculpture Park was an abandoned riverside landfill and illegal dumpsite until 1986 when a coalition of artists and community members, under the leadership of artist Mark di Suvero, transformed it into an open studio and exhibition space for artists and a neighbourhood park for local residents. Today it is an internationally renowned outdoor museum and artist residency programme that also serves as a vital New York City park offering a wide variety of public services.

\section{Socrates Sculpture Park Emerging Artist Fellowship Program \\ Subjects: Sculpture.}

Purpose: To provide artists with opportunities to create and exhibit large-scale work in a unique environment that encourages strong interaction between artists, artworks and the public.

Eligibility: Open to artists who are not yet well established, are New York State residents and are in need of financial assistance.

Level of Study: Professional development

Type: Fellowship

Value: US $\$ 5,000$

Length of Study: Please check website http://socratessculpturepark. org/exhibition/eaf14/

Frequency: Annual

Country of Study: United States of America

No. of awards offered: 15

Application Procedure: Applicants can download the application form from the website. The completed application form along with a curriculum vitae, references, slide script and proposal must be submitted.

Closing Date: January 7 th

Additional Information: Grants and fellowships are not available to artists who are enroled in a school, college or university programme. Please see the website for further details.

\section{SODERTORN UNIVERSITY}

SE-141 89 Huddinge, Sweden

Contact: Södertörn University Registrator

Sodertorn University is a public university located in Flemingsberg, which is located in Huddinge Municipality, and the larger area called Södertörn, in Stockholm County, Sweden. In 2013, it had about 13,000 full-time students.

\section{Södertörn University Tuition Fee Waive}

Subjects: Scholarships are awarded to study the subjects offered by the university.

Purpose: Sodertorn University is offering tuition fee waiver for pursuing master's programme studies.

Eligibility: Students who have applied for a one or two-year Master's programme at Södertörn University may submit an application for a tuition fee waiver.

Level of Study: Postgraduate

Length of Study: 1 to 2 years

Country of Study: Sweden

No. of awards offered: Not known

Application Procedure: Send the application form along with necessary supporting documents to the following email address: registrator@sh.se.

Closing Date: March 10th

\section{SOIL AND WATER CONSERVATION SOCIETY (SWCS)}

945 SW Ankeny Road, Ankeny, IA, 50023, United States of America Tel: (1) 5152892331

Fax: (1) 5152891227

Email: swcs@swcs.org

Website: www.swcs.org 
The Soil and Water Conservation Society (SWCS) fosters the science and the art of soil, water and related natural resource management to achieve sustainability. The SWCS promotes and practices an ethic recognizing the interdependence of people and the environment.

\section{The Kenneth E. Grant Scholarship}

Subjects: Soil science, water science and related natural resource management.

Purpose: To actively promote multi-disciplinary research

Eligibility: An applicant for the research scholarship must: be a member of SWCS for at least 1 year by the scholarship due date, as recognized by headquarters; have demonstrated integrity, ability, and competence to complete the specified study topic; be eligible for graduate work at an accredited institution; and show reasonable need for financial assistance.

Level of Study: Postgraduate

Type: Scholarship

Value: US $\$ 1,300$

Length of Study: 1 year

Frequency: Annual

No. of awards offered: 1

Application Procedure: The scholarship application can be filled out and submitted electronically at https://swcs.formstack.com/forms/ 2015_kenneth_e_grant_research_scholarship_application. All supplemental materials can be uploaded during the online application process or you can mail or email the materials to Soil and Water Conservation Society.

Closing Date: February 12th

For further information contact:

Email: awards@swcs.org

Website: www.swcs.org/en/members_only/scholarships/

\section{SONS OF THE REPUBLIC OF TEXAS}

1717 8th Street, Bay City, TX, 77414, United States of America Tel: (1) 9792456644

Fax: (1) 9792443819

Email: srttexas@srttexas.org

Website: www.srttexas.org

Contact: Janet Knox, Administrative Assistant

Sons of the Republic of Texas seeks to perpetuate the memory and spirit of the men and women who settled Texas and won its independence through great personal sacrifice and dedication to the cause of freedom.

\section{Presidio La Bahia Award}

Subjects: History.

Purpose: To promote the suitable preservation of relics, appropriate dissemination of data and research into Texas heritage, with particular emphasis on the Spanish colonial period.

Eligibility: Open to all persons interested in the Spanish colonial influence on Texas culture.

Level of Study: Unrestricted

Type: Award

Value: The 1st prize is a minimum of US $\$ 1,200$, and the $2 \mathrm{nd}$ and $3 \mathrm{rd}$ prizes are the divided balance from the total amount available of US $\$ 2,000$ at the discretion of the judges

Frequency: Annual

Study Establishment: Any suitable institution

Country of Study: Any country

No. of awards offered: 3

Application Procedure: Applicants must submit four copies of published writings to the office. Galley proofs are not acceptable. Closing Date: Entries are accepted from June 1st to September 30th Funding: Private

No. of awards given last year: 1

Additional Information: Research writings have, in the past, proved to be the most successful type of entry. However, consideration will be given to other literary forms, art, architecture and archaeological discovery. For projects other than writing, contestants should furnish a description of the proposed entry, so that the Chairman may issue specific instructions.

\section{Summerfield G Roberts Award}

Subjects: History.

Purpose: To encourage literary effort and research about historical events and personalities during the days of the Republic of Texas 1836-1846, and to stimulate interest in the period.

Eligibility: Open to all writers.

Level of Study: Unrestricted

Type: Award

Value: US $\$ 2,500$

Frequency: Annual

Study Establishment: Any suitable institution

Country of Study: Any country

No. of awards offered: 1

Application Procedure: Manuscripts must be written or published during the calendar year for which the award is given. There is no word limit. No entry may be submitted more than one time. The manuscripts must be mailed ( 5 copies, for the use of the judges) to the General Office of the Sons of the Republic of Texas.

Closing Date: January 15th

Funding: Private

No. of awards given last year: 1

Additional Information: The award was made possible through the generosity of Mr and Mrs Summerfield G Roberts.

\section{THE SOROPTIMIST FOUNDATION OF CANADA}

87 East Tree Drive, Breslau, Ontario, ON, NOB 1M0, Canada Email: chair@soroptimistfoundation.ca Website: www.soroptimistfoundation.ca Contact: Aline Chan, Treasurer

The Soroptimist Foundation was established in 1963 by incorporation under the laws of Canada, for charitable, scientific, literary and educational purposes.

\section{Soroptimist Foundation of Canada Grants for Women} Subjects: All subjects.

Purpose: To financially assist women who wish to complete graduate studies for careers that will improve the quality of the lives of women and girls.

Eligibility: Open only to women candidates who are citizens or landed immigrants of Canada enrolled in an accredited Canadian university and will work in Canada for a minimum of 2 years after completion of the degree course.

Level of Study: Postgraduate

Type: Grant

Value: Canadian $\$ 7,500$

Frequency: Annual

Country of Study: Canada

No. of awards offered: 4

Application Procedure: Applicants must send completed application forms and all required additional documents before the closing date. Please see the website www.soroptimistfoundation.ca/application. htmll for further details.

Closing Date: January 31st each year

Funding: Foundation

No. of awards given last year: 4

No. of applicants last year: 110

For further information contact:

For Western Canada: 3107 Highland Boulevard, North Vancouver, BC, V7R 0X5

Contact: Jean Violette

\section{THE SOUTH AFRICAN INSTITUTE OF INTERNATIONAL AFFAIRS (SAIIA)}

Jan Smuts House, PO Box 31596, Johannesburg, Braamfontein, 2017, South Africa

Tel: (27) 113392021

Fax: (27) 113392154

Email: info@saiia.org.za

Website: www.saiia.org.za

Contact: Mr Jonathan Stead, Director of Operations 
The South African Institute of International Affairs (SAlIA) is an independent, non-governmental foreign policy think tank, whose purpose is to encourage wider and more informed interest in international affairs and public education and to focus on policyrelevant research.

\section{SAllA Bradlow Fellowship}

Subjects: Social and behavioural sciences.

Purpose: To provide travel costs and a stipend to enable a senior scholar to reside at the Institute in order to research a subject of importance to South Africa's international relations.

Eligibility: Open to senior scholars.

Level of Study: Research

Type: Fellowship

Value: The stipend covers living expenses and a return economyclass airfare from the candidate's place of residence. The successful fellow will have access to SAIIA's research network and will participate in the events and research programme of the institute

Length of Study: 3-6 months

Frequency: Annual

Study Establishment: SAIIA

Country of Study: South Africa

No. of awards offered: 1

Application Procedure: Applicants must send a curriculum vitae including a short research proposal of not more than 1,000 words to the Director of Studies.

Funding: Private

Contributor: The Bradlow Foundation

No. of awards given last year: 1

Additional Information: Please refer to the website for further details: www.saiia.org.za/opportunities/internship-fellowshipopportunity-bradlow-fellowship.

SAIIA Konrad Adenauer Foundation Research Internship Subjects: Politics, international relations, journalism and economics. Purpose: To enable research interns to enrol at the University of Witwatersrand for a Master's degree by coursework while simultaneously working at SAIIA.

Eligibility: Open to South African citizens under 30 years of age. Level of Study: Postgraduate

Type: Internship

Value: Full bursary for tuition fees and a monthly stipend to cover living costs and accommodation

Length of Study: 10 months

Frequency: Annual

Study Establishment: SAIIA and the University of Witwatersrand Country of Study: South Africa

No. of awards offered: 3

Application Procedure: Applicants must send a curriculum vitae, names and contact details of three referees, letter of motivation, outline of research interests in the field of international relations, three written references, June results and academic transcripts of previous degree and one example of written work not exceeding 3,000 words on a topic of choice.

Closing Date: October 8th

Funding: Foundation

Contributor: Konrad Adenauer Foundation

No. of awards given last year: 2

No. of applicants last year: 32

For further information contact:

Email: grobbelaarn@saiia.wits.ac.za

\section{SOUTH AFRICAN MEDICAL RESEARCH COUNCIL (SAMRC)}

Francie van Zijl Drive, Parowvallei, Cape, PO Box 19070, Tygerberg, 7505, South Africa

Tel: (27) 219380911

Fax: (27) 219380200

Email: info@mrc.ac.za

Website: www.mrc.ac.za

Contact: Mrs Marina Jenkins, Research Grants Administration
The South African Medical Research Council's (SAMRC) brief is to undertake excellent research, which can be implemented to improve the health of all South Africans. Research priorities are regularly established through broad consultation. The SAMRC's mission is to improve the health, status and quality of life of the nation through excellence in scientific research.

\section{SAMRC Local Postdoctoral Scholarships}

Subjects: Health sciences.

Purpose: To create opportunities for recent postdoctoral scientists who are otherwise lost to the system and country.

Eligibility: Open to candidates who have completed a Doctorate research in any field in the health sciences.

Level of Study: Postdoctorate

Type: Scholarships

Value: 1st year postdoctoral scientist - R80,000 pa tax free (can be supplemented to a maximum of R120,000); 2nd year postdoctoral scientist - R90,000 pa tax free (can be supplemented to a maximum of R135,000); 3rd year postdoctoral scientist - R100,00 pa tax free (can be supplemented to a maximum of R150,000)

Length of Study: 3 years

Frequency: Annual

Country of Study: South Africa

Application Procedure: Applicants must submit a research plan, institutional and ethics approval for the project, proof of source of funding for the research project and 3 referees reports.

Closing Date: August 31st

Additional Information: Please see the website for further details www.mrc.ac.za/researchdevelopment/localpostdocscholar.htm.

\section{SAMRC Post MBChB and BChD Grants}

Subjects: Health sciences.

Purpose: To provide an opportunity for full-time research training for medical doctors as part of their development towards a Master's degree.

Eligibility: Open to recent MBChB or BChD graduates who are registered with the health professions council and have completed their internship and community service and registered for a Master's degree in a specialist field or a research area.

Level of Study: Postgraduate

Type: Grant

Value: Rand 80,000 per year

Length of Study: 4 years

Frequency: Annual

Country of Study: South Africa

Application Procedure: Applicants must submit their applications to the MRC through the institution's postgraduate bursary office.

Closing Date: June 30th

Additional Information: Please see the website for further details www.mrc.ac.za/researchdevelopment/postscholar1.htm.

\section{SOUTHEAST ASIA URBAN ENVIRONMENTAL MANAGEMENT APPLICATIONS (SEA-UEMA)}

School of Environment, Resources and Development, Asian Institute of Technology PO Box 4, Klong Luang, Pathumthani, 12120, Thailand Tel: (66) 025245777

Fax: (66) 025162126,5248338

Email: uemapplications@ait.ac.th

Website: www.sea-uema.ait.ac.th

The Canadian International Development Agency and the Asian Institute of Technology have entered into a contribution agreement on urban environmental management. This is in the form of Southeast Asia Urban Environmental Management Applications (SEA-UEMA) Project, which aims to improve the urban environmental management policies and good practices in the region.

\section{SEA-UEMA Postdoctoral Research Fellowships}

Subjects: Urban environmental management practices and policies. Purpose: To contribute to the improvements of urban environmental conditions in Southeast Asia. 
Eligibility: Open to candidates from the Canadian ODA eligible Southeast Asian countries who hold a Doctoral degree.

Level of Study: Postdoctorate

Type: Fellowships

Value: Baht 50,000 per month plus Baht 150,000 as research fund and other benefits

Length of Study: 1 year

Frequency: Annual

Application Procedure: Applicants must submit an application form along with curriculum vitae, reprints of publications and a research proposal.

Closing Date: July 15th

Additional Information: For further inquiries please contact Mr Vikas Nitivattaranon, Assistant Professor. Email: bimal@ait.ac.th; Tel: 02 5246399 .

\section{SOUTHERN AFRICAN MUSIC RIGHTS ORGANIZATION (SAMRO) ENDOWMENT FOR THE NATIONAL ARTS}

PO Box 31609, Johannesburg, Braamfontein, 2017, South Africa

Tel: (27) 117128000

Fax: (27) 114031934

Email: customerservices@samro.org.za

Website: www.samro.org.za

Contact: J C Otto, Liaison \& Research Officer

Southern African Music Rights Organization (SAMRO) is Southern Africa's society of composers and lyricists, administering the performing, transmission and broadcasting rights in the musical works of its members and the members of its affiliated societies. Through the SAMRO Endowment for the National Arts (SENA), it encourages the development of the arts by combining funding with support and advisory services to individuals and organizations to enable them to further their music education, composer careers and more.

\section{SAMRO Intermediate Bursaries for Composition Study In Southern Africa}

Subjects: Music.

Purpose: To support music composition study as a major subject in either the western art, choral or jazz popular music genres.

Eligibility: Open to citizens of South Africa, Botswana, Lesotho and Swaziland who have met the requirements for proceeding to the $3 \mathrm{rd}$ 4th or honours year of a senior undergraduate degree or equivalent diploma course. Applicants must have been born after February 15th, 1974. For those entering any year of a Master's or doctoral degree, the age limit is 32 . Older students are considered in special circumstances.

Level of Study: Postgraduate

Type: Bursary

Value: Varies

Length of Study: 1 year

Frequency: Annual

Study Establishment: A university, institute of technology or other recognized statutory institute of tertiary education approved by the trustees

Country of Study: South Africa, Botswana, Lesotho, or Swaziland No. of awards offered: 7

Application Procedure: Applicants must complete an application form.

Closing Date: March 1st

Funding: Private

Contributor: SAMRO

No. of awards given last year: 4

No. of applicants last year: 5

Additional Information: Applicants must produce an official letter of acceptance for entering any year of a Master's or doctoral degree. Please see the website for further details www.samro.org.za/ node $/ 4570$

\section{SAMRO Overseas Scholarship}

\section{Subjects: Music}

Purpose: To encourage music study at the postgraduate level in the western art/choral or jazz popular music genres.
Eligibility: Open to postgraduate students who are citizens of South Africa, Botswana, Lesotho or Swaziland. The age limit is 34 years.

Level of Study: Postgraduate

Type: Scholarship

Value: Rand 160,000 plus travel expenses of up to Rand 10,000

Length of Study: 2 years

Frequency: Annual

Study Establishment: An institute or educational entity approved by the SAMRO Endowment for the National Arts (SENA)

Country of Study: United Kingdom, Europe or North America

No. of awards offered: 2

Application Procedure: Applicants must complete an application form.

Closing Date: May 31st

Funding: Private

Contributor: SAMRO

No. of awards given last year: 2

No. of applicants last year: 13

Additional Information: Please see the website for further details.

For further information contact:

Tel: $0117128444 / 0117128417$

Email: anriette.chorn@samro.org.za

Contact: Anriette Chorn

\section{SAMRO Postgraduate Bursaries for Indigenous African}

Music Study

Subjects: Music.

Purpose: To encourage the study of indigenous African music at the postgraduate level in either the traditional, western art/choral or jazz popular music genres.

Eligibility: Open to postgraduate students who are citizens of South Africa, Botswana, Lesotho or Swaziland. The age limit is 40 years.

Level of Study: Postgraduate

Type: Bursary

Value: Rand 5,500

Length of Study: 5 years

Frequency: Annual

Study Establishment: A university or other recognized statutory institute of tertiary education approved by the trustees and situated in SAMRO's current territory of operation

Country of Study: South Africa, Botswana, Lesotho, or Swaziland No. of awards offered: 6

Application Procedure: Applicants must complete an application form.

Closing Date: March 1st

Funding: Private

Contributor: SAMRO

No. of awards given last year: 4

No. of applicants last year: 5

Additional Information: Applicants must produce an official letter of acceptance from a recognized tertiary institute of learning. They must have acceptance into the 1 st year or any subsequent year of a postgraduate degree in indigenous African music at such an institute.

For further information contact:

Samro Endowment for the National Arts, PO Box 31609,

BRAAMFONTEIN, 2017

Tel: 0114895000

Fax: 0114031934

Email: sena@samro.org.za

Website: www.samro.org.za/node/4570

\section{SOUTHERN AFRICAN-NORDIC CENTER (SANORD)}

SANORD Central Office, University of the Western Cape Private Bag x17, Bellville, ZA, 7535, South Africa Website: www.sanord.net/

The Southern African-Nordic Centre is a non-profit membership organization of institutions of higher education and research for all Nordic countries and southern Africa. 


\section{Brain O'Connell (BOC) Partial Scholarship}

Subjects: The Partial Scholarship Funding Programme of SANORD has been renamed the 'Brian O'Connell Partial Scholarship Programme' in honour of the major contributions Prof O'Connell has made to SANORD over the years. SANORD is making available partial scholarship opportunities for students from the Southern Africa institutions of higher education and research. Successful students will be required to spend 3 to 5 months at a Nordic (Norway, Sweden, Finland, Iceland or Denmark) SANORD member institution in order to engage in activities that will support the completion of the students Master's degree.

Purpose: SANORD is making available partial scholarship opportunities for students from the Southern Africa institutions of higher education and research.

Eligibility: Enrolled for mainly Master's degrees at a SANORD member, Southern African institution. Must be willing to enhance their knowledge in order to make a contribution toward the development of Southern Africa. The applicant must liaise with the SANORD Coordinator at the host university and provide a written communication of acceptance from a host university.

Level of Study: Postgraduate

Length of Study: Successful students will be required to spend 3 to 5 months at a Nordic (Norway, Sweden, Finland, Iceland or Denmark) SANORD member institution in order to engage in activities that will support the completion of the students' Master's degree

No. of awards offered: Varies

Application Procedure: Please check website for more details.

Closing Date: September 30th

\section{SPACE ENVIRONMENT RESEARCH CENTRE (SERC)}

\author{
Brisbane St Lucia, QLD 4072, Australia \\ Tel: +61733651111 \\ Contact: The University of Queensland
}

\section{Space Environment Research Centre Scholarships}

Subjects: Mathematics, physics, dynamic database management, engineering, adaptive optics, astrodynamics, atmospheric sciences, geodesy, geomatics, laser engineering, laser guide star adaptive optics, laser physics, satellite positioning, space sciences and space tracking. Purpose: The CRC for Space Environment Management (SEMCRC), managed by the Space Environment Research Centre (SERC) has been established to build on Australian and international expertise. Students can receive additional support and opportunities provided by the Space Environment Research Centre. Successful scholarship candidates will also have the opportunity to apply for exciting short-term placements in space research centres internationally and within Australia.

Eligibility: Consideration of all candidates will be given based on academic merit, relevance of studies to SERC objectives and potential for long-term contribution to research outcomes. Priority is given to students with first class honours (or equivalent) from participating countries, currently Australia, Japan and the USA.

Level of Study: Graduate, Postgraduate

Frequency: All year round

Application Procedure: To apply please visit: serc.org.au/students Closing Date: 31 December

Additional Information: The applicant is or will be enrolled in academic studies at a reputable Australian University. In the case of an international applicant, the applicant is required to have a valid passport, appropriate visa and may not be from a country subject to Trade Controls.

\section{THE SPENCER FOUNDATION}

625 North Michigan Avenue Suite 1600, Chicago, IL, 60611, United States of America

Tel: (1) 3123377000

Fax: (1) 3123370282

Email: abrinkman@spencer.org

Website: www.spencer.org

Contact: Annie Brinkman, Grant Manager

The Spencer Foundation was established in 1962 by Lyle M. Spencer The Foundation is committed to supporting high quality investigation of education through its research programmes and to strengthening and renewing the educational research community through its fellowship and training programmes and related activities.

\section{Spencer Foundation Dissertation Fellowship Program}

Subjects: Education.

Purpose: To encourage a new generation of scholars from a wide range of disciplines and professional fields to undertake research relevant to the improvement of education.

Eligibility: Open to candidates for the Doctoral degree at a graduate school within the US.

Level of Study: Doctorate

Type: Fellowship

Value: US $\$ 25,000$

Frequency: Annual

Country of Study: United States of America

No. of awards offered: Up to 25

Application Procedure: Applicants must apply online. In addition to the completed application form they must submit a list of publications presentations, a dissertation abstract, a narrative discussion of the dissertation, a work plan, 2 letters of recommendation and a graduate transcript.

Closing Date: October 27th

Additional Information: Please see the website for further details www.spencer.org/content.cfm/fellowship-awards.

For further information contact:

Email: fellows@spencer.org

\section{ST VINCENT'S INSTITUTE (SVI)}

\author{
41 Victoria Parade, Fitzroy, VIC 3065, Australia \\ Tel: (61) 0392312480 \\ Fax: (61) 0394162676 \\ Email: grantsadmin@svi.edu.au \\ Website: www.svi.edu.au \\ Contact: Dr Rachel Mudge, Grants Officer
}

St Vincent's Institute (SVI) conducts programs of basic and clinical research into diseases that have a high impact on the community and is focused on exploring both disease causes and prevention, with a commitment to discovering practical and far-reaching solutions to diseases that impact on the everyday life of people around the world.

\section{SVI Foundation Postgraduate Student Award}

Subjects: Medical research.

Purpose: To provide valuable financial support for outstanding students commencing their $\mathrm{PhD}$ training at SVI.

Eligibility: Open to First Class (Honours) students commencing full time study towards a PhD at St Vincent's Institute. Students need to successfully apply for a full PhD stipend (APA, Dora Lush etc.) to be eligible for this award. This is intended to be a top up award for those students receiving full $\mathrm{PhD}$ scholarships.

Level of Study: Doctorate, Graduate

Type: Award

Value: $\$ 5,000$ per year

Length of Study: 3 years

Frequency: Annual

Study Establishment: St Vincent's Institute

Country of Study: Australia

No. of awards offered: Up to 2

Application Procedure: Check website for further details.

Closing Date: October 31st

Funding: Foundation

No. of awards given last year: 2

No. of applicants last year: 7

Additional Information: Scholarships will be awarded on the basis of the applicant's academic excellence and research potential. An interview with the selection panel may be required.

\section{STANFORD UNIVERSITY}

450 Serra Mall, Stanford, CA, 94305-2004, United States of America Tel: (1) 6507232300

Website: www.stanford.edu 
Stanford University, located between San Francisco and San Jose in the heart of California's Silicon Valley, is one of the world's leading teaching and research universities. Since its opening in 1891 Stanford has been dedicated to finding solutions to big challenges and to preparing students for leadership in a complex world.

\section{John S. Knight Journalism Fellowships}

Subjects: Journalism.

Eligibility: U.S. applicants for a Knight Fellowship ideally have at least 7 years of full-time professional experience, international applicants ideally have at least 5 years. But the fellowship program also consider less experienced applicants with outstanding achievements. No college degree is required. It is open to applicants who are full-time journalists; journalism entrepreneurs and innovators; journalism business and management executives.

Type: Fellowship

Value: It provides several financial benefits including stipend of

$\$ 65,000$ (paid in 10 monthly installments), tuition fee (paid directly to Stanford); books, research and equipment allowance $(\$ 4,000$ which may be used for laptops, digital cameras, recorders, software, books, research fees or payments, web design, fees for non-Stanford courses and workshops and travel expenses related to the fellow's innovation proposal); housing supplement (total for the year); childcare supplement; health insurance supplement; moving supplement. For detailed information, please visit website

Frequency: Annual

Country of Study: United States of America

Application Procedure: The mode of applying is online.

Closing Date: December 1st

Contributor: Stanford University

Additional Information: Each year, 20-plus journalists from all over the world come together for 10 months of learning, collaborating, creating and fun.

\section{Postdoctoral Fellowship in Literary Cultures of Muslim South Asia}

Eligibility: Candidates must specialize in literary or cultural studies connected to a major language of South Asian Muslim literary production such as Urdu-Hindi, Persian, or Bengali. The position is open to scholars in any historical period. Disciplinary training may be in area studies (South Asia or Near East), anthropology, comparative literature, history, or religious studies. All applicants must have completed the PhD by the time of appointment.

Type: Fellowship

Value: Annual salary of $\$ 55,000-60,000$ and health coverage and $\$ 1,500$ for research-related expenses

Application Procedure: Application materials must be submitted online at https://secure.interfolio.com/apply/20918. Applicants must submit a cover letter, curriculum vitae, one-page description of research plans, and drafts of two course syllabi. Applicants must also arrange for two letters of recommendation to be uploaded directly by the letter writers.

Closing Date: January 15th

Additional Information: The postdoctoral fellow will teach two courses over three academic quarters related to his/her interests, pursue his/her own research, and participate in the activities of Stanford University programs and departments. Review of applications will begin on February 28th. For detailed information, please check website.

\section{THE STANLEY MEDICAL RESEARCH INSTITUTE}

8401 Connecticut Avenue, Suite 200, Chevy Chase, MD, 20815, United States of America

Tel: (1) 3015710760

Fax: (1) 3015710769

Email: marter@stanleyresearch.org

Website: www.stanleyresearch.org

Contact: Ms Rhoda Marte

SMRI is a nonprofit organization that supports research designed to find better treatments for schizophrenia and bipolar disorder.

Approximately 75 per cent of its annual expenditures are devoted to the direct clinical testing of new treatments. 25 per cent is earmarked for research on the causes of these illness.

\section{Stanley Medical Research Institute Postdoctoral} Research Fellowship Program

Subjects: Psychiatry and mental health-causes and treatment of schizophrenia and bipolar disorder.

Purpose: To attract top-quality scientists to specific areas of research in severe mental illness.

Eligibility: Open to researchers worldwide. Applicants must be a doctorate or equivalent professional and must not be more than

2 years past receipt of their doctoral degree.

Level of Study: Postdoctorate, Research

Type: Research fellowship

Value: Up to US $\$ 150,000$ spread over 2 years including indirect costs of up to 15 per cent as part of the total grant budget

Length of Study: 2 years

Frequency: Annual

Country of Study: Any country

No. of awards offered: 1

Application Procedure: Interested applicants must apply online at the website. Detailed instructions for application are available in a printable format (PDF).

Closing Date: January 15th

Funding: Foundation, individuals

Additional Information: Top priority will be given to applications that address the following questions: (1) Synthesis or screening of compounds to be tested against molecular targets identified for severe mental illness (schizophrenia, bipolar disorder, severe depression)

(2) Pharmacokinetic and toxicological characterization of potential drugs for severe mental illness. (3) Ethnopharmacology, i.e., discovery or characterization of potentially useful psychoactive compounds from non-Western medical traditions.

\section{Stanley Medical Research Institute Research Grants Program}

Subjects: Psychiatry and mental health: causes and treatment of schizophrenia and bipolar disorder.

Purpose: To support researchers at all levels of development in fields related to the cause and treatment of schizophrenia and bipolar disorder, as well as from other areas of medicine and biology who wish to initiate new projects in this field.

Eligibility: Open to researchers worldwide. Applicants must be a doctorate or equivalent professional.

Level of Study: Research

Type: Research grant

Value: upto $\$ 300,000$

Length of Study: 2 years

Frequency: Annual

Country of Study: Any country

Application Procedure: Interested applicants must apply online at the SMRI website. Detailed instructions for application are available in a printable format (PDF).

Closing Date: March 1st

Funding: Foundation, individuals, private

\section{Stanley Medical Research Institute Treatment Trial Grants Program}

Subjects: Psychology and mental health: treatments for schizophrenia and bipolar disorder.

Purpose: To support researchers and facilitate the direct testing of new treatments for schizophrenia and bipolar disorder. This programme supports projects involving human subjects and testing a therapeutic intervention (medication; device; putative medication including plant substances and nutritional; psychotherapy).

Eligibility: Open to researchers worldwide. Applicants must be a Doctorate or equivalent professional.

Level of Study: Research

Type: Research grant

Value: US $\$ 300,000$ per year

Length of Study: 3 years

Frequency: Annual

Country of Study: Any country

Application Procedure: Interested applicants must apply online at the SMRI website. Detailed instructions for application are available in printable format (PDF).

Closing Date: October 1st

Funding: Foundation, individuals 
Additional Information: Please check the master list of Stanley Medical Research Institute awarded trials on the website prior to completing the application. If we are supporting trials with the compound you propose, we are unlikely to support an additional trial until results are available.

\section{STANLEY SMITH (UK) HORTICULTURAL TRUST}

c/o Cambridge University Botanic Garden. Cory Lodge, 1 Brookside, Cambridge, CB2 1JE, England

Tel: (44) 1223336299

Fax: (44) 1223336278

Email: jc240@cam.ac.uk

Contact: Dr James Cullen, Director

The Stanley Smith (UK) Horticultural Trust supports projects that contribute to the development of the art and science of horticulture, i.e. garden conservation and restoration, education and training, research, publications and travel.

\section{Stanley Smith (UK) Horticultural Trust Awards}

Subjects: Horticulture. The Trust supports individual projects in all aspects (including training) of amenity horticulture and some aspects of commercial horticulture.

Eligibility: Open to institutions and individuals. All projects are judged entirely on merit and there are no eligibility requirements, but grants are not awarded for students to take academic or diploma courses of any kind.

Level of Study: Unrestricted

Type: Varies

Value: Varies

Length of Study: Dependent on the nature of the project

Country of Study: Any country

No. of awards offered: Varies

Application Procedure: Applicants must apply to the Trust. Trustees allocate awards in Spring and Autumn.

Closing Date: February 15th and August 15th (check with website) Funding: Private

Contributor: Donations

No. of awards given last year: 30

No. of applicants last year: 200

For further information contact:

Email: tdaniel@calacademy.org

Website: www.adminitrustllc.com/stanley-smith-horticultural-trust/

\section{STATE LIBRARY OF NEW SOUTH WALES}

\author{
Macquarie Street, Sydney, NSW, 2000, Australia \\ Tel: (61) 0292731414 \\ Fax: (61) 0292731255 \\ Email: library@sl.nsw.gov.au \\ Website: www.sl.nsw.gov.au \\ Contact: Mitchell Librarian
}

The State Library of New South Wales offers a number of prestigious \& competitive fellowships to support the study, writing \& teaching of Australian history \& culture.

\section{Ashurst Business Literature Prize}

Subjects: Australian corporate and commercial literature, histories, accounts and analyses of corporate affairs as well as biographies of business men and women.

Purpose: To encourage the highest standards of commentary in the fields of business and finance.

Eligibility: The author must be a living Australian citizen or hold permanent resident status. The work must have primary reference to business or financial affairs, business or financial institutions or people directly associated with business and financial affairs, be written in the English language, published in book form and consist of a minimum of 50,000 words.

Level of Study: Professional development

Type: Prize

Length of Study: Australian $\$ 30,000$
Frequency: Annual

Study Establishment: State Library of New South Wales

Country of Study: Australia

Application Procedure: All nominations must be made on the appropriate form, be submitted with five copies of the nominated work and be accompanied by an entry fee of Australian $\$ 66$ per title to be eligible for consideration. A separate form must be completed for each nomination. See State Library of NSW website www.sl.nsw.gov.au/awards/

Closing Date: December 5th (check with website)

Funding: Private

For further information contact:

Education and Client Liaison Branch, State Library of New South Wales, Australia

Email: smartin@sl.nsw.gov.au

Contact: Stephen Martin, Senior Project Officer

\section{H Currey Memorial Fellowship}

Subjects: Australian history.

Purpose: To promote the writing of Australian history from original sources of information, preferably making use of the collection of the State Library of New South Wales.

Eligibility: Applicants may be residents or non-residents of Australia. Preference will normally be given to applications that support research on a topic or project that is not being pursued as part of a higher degree programme.

Level of Study: Professional development

Type: Fellowship

Value: Australian $\$ 20,000$

Length of Study: 1 year

Frequency: Annual

Study Establishment: The State Library of New South Wales

Country of Study: Australia

Application Procedure: Applications should be made on forms available from the State Library or the website.

Closing Date: November 3rd

Additional Information: Please see the website for further details www.sl.nsw.gov.au/about/awards/currey.html.

\section{C.H. Currey Memorial Fellowships}

Purpose: For the writing of Australian history from original sources, preferably making use of the State Library's resources.

Type: Fellowship

Value: $\$ 20,000$

Length of Study: 12 months

Frequency: Annual

Study Establishment: The State Library of New South Wales

Country of Study: Australia

Application Procedure: Applications for the C.H. Currey Memorial Fellowship should be made on forms available from the State Library or on the website www.sl.nsw.gov.au/about/awards/currey.html.

Closing Date: September 19th

Funding: Private

Additional Information: Please see the website for further details www.sl.nsw.gov.au/about/awards/currey.html.

\section{Coral Thomas}

Purpose: Encourages deep and focused research into Australian culture, history and society, drawing on Australian and International Research Collections. It will also promote discussion on Australian history and culture through research which informs and engages contemporary discourse.

Level of Study: Unrestricted

Value: $\$ 75,000$

Frequency: Every 2 years

Closing Date: Check website

\section{David Scott Mitchell Memorial Fellowship}

Purpose: To encourage and support the use of the Mitchell Library's collections for the study and research of Australian history in writing and publication amongst scholars, researches and the wider community, including internationally.

Eligibility: Applicants may be residents or non-residents of Australia.

Type: Research fellowship

Value: $\$ 12,000$ 
Length of Study: 1 year

Frequency: Annual

Study Establishment: State Library of New South Wales

Country of Study: Australia

No. of awards offered: 1

Application Procedure: Applicants must complete an application

form, available on request.

Closing Date: May 30th

Funding: Trusts

Additional Information: Please see the website for further details www.sl.nsw.gov.au/about/awards.

\section{Dobbie Literary Award}

Subjects: Writing.

Purpose: To recognize a first published work from an Australian female writer.

Eligibility: Open to a first published work of fiction or nonfiction classifiable as 'Life Writing' by a woman author.

Value: Australian $\$ 5,000$

Frequency: Annual

Study Establishment: The State Library of New South Wales

Country of Study: Australia

Application Procedure: Applicants must complete an application form, available on request.

Funding: Private

For further information contact:

Tel: 1800501227

Email: philanthropy@perpetual.com.au

Website: www.sl.nsw.gov.au/about/awards/dobbie.html

\section{Jean Arnot Memorial Fellowship}

Subjects: Librarianship.

Purpose: To reward an outstanding original paper of no more than 5,000 words on any aspect of librarianship by a female librarian or a female student of librarianship.

Eligibility: The author must be a professional librarian or a student at an Australian school of librarianship. The submitted paper must be an outstanding original paper on any aspect of librarianship.

Level of Study: Professional development

Type: Fellowship

Value: Australian $\$ 1,000$

Length of Study: 1 year

Frequency: Annual

Study Establishment: State Library of New South Wales

Country of Study: Australia

No. of awards offered: 1

Application Procedure: Applicants must complete an application

form, available on request.

Closing Date: Check website

Funding: Private

Contributor: National Council of Women of New South Wales Incorporated and the Australian Federation of Business and Professional Women's Association Inc.

\section{Kathleen Mitchell Award}

Subjects: Writing, literature.

Purpose: To reward a novel by an Australian author.

Eligibility: Applicants must be aged 29 years or less at the time of your book's first publication and be a resident of Australia for the 12 months preceding the close of entries date and be either Australian or British born or a naturalized Australian.

Value: Australian $\$ 15,000$

Frequency: Every 2 years

Study Establishment: The State Library of New South Wales

Country of Study: Australia

Application Procedure: Applicants must complete an application

form, available on request.

Closing Date: Check with website

Funding: Private

Additional Information: Please see the website for further details http://thetrustcompany.com.au/wp-content/uploads/2013/02/

KathleenMitchellLiteraryAward1.pdf.
Kibble Literary Awards

Subjects: Writing.

Purpose: To recognize the work of an established Australian female writer.

Eligibility: Open to women writers of a published book of fiction or nonfiction classifiable as 'Life Writing'.

Value: Australian $\$ 30,000$

Frequency: Annual

Study Establishment: The State Library of New South Wales

Country of Study: Australia

Application Procedure: Applicants must complete an application

form, available on request.

Closing Date: Check with website

Funding: Private

For further information contact:

Tel: 1800501227

Email: philanthropy@perpetual.com.au

Website: www.sl.nsw.gov.au/about/awards/kibble.html

\section{Miles Franklin Literary Award}

Subjects: Australian literature.

Purpose: To promote excellence in Australian literature.

Eligibility: Novel must be of the highest literary merit and must present Australian life in any of its phases. Novels submitted must have been published in the year of entry of the award.

Level of Study: Professional development

Type: Award

Value: Australian $\$ 60,000$

Frequency: Annual

Application Procedure: Application forms can be downloaded from the website, see also State library of NSW website www.sl.nsw.gov. au/awards/

Closing Date: December 10th (check with website)

Funding: Individuals

For further information contact:

Cauz Group, Australia

Tel: (61) 0293321559

Fax: (61) 0293321298

Email: trustawards@cauzgroup.com.au

Website: www.sl.nsw.gov.au/about/awards/index.html

Contact: Petrea Salter

\section{Nancy Keesing Fellowship}

Subjects: Australian life and culture.

Purpose: For research into any aspect of Australian life and culture using the resources of the State Library of NSW.

Eligibility: Applicants may be either residents or non-residents of

Australia. Preference will normally be given to applications that support research on a topic or project that is not being pursued as part of higher degree programme.

Level of Study: Professional development

Type: Fellowship

Value: Australian $\$ 12,000$

Length of Study: 1 year

Frequency: Annual

Study Establishment: State Library of New South Wales

Country of Study: Australia

Application Procedure: Applications must be made on forms

available from the State Library or the website www.sl.nsw.gov.au/ awards/.

Closing Date: November 3rd (check with website)

Funding: Private

Additional Information: Please see the website for further details www.sl.nsw.gov.au/about/awards/index.html.

\section{National Biography Award}

Subjects: Writing.

Purpose: To encourage the highest standards of writing in the fields of biography and autobiography and to promote public interest in biography and autobiography.

Eligibility: Books eligible for nomination must have been first published between October 1st and September 30th, and be of a minimum length of 40,000 words. The subject of the work is to be an 
Australian or have made a significant contribution to Australia. Other subjects may be considered if the author is an Australian citizen or permanent resident and the work provides a particularly Australian perspective of the subject.

Level of Study: Professional development

Type: Award

Value: $\$ 25,000$ in prize money for a published work of biographical or autobiographical writing. Each of the shortlisted authors receive $\$ 1,000$ Frequency: Annual

Study Establishment: The State Library of New South Wales Country of Study: Australia

Application Procedure: See state library of NSW website.

Closing Date: February 20th

Funding: Individuals, private

Contributor: Geoffrey Cains

Additional Information: Please see the website for further details www.sl.nsw.gov.au/about/awards/national_biography/index.html.

\section{STATE SECRETARIAT FOR EDUCATION, RESEARCH AND INNOVATION SERI}

Einsteinstrasse 2, 3005, Bern, Switzerland Email: sgs@sbfi.admin.ch

Website: www.sbfi.admin.ch

\section{Swiss Government Excellence Scholarships for Foreign \\ Scholars and Artists}

Subjects: Applied sciences, music, and fine arts.

Purpose: The Swiss government, through the Federal Commission for Scholarships for Foreign Students (FCS), awards various postgraduate scholarships to foreign scholars and researchers.

Eligibility: These scholarships provide graduates from all fields with the opportunity to pursue doctoral or postdoctoral research in Switzerland at one of the public funded universities or recognised institutions.

Level of Study: Postdoctorate, Doctorate

Type: Scholarship

Frequency: Annual

Closing Date: The deadline for applications varies from one country to another

Additional Information: Please check www.sbfi.admin.ch/ scholarships_eng for detailed information.

\section{STATISTICAL SOCIETY OF CANADA}

210 - 1725 St. Laurent Blvd., Ottawa, Ontario, K1G 3V4, Canada Tel: (1) 6137332662

Fax: (1) 6137331386

Email: info@ssc.ca

Website: www.ssc.ca

Contact: Sudhir Paul, Chair, Pierre Robillard Award

The Statistical Society of Canada provides a forum for discussion and interaction among individuals involved in all aspects of the statistical sciences. It publishes a newsletter, Liaison as well as a scientific journal, The Canadian Journal of Statistics. The Society also organizes annual scientific meetings and short courses on professional development.

\section{Pierre Robillard Award}

Subjects: Statistics.

Purpose: To recognize the best PhD thesis defended at a Canadian university and written in a field covered by the Canadian Journal of Statistics.

Eligibility: Open to all postgraduates who have made a potential impact on the statistical sciences.

Level of Study: Doctorate

Type: Award

Value: A certificate, a monetary prize of Canadian $\$ 1,000$ and 1 year's membership of the Society

Frequency: Annual

Country of Study: Canada

No. of awards offered: 1
Application Procedure: Applicants must submit four copies of the thesis together with a covering letter from the thesis supervisor.

Closing Date: January 31st

No. of awards given last year: 1

No. of applicants last year: 8

Additional Information: The committee may decide that none of the submitted theses merits the award.

For further information contact:

Department of Mathematical and Statistical Sciences, University of Alberta, 632 Cab, Edmonton, AB, T6G 2G1, Canada

Tel: (1) 7804924230

Fax: (1) 7804926826

Email: kc.carriere@ualberta.ca

Contact: Dr Carrière Keumhee, Professor

\section{STELLENBOSCH UNIVERSITY}

Private Bay XI, Matieland, 7602, South Africa

Tel: (27) 218089111

Fax: (27) 218083799

Email: info@sun.ac.za

Website: www.sun.ac.za

The raison Dé of the chemistry of Stellenbosch is to create and sustain, in commitment to the academic ideal of excellent scholarly and scientific practice, an environment within which knowledge can be discovered, shared and applied for the benefit of the community.

\section{Harry Crossley Master's and Doctoral Bursary}

Subjects: All subject, with the exception of theology and political science.

Purpose: To reward academically above-average students.

Eligibility: To full-time students registered at Stellenbosch University in any postgraduate degree programme except theology and political science.

Level of Study: Doctorate, Postgraduate

Type: Bursary

Value: Rand 75,000 (Honours), ZAR 80,000 (Master's), ZAR 90,000 (Doctoral)

Length of Study: 1 year

Frequency: Annual

Study Establishment: Stellenbosch University

Country of Study: South Africa

Closing Date: October 15th

Funding: Foundation

Contributor: Harry Crossley Foundation

No. of awards given last year: 30

No. of applicants last year: 500

Additional Information: Please see the website further details.

For further information contact:

The Office for Postgraduate Student Funding, Postgraduate and International Office, Wilcocks Building, Room A 3015

Tel: 0218084208

Fax: 0218083799

Email: postgradfunding@sun.ac.za

\section{Stellenbosch Merit Bursary Award}

Subjects: Any subject.

Purpose: To reward academically above-average students.

Eligibility: Available to full-time students registered at Stellenbosch

University in any postgraduate degree programme.

Level of Study: Postgraduate

Type: Bursary

Value: Rand 4,100-34,700

Length of Study: Up to 2 years

Frequency: Annual

Study Establishment: Stellenbosch University

Country of Study: South Africa

Application Procedure: Students must submit an application and a certified copy of a complete, official academic record.

Closing Date: December 6th

Contributor: Stellenbosch University 
No. of awards given last year: 340

No. of applicants last year: Approx. 700

For further information contact:

Office for postgraduate student funding, Postgraduate and International Office, Wilcocks Building, Room 3015

Tel: 0218084208

Fax: 0218083799

Email: postgradfunding@sun.ac.za

\section{STOUT RESEARCH CENTRE, VICTORIA UNIVERSITY OF WELLINGTON}

\author{
PO Box 600, Wellington, 6140, New Zealand \\ Tel: (64) 44635305 \\ Fax: (64) 44635439 \\ Email: stout-centre@vuw.ac.nz \\ Website: www.vuw.ac.nz/stout-centre \\ Contact: Dr Lydia Wevers, Director
}

The Stout Research Center was established in 1984 to encourage scholarly inquiry into New Zealand society, history and culture, and to provide a focus for the collegial atmosphere and exchange of ideas that enrich the quality of research.

\section{J D Stout Fellowship}

Subjects: New Zealand society, history and culture.

Purpose: To encourage research.

Eligibility: Open to distinguished scholars from New Zealand and abroad.

Level of Study: Postdoctorate

Type: Fellowship

Value: Within the Research Fellow scale depending upon the qualifications and experience of the applicant

Length of Study: 1 year

Frequency: Annual

Study Establishment: The Stout Research Centre

Country of Study: New Zealand

No. of awards offered: 1

Application Procedure: Applicants must write for details.

Closing Date: September 1st

Funding: Trusts

Contributor: Stout Trust

Additional Information: Please see the website for further details

www.victoria.ac.nz/stout-centre/research-opportunities/jd-stout-info.

\section{STROKE ASSOCIATION}

\author{
Stroke House, 240 City Road, London, EC1V 2PR, England \\ Tel: (44) 02075661543 \\ Email: research@stroke.org.uk \\ Website: www.stroke.org.uk \\ Contact: Rachael Sherrington, Research Awards Officer
}

The Stroke Association funds research into stroke prevention, treatment, rehabilitation, and long term care. It also helps stroke patients and their families directly through community services. It campaigns, educates and informs to increase knowledge of stroke at all levels of society and it acts as a voice for everyone affected by stroke.

\section{Joint Stroke Association/British Heart Foundation Clinical Study in Stroke}

Subjects: Applications must be directly related to stroke illness, and must have a vascular focus.

Purpose: We are delighted to invite applications for a Clinical Study in the field of stroke, which will be awarded jointly between the Stroke Association and the British Heart Foundation.

Eligibility: Awards are tenable only at Universities, NHS Trusts, Statutory Social Care Organizations or other Research Institutions within the United Kingdom of Great Britain and Northern Ireland. Type: Grant

Value: $£ 1,500,000$

Length of Study: Up to 5 years

Frequency: Annual

Study Establishment: Suitable U.K. university or NHS Trust
No. of awards offered: 1

Application Procedure: If an application was unsuccessful in a previous round, the same application cannot be resubmitted. Please see the guidance document and Terms and Conditions on the website for full details of the application process.

Closing Date: December (Outline application)

Funding: Private, trusts

Contributor: Donations

No. of applicants last year: 11

Additional Information: Please check www.stroke.org.uk/research/ looking-funding/joint-stroke-association-british-heart-foundationclinical-study-stroke for more information.

\section{Lectureships Programme}

Subjects: Over the next few years we will support 15 Stroke Association Lecturer, Senior Lecturer and Reader positions. Purpose: As part of a new research strategy we are committing ourselves to building the next generation of research leaders. These lectureship positions will play a critical role in building a vibrant community of clinical and non-clinical stroke researchers across the UK.

Eligibility: There are 7 options for the fellowship awards that applicants can apply for. Please check information for all available options at www.stroke.org.uk/sites/default/files/files/Lectureship Programme Briefing.pdf.

Type: Programme

Length of Study: 4-5 years

Frequency: Annual

Study Establishment: Suitable U.K. University

No. of awards offered: Variable

Application Procedure: Please check complete information at www.stroke.org.uk/research/lectureship-programme.

Closing Date: November

Funding: Private, trusts

Contributor: Donations

Additional Information: For more information please see: www.stroke.org.uk/research/looking-funding/lectureships

\section{The Stroke Association Postdoctoral Fellowship}

Subjects: Stroke research.

Purpose: To support nurses or allied health professionals to embark on an independent career in academic stroke research. The Stroke Association's research strategy aims to increase the U.K. funding base and capacity for stroke research across the full stroke care pathway. These Fellowships are aimed at the stroke research leaders of the future.

Eligibility: Awarded to a department in the UK that can provide an educational programme and the expert supervision required to enable a to gain the appropriate research experience required for a career in stroke. Open to postdoctoral candidates from a nursing or allied health professional background. Medical professionals are not eligible to apply. Level of Study: Postdoctorate, Professional development

Type: Fellowship

Value: $£ 175,000$

Length of Study: 3-5 years

Frequency: Annual

Study Establishment: Suitable universities and NHS trusts

Country of Study: United Kingdom

No. of awards offered: 2

Application Procedure: Application forms are available from the website.

Closing Date: November

Funding: Private, trusts

No. of awards given last year: 2

No. of applicants last year: 8

Additional Information: For more information please visit: www. stroke.org.uk/research/looking-funding/postdoctoral-fellowships.

\section{The Stroke Association Postgraduate Fellowship}

Subjects: Stroke research.

Purpose: For outstanding nurse and allied health professional graduates intending to study for a PhD. The Stroke Association's research strategy aims to increase the U.K. funding base and capacity for stroke research across the full stroke care pathway. These Fellowships are aimed at the stroke research leaders of the future. 
Eligibility: Open to nurses and allied health professionals, but consideration will be given to other health professionals. They will be awarded to departments that can demonstrate a track record and current participation in stroke research.

Level of Study: Professional development, Postgraduate Type: Fellowship

Value: UK£35,000 per year for 2 years, with a discretionary extension of $£ 35,000$ for the 3 rd year

Length of Study: $3-5$ years

Frequency: Annual

Study Establishment: Suitable universities and hospitals and NHS trusts

Country of Study: United Kingdom

No. of awards offered: 2

Application Procedure: Application forms are available from the website.

Closing Date: January 13th

Funding: Trusts, private

Contributor: Donations

No. of awards given last year: 2

No. of applicants last year: 12

Additional Information: For more information, please see:

www.stroke.org.uk/research/looking-funding/postgraduate-

fellowships.

\section{The Stroke Association Research Project Grants}

Subjects: Any research on stroke across the entire stroke pathway. Prevention, acute treatment and care, rehabilitation and long term treatment and care.

Purpose: To advance research into stroke.

Eligibility: Open to researchers in the UK in the relevant fields.

Applications are judged by peer review on their merit without

limitations of age. Applicants can be from any country but must be based in the UK.

Level of Study: Research

Type: Project grant

Value: Up to $£ 210,000$

Length of Study: 3-5 years

Frequency: Annual

Study Establishment: A suitable university or hospital in the UK Country of Study: United Kingdom

No. of awards offered: Approx. 5 per year

Application Procedure: Application forms are available from the website.

Closing Date: February

Funding: Private, trusts

Contributor: Donations

No. of awards given last year: 3

No. of applicants last year: 20

Additional Information: Please visit www.stroke.org.uk/research/ looking-funding/project-grants.

For further information contact:

Email: research@stroke.org.uk

\section{Stroke Association/MRC Joint Clinical Research Training Fellowships}

Purpose: To provide an opportunity for clinically trained individuals to undertake training in stroke research. The scheme is designed to accommodate the dual clinical-research training career path by allowing fellows to spend up to 20 per cent of their time on NHS sessions. Eligibility: There are many fellowships in this category so please refer to the website to find exact information about a particular fellowship.

Level of Study: Postgraduate

Type: Fellowship

Length of Study: 3 years

Frequency: 2 times per year

No. of awards offered: 1

Application Procedure: Fellows are required to register for a research degree, normally a $\mathrm{PhD}$, based on research undertaken during the Fellowship.

Additional Information: Please see the MRC website for detailed information - www.mrc.ac.uk/skills-careers/fellowships/clinicalfellowships/jointly-funded-clinical-research-training-fellowship.
SWANSEA UNIVERSITY

Singleton Park, Swansea, Wales, SA2 8PP, United Kingdom Tel: (44) 01792205678

Fax: (44) 01792295157

Email: sro@swansea.ac.uk, M.W.Skippen@swansea.ac.uk Website: www.swan.ac.uk

Contact: Dr Mark Skippen, Senior Postgraduate Recruitment Officer

Swansea University is a UK top 30 institution for research excellence (REF2014) that has been providing the highest quality postgraduate teaching since 1920. Our campuses are situated on the stunning sandy beach of Swansea Bay. We have taught and research postgraduate funding for UK, EU and international students: www.swansea.ac.uk/postgraduate/scholarships

\section{College of Engineering: EngD Scholarship}

Subjects: Computational modelling, functional coatings, materials and manufacturing.

Purpose: To prepare students for research and industry leadership careers.

Eligibility: Open to Masters or Bachelor students with a First Class Honours or a good 2.1 degree in a suitable engineering, mathematical or scientific discipline. Students must have settled status in the UK and been ordinarily resident in the UK for 3 years prior to the start of the grant.

Level of Study: Doctorate

Type: Studentship

Value: Full studentship of up to $£ 20,000$ per year, plus tuition fees

Length of Study: 4 years

Frequency: Annual

Study Establishment: Swansea University

Country of Study: United Kingdom

No. of awards offered: Approx. 10

Application Procedure: Check the website www.swansea.ac.uk/ engineering for further details.

Closing Date: Please contact organisation for details

Contributor: Swansea University and Industrial Partners

Additional Information: Please contact College of Engineering at engineering@swansea.ac.uk.

The Eira Francis Davies Scholarship

Subjects: Health and medical related subjects.

Eligibility: Open to Non-EU, female student ordinarily resident in a developing country.

Level of Study: Postgraduate, Undergraduate

Type: Scholarship

Value: Full international tuition fee

Frequency: Annual

Study Establishment: Swansea University

Country of Study: United Kingdom

No. of awards offered: 1

Application Procedure: Complete application form available online at www.swansea.ac.uk/international.

Closing Date: June

Contributor: Eira Francis Davies

No. of awards given last year: 1

\section{International Excellence Scholarships}

Subjects: All subjects.

Eligibility: Awards are available to postgraduate applicants from outside the EU. Other eligibility criteria may apply. Please contact us for details.

Level of Study: Postgraduate

Type: Scholarship

Value: Approx. $£ 4,000$

Length of Study: 1 year (Masters)

Frequency: Annual

Study Establishment: Swansea University

Country of Study: United Kingdom

No. of awards offered: Approx. 40

Application Procedure: Complete application form, available online at website.

Closing Date: June 2nd

Additional Information: Please contact at international@swansea. ac.uk for further information. South America and India are also eligible 
countries. Please check at www.swan.ac.uk/international/students/ fees-and-funding/pg_scholarships/for further information.

\section{PhD Fees-only Bursaries}

Subjects: Normally available in all subject areas.

Eligibility: Open to good Master's graduates from the UK/EU who will be commencing PhD studies at Swansea University.

Type: Scholarship

Value: Covers UK/EU tuition fees

Length of Study: 3 years

Frequency: Annual

Study Establishment: Swansea University

Country of Study: United Kingdom

No. of awards offered: Approx. 10

Application Procedure: Please contact us for an application form.

No. of awards given last year: 10

For further information contact:

Postgraduate Admissions Office, Swansea University, Wales Email: admissions-enquiries@swansea.ac.uk

Website: www.swansea.ac.uk/postgraduate

\section{Swansea University College of Law Scholarships}

Subjects: Graduate diploma in law (GDL) and legal practice course (LPC).

Eligibility: Applicants to the GDL must have an undergraduate degree awarded by a recognised UK or Republic of Ireland institution. Applicants to the LPC must have an honours degree in law with a classification of 2:2 or higher, or a graduate diploma in law. Tuition fee discounts are awarded according to previous institution, country of residence, employment status and stage of study.

Type: Scholarship

Value: Tuition fee discounts of between approx. $£ 860-7,100$

Frequency: Annual

Study Establishment: Swansea University

Country of Study: United Kingdom

Application Procedure: Automatically applied on enrolment to those who meet the eligibility criteria.

Additional Information: Full details can be found online at www. swansea.ac.uk/postgraduate/scholarships.

\section{Swansea University College of Science International Scholarships}

Subjects: Scholarships are provided in the field of Environmental Biology, Advanced Computer Science, Software Technology, Human Computer-Interaction, Visual Computing, Safe \& Secure Systems, Computer Science, Environmental Dynamics and Climate Change, Geographic Information and Climate Change, Mathematics and Computing for Finance, Aquatic Ecology \& Conservation, Sustainable Aquaculture \& Fisheries, Visual Computing, Logic and Computation, Computing and Future Interaction Technologies, Stochastic Processes - Theory and Application(MRes) A range of MSc by Research degrees in Biosciences, A range of MSc by Research degrees in Computer Science, A range of MSc by Research degrees in Geography and MSc by Research in Mathematics.

Eligibility: Scholarships are available only to new postgraduate applicants who are non-UK/EU categorized students from the regions specified in the key information and funding sections. Scholarships will be used to offset tuition fees. Applicants should hold a minimum of a 2.1 degree (or equivalent) and should have already applied formally to the University for a place on one of the College's postgraduate programmes. Information regarding the application procedure can be found on the Admissions Office website. Please note that applicants progressing from ICWS are not eligible to apply for a College of Science International Scholarship. Applicants must enroll on a course in the College for the first time in September.

Level of Study: Postgraduate

Type: Scholarship

Value: Each scholarship is to be offset against international tuition fees. The value of individual scholarships depends on which region the applicants are from and is as follows: Africa Regional Scholarship - £2,000; East Asia Regional Scholarship - £2,000; South Asia Regional Scholarship - £2,000; Other Regions Scholarship - £2,000; South America Scholarship - £1,000 Country of Study: United Kingdom
Application Procedure: Application form available online: www.swansea.ac.uk/postgraduate/scholarships

Closing Date: July

Contributor: College of Science, Swansea University, UK

Additional Information: The students of Africa, East Asia, South

Asia, North America, South America and Other Regions can apply for the scholarships. Applicants will be informed of the outcome of their application by the end of June.

\section{Swansea University Masters Scholarships}

Subjects: Available in all academic subjects.

Eligibility: Open to students from the UK/Eu who will be starting an eligible master's course at Swansea University for the first time in September.

Level of Study: Postgraduate

Type: Scholarship

Value: Approx. $£ 3,000$ towards tuition fees

Length of Study: 1 year full time or 2-3 years part-time

Frequency: Annual

Study Establishment: Swansea University

Country of Study: United Kingdom

No. of awards offered: 100

Application Procedure: Eligible students are sent an application form when offered a place on a course.

Closing Date: July

No. of awards given last year: 100

For further information contact:

Postgraduate Admissions Office, Swansea University, Wales Email: postgraduate.admissions@swansea.ac.uk

\section{Swansea University PhD Scholarships}

Subjects: Normally available in all subject areas. Please check our website www.swansea.ac.uk/postgraduate for details.

Eligibility: Open to good Masters graduates from the UK/EU who will be commencing PhD studies at Swansea University.

Level of Study: Doctorate, Postgraduate

Type: Scholarship

Value: Annual stipend at Rcuk level (approx. £14,000)

Length of Study: 3 years

Frequency: Annual

Study Establishment: Swansea University

Country of Study: United Kingdom

No. of awards offered: Approx. 18

Application Procedure: Please see individual scholarship listings on our website: www.swansea.ac.uk/postgraduate/scholarships/research Closing Date: Throughout year

No. of awards given last year: 15

For further information contact:

Postgraduate Admissions Office, Swansea University, Wales

Email: postgraduate.admissions@swansea.ac.uk

\section{SWEDISH INFORMATION SERVICE}

445 Park Avenue, 21st floor, New York, NY, 10022, United States of America

Tel: (1) 2128883000

Fax: (1) 2128883125

Email: generalkonsulat.new-york@foreign.ministry.se Website: www.swedennewyork.com

Contact: Consulate General of Sweden

The Section for culture and Public Affairs of the Consulate General of Sweden in New York works to promote awareness in the US of Swedish cultural achievement and advancement in scientific research and development, and contributes to the formation of public opinion and policy in an international context.

\section{Bicentennial Swedish-American Exchange Fund}

Subjects: Politics, public administration, working life, human environment, mass media, business and industry, education or culture. Purpose: To provide an opportunity for those in a position to influence public opinion and contribute to the development of their society to make an intensive research trip to Sweden. 
Eligibility: Applicants should be citizens or permanent residents of the US. People who have made recurrent visits to or resided in Sweden will only be considered in exceptional circumstances. The grant may not be used to finance participation in conferences or regular ongoing vocational or academic courses. If co-applicants on the same project are selected, the grant will be divided between them. The grant may be used in conjunction with scholarships from other sources.

Level of Study: Research

Type: Travel grant

Value: The Bicentennial Fund will award grants of up to SEK 30,000 each for proposed study visits to Sweden for two to four weeks. The Bicentennial grant may be used in conjunction with scholarships from other sources

Length of Study: 2-4 weeks intensive research

Frequency: Annual

Country of Study: Sweden

No. of awards offered: 2

Application Procedure: Application forms are available from the website or can be requested directly from the Swedish institute. Two letters of recommendation are also required.

Closing Date: Applications must reach the Swedish Institute by November 15th for a study visit in Sweden for the period (March 1st-December 31st)

Funding: Government

Contributor: The Swedish Institute in Stockholm, Sweden

No. of awards given last year: 5

No. of applicants last year: 40

Additional Information: The project must be completed within 1 year of receipt of the grant. A report must be submitted to the Swedish institute 1 month after the research trip is completed. Award recipients are announced during the month of May.

For further information contact:

Website: www.studyinsweden.se

\section{THE SWEDISH INSTITUTE}

\author{
Slottsbacken 10, S-103 91 Stockholm, Box 7434, Sweden \\ Tel: (46) (0)8 4537800 \\ Email: si(a)si.se \\ Contact: The Swedish Institute
}

SISS is the Swedish government's international awards scheme aimed at developing global leaders. It is funded by the Ministry for Foreign Affairs of Sweden and administered by the Swedish Institute (SI). The programme offers a unique opportunity for future leaders to develop professionally and academically, to experience Swedish society and culture, and to build a long-lasting relationship with Sweden and with each other.

\section{SI Scholarships for the Western Balkans Programme}

Subjects: Social sciences.

Purpose: The SI Scholarships for the Western Balkans Programme aims at supporting advanced level studies and research within the field of social sciences in order to forge closer links between the Western Balkans and the European Union, and to contribute to strengthened democracy in the region.

Eligibility: The scholarships are intended for PhD students and postdoctoral researchers from Albania, Bosnia-Herzegovina, Kosovo, Macedonia (FYROM), Montenegro and Serbia conducting part of their studies/research in Sweden within the field of social sciences.

Level of Study: Doctorate, Postdoctorate

Type: Scholarship

Value: SEK 15,000 per month for PhD students, and SEK 18,000 per month for postdoctoral researchers and senior scientists

Length of Study: 1 year

Frequency: Annual

Country of Study: Sweden

No. of awards offered: 4

Application Procedure: Online application portal.

Closing Date: November 1st to January 10th

Contributor: Ministry for Foreign Affairs of Sweden and administered by the Swedish Institute (SI)

Additional Information: Please contact sischolarships(a)si.se if you have any questions.
The Swedish Institute Study Scholarships (SISS)

Purpose: SISS is the Swedish government's international awards scheme aimed at developing global leaders.

Eligibility: Applicants must be from an eligible country and have at least 3,000 hours of experience from full-time/part-time employment, voluntary work, paid/unpaid internship, and/or position of trust. Applicants must display academic qualifications and leadership experience. In addition, applicants should show an ambition to make a difference by working with issues which contribute to a just and sustainable development in their country, in a long term perspective. The travel grant is a one-time payment of SEK 15,000.

Level of Study: Foundation programme

Type: Scholarship

Value: The scholarship covers both tuition fees (paid directly to the Swedish university/university college by the Swedish Institute) and living expenses to the amount of SEK 9,000 per month. There are no additional grants for family members

Length of Study: The scholarship is intended for full-time master's level studies of one or two years, and is only awarded for programmes starting in the autumn semester. The scholarship covers the whole duration of the master's programme

No. of awards offered: 335

Closing Date: December 1st and February 10th

Funding: Government

Contributor: Ministry for Foreign Affairs of Sweden

\section{The Swedish Institute Study Scholarships for South Africa}

Purpose: The programme offers a unique opportunity for future leaders to develop professionally and academically, to experience Swedish society and culture, and to build a long-lasting relationship with Sweden and with each other.

Type: Scholarship

Value: The scholarship covers both tuition fees (paid directly to the Swedish university/university college by the Swedish Institute) and living expenses to the amount of SEK 9,000 per month. The travel grant is a one-time payment of SEK 15,000

Length of Study: Whole duration of the master's programme Country of Study: Sweden

No. of awards offered: 10 scholarships for South African citizens Application Procedure: Online application.

Closing Date: December 1st to January 16th and February 10th Contributor: Ministry for Foreign Affairs of Sweden and administered by the Swedish Institute (SI)

\section{Swedish-Turkish Scholarship Programme for PhD studies and postdoctoral research \\ Subjects: Social sciences.}

Purpose: The Swedish-Turkish Scholarship Programme aims at supporting advanced level studies and research in order to forge closer links between Turkey and the European Union, and to contribute to strengthened democracy and a greater respect for human rights.

Eligibility: The scholarships are intended for $\mathrm{PhD}$ students and postdoctoral researchers from Turkey conducting part of their studies/ research in Sweden within the field of social sciences.

Level of Study: Doctorate, Postdoctorate

Type: Scholarship

Value: SEK 15,000 per month for PhD students, and SEK 18,000 per month for postdoctoral researchers and senior scientists

Length of Study: 1 year

Country of Study: Sweden

No. of awards offered: 4 to 5 scholarships

Closing Date: November 1st to January 10th

Contributor: Ministry for Foreign Affairs of Sweden and administered by the Swedish Institute (SI)

Additional Information: Please contact sischolarships@si.se if you have any questions.

\section{Visby Programme Scholarships}

Subjects: All fields of study.

Purpose: The aim of the Visby Programme is to support individual mobility, thereby contributing to increased contacts and collaborations between actors in Sweden and countries in the EU Eastern 
Partnership and Russia. The goal is to build an integrated, knowledgebased and research-intense region, centred on the Baltic Sea while also including EU Eastern Partnership countries and Russia. Eligibility: PhD student, applying for a part of his/her ongoing PhD studies to be carried out in Sweden (1 year maximum). Postdoctoral researcher, with priority given to holders of a $\mathrm{PhD}$ degree from 2012 or later (1 year maximum). Senior scientist - holders of a $\mathrm{PhD}$ degree obtained before 2012 (6 months maximum).

Level of Study: Doctorate, Postdoctorate

Type: Scholarship

Value: SEK 15,000 per month for PhD students, and SEK 18,000 per month for postdoctoral researchers and senior scientists. The scholarship cannot be prolonged or extended

No. of awards offered: 40

Application Procedure: Applications are evaluated by the Swedish Institute (SI) and an academic board. Online application form.

Closing Date: November 1st to January 10th

Additional Information: Please contact sischolarships(a)si.se if you have any questions.

\section{SWINBURNE UNIVERSITY OF TECHNOLOGY}

\author{
PO Box 218, Hawthorn, VIC, 3122, Australia \\ Tel: (61) 0392148000 \\ Fax: (61) 0392148637 \\ Email: webmaster@swin.edu.au \\ Website: www.swinburne.edu \\ Contact: MBA Admissions Officer
}

It provides career-orientated education and as a university with a commitment to research. The University maintains a strong technology base and important links with industry, complemented by a number of innovative specialist research centres which attract a great deal of international interest. A feature of many Swinburne undergraduate courses is the applied vocational emphasis and direct industry application through Industry Based Learning (IBL) programs. Swinburne was a pioneer of IBL program which places students directly in industry for vocational employment as an integral part of the course structure. Swinburne is committed to the transfer of lifelong learning skills. It is heavily involved in international initiatives and plays a significant part in the internationalization of Australia's tertiary education system.

\section{Australian Postgraduate Award (APA)}

Subjects: All subjects

Purpose: To support study towards a Higher Degree by Research Eligibility: Open to citizens of Australia, New Zealand citizens and Australian permanent residents.

Level of Study: Doctorate, Research

Type: Award

Value: A non-taxable indexed stipend of around $\$ 23,728$ per year and a tuition fee scholarship (total value around $\$ 49,000$ per year)

Length of Study: 3 years

Application Procedure: Check website for further details.

Closing Date: October 31st

Additional Information: Please see the website for further details.

\section{Chancellor's Research Scholarship}

\section{Subjects: All subjects.}

Purpose: To award students of exceptional research potential to undertake a higher degree by research (HDR).

Eligibility: Open to a local or an international student undertaking a higher degree by research (HDR) with Bachelor Degree with First

Class Honours. For further details, please check the website.

Level of Study: Doctorate

Type: Research scholarship

Value: An annual stipend of $\$ 30,000$, an Establishment Grant of up to $\$ 3,000$ and up to $\$ 5,000$ for a 6 -month overseas placement Length of Study: 3 years

Frequency: Annual

Application Procedure: Check website for further details.

Additional Information: Please refer website for details: www. swinburne.edu.au/study/options/scholarships/215/chancellorsresearch-scholarship-/

\section{For further information contact:}

Building $60 \mathrm{Wm}$, Level 7, 60 William Street, Hawthorn campus

Tel: 92145547 or 92148744

Email: ehill@swin.edu.au, jamathews@swin.edu.au

\section{Swinburne University Postgraduate Research Award (SUPRA)}

Subjects: All subjects.

Eligibility: Open to citizens of all overseas countries except New Zealand who have completed at least 4 years (or equivalent) of tertiary education studies at a high level of achievement. Plus students must demonstrate English Language proficiency: IELTS.

Level of Study: Doctorate, Postgraduate

Type: Research scholarship

Value: A non-taxable indexed stipend of around $\$ 25,849$ per year and a tuition fee scholarship for up to three years

Length of Study: 3 years

Country of Study: Australia

Application Procedure: Complete an application for admission to research higher degree candidature and scholarship and mail/courier or scan your application forms and email them.

Closing Date: May (Mid-Year Round) and October (Main Round)

Contributor: Australian Department of Education, Science and

Training (DEST)

Additional Information: Please see the website for further details www.research.swinburne.edu.au/research-students/scholarships.

\section{Swinburne University Postgraduate Research Award} (SUPRA)

Subjects: All subjects.

Purpose: To assist with general living costs

Eligibility: Open to domestic or an international student undertaking a higher degree by research. Hold a bachelor's degree with first-class honours or equivalent. Please check the website for further details.

Level of Study: Doctorate, Research

Type: Research award

Value: Annual stipend $\$ 26,288$ (indexed) for three years (with possible 6 month extension). Tuition fees for up to four years and thesis allowance

Length of Study: 3 years (Research Doctorate)

Application Procedure: Please check website for further details. Closing Date: Check with website www.swinburne.edu.au/research/ funding-grants/scholarships

For further information contact:

Building 60Wm, Level 7, 60 William Street, Hawthorn campus Tel: 92145547 or 92148744

Email: ehill@swin.edu.au, jamathews@swin.edu.au

Website: www.research.swinburne.edu.au/research-students/ scholarships/supra.html

\section{Swinburne University Vice-Chancellor's International Scholarship (VCIS) in Australia}

Purpose: The Swinburne University Vice-Chancellor's International Scholarship (VCIS) is a new scholarship available only in the Mid-Yea Scholarship Round

Eligibility: To be eligible for a VCIS, a student: must be an international student; and must have completed a Bachelor's Degree with First Class Honours, or be regarded by the University as having an equivalent level of attainment in accordance with these guidelines and must be undertaking a Research Doctorate; and must be enroled as a full-time student; and be ineligible for study under the Commonwealth's Research Training Scheme (RTS) at the commencement of the HDR; and must not hold a research doctorate or equivalent research qualification; and must not previously have held a postgraduate research scholarship (some exceptions may apply, contact Swinburne Research for more information); and must not be receiving an equivalent award, scholarship (excluding an IPRS) or salary providing a benefit greater than 75 per cent of the VCIS stipend rate, to undertake the HDR. Income from sources unrelated to the course of study is permitted but must be within the confines of HDR policy section 7.9 'Employment Commitments'.

Type: Scholarship 
Value: The awards provide an annual stipend of $\$ 25,849$ and cover the cost of Overseas Health Cover (OSHC). The award also covers the cost of tuition

Frequency: Annual

Country of Study: Australia

Application Procedure: If you wish to be considered for a scholarship you must complete the scholarship portion of the candidature application form. Research degree candidature is considered all year round. Visit the application page (at www.research.swinburne.edu.au/ research-students/future/application/) for information on applying for a research degree.

Closing Date: May 29th

Additional Information: Please check at www.research.swinburne. edu.au/research-students/scholarships/ for detailed information.

\section{Vice Chancellor's Centenary Research Scholarship (VCRS)}

Subjects: All subjects.

Purpose: To assist with general living costs.

Eligibility: Open to domestic or an international student who have completed a Bachelor degree with First Class Honours and are of exceptional research potential undertaking a higher degree by research (HDR). For further details, please check the website. Level of Study: Research

Type: Research scholarship

Value: The value of the VCRS will be up to $\$ 35,000$ (tax-exempt) over a maximum period of up to 3.5 full-time years, payable at the rate of $\$ 5,000$ per year for the 1 st year and $\$ 12,000$ per year for the remaining 2.5 years

Length of Study: 3 years

Application Procedure: Check website for further details.

For further information contact:

Building 60Wm, Level 7, 60 William Street, Hawthorn campus Tel: 92145547 or 92148744

Email: ehill@swin.edu.au, jamathews@swin.edu.au

Website: www.research.swinburne.edu.au/research-students/ scholarships/vcrs.html

\section{SWISS FEDERAL INSTITUTE OF TECHNOLOGY ZÜRICH}

International Instituitional Affairs, Rämistrasse 101, Zurich, $\mathrm{CH}-8092$, Switzerland Tel: (41) 446321111 Fax: (41) 446321010

Email: international@sl.ethz.ch, hagstroem@sl.ethz.ch Website: www.ethz.ch

Contact: Anders Hagstrom

The Swiss Federal Institute of Technology Zurich is a science and technology university with an outstanding research record. Excellent research conditions, state-of-the-art infrastructure and an attractive urban environment add up to the ideal setting for creative personalities.

\section{Engineering for Development (E4D) Doctoral \\ Scholarships}

Subjects: Topics limited to those covered by the research groups of the ETH Zurich.

Purpose: Scholarships for doctoral students on research for the benefit of developing countries.

Eligibility: Open to Doctorate students with academic excellence and depending on the candidate's contribution to the field. Topics relevant to development; topic within scope of ETH Zurich; research aims to develop a product/method directly relevant for improving the lives of poor people in developing countries.

Level of Study: Doctorate

Type: Fellowship

Value: Swiss Franc 50,000 per year

Length of Study: 3 years

Frequency: Annual

Country of Study: Switzerland

No. of awards offered: 2
Application Procedure: Two-step procedure: (i) concept note, (ii) full proposal. All details under the website given below.

Closing Date: October 31st

Funding: Foundation

Contributor: Sawiris Foundation for social development

No. of awards given last year: 2

No. of applicants last year: 8

Additional Information: Please check online at www.global.ethz.ch for more information.

\section{ETH Zurich Excellence Scholarship and Opportunity Award}

Subjects: Architecture, engineering, (civil, mechanical, electrical, production, rural and surveying), computer science, materials science, chemistry, physics, mathematics, biology, environmental sciences, earth sciences, pharmacy, agriculture and forestry, international relations and political science.

Purpose: Full scholarships for tuition and cost of living for talented students of master's programs.

Eligibility: Open to graduates in one of the discipline represented at ETH Zurich with very good academic record.

Level of Study: Graduate, Master

Type: Scholarship

Value: Swiss Franc 11,000 per semester plus tuition waiver

Length of Study: 18-24 months

Frequency: Annual

Study Establishment: ETH Zurich

Country of Study: Switzerland

No. of awards offered: 50

Application Procedure: Applications must be made to the appropriate address. See www.ethz.ch for further information.

Closing Date: December 15th

Funding: Foundation

Contributor: ETH Zurich Foundation

No. of awards given last year: 50

No. of applicants last year: 540

For further information contact:

Website: www.ethz.ch

Contact: Anders Hagström, Director Global Education

\section{ETH Zurich Postdoctoral Fellowships}

Subjects: The ETH Zurich Postdoctoral Fellowship Program supports incoming fellowships for postdoctoral researchers at the ETH Zurich Applications have to be made jointly by the candidate and their host who must be an ETH Zurich Professor and who will act as a mentor to the fellow.

Purpose: The program is intended to foster high-potential, young researchers who have already demonstrated excellence in terms of internationally competitive achievements in the early stages of their professional careers.

Eligibility: Eligible are young postdoctoral scientists worldwide, who have been awarded their doctoral degree within 2 years of the relevant submission deadline. The applicants need to have at least one scientific publication in a peer-reviewed journal or have been awarded a prize for their PhD thesis. Exception: Postdoctoral scientists who have obtained a doctoral degree from the ETH Zurich or the University of Zurich cannot apply for this fellowship program. Also not eligible are postdoctoral scientists who performed their main activities (work, studies, etc.) at one of the two institutions for more than 6 months prior to the relevant submission deadline.

Level of Study: Postdoctorate

Type: Fellowship

Value: $\$ 220,000$ including full social security, and a lump sum of 20,000 for research and mobility costs for 2 years

Length of Study: 2 years

Study Establishment: ETH Zurich (Swiss Federal Institute of Technology)

Country of Study: Switzerland

No. of awards offered: 30

Application Procedure: Two-step procedure, with a proposal-based preselection and an interview-based evaluation of preselected candidates. Applications will be assessed against criteria addressing the candidate's aptitude, the quality of the proposed research and the 
synergy with the host lab. Successful applications must be convincing in all respects.

Closing Date: March 1st and September 1st

Funding: Government

Contributor: ETH Zurich and European Union (via COFUND, Marie Curie Actions for People)

No. of awards given last year: 30

No. of applicants last year: 340

Additional Information: Please use our online submission tool on our website: www.ethfellows.ethz.ch.

\section{SYNGENTA FOUNDATION}

\author{
WRO-1002.11.52, Postfach $\mathrm{CH}-4002$, Basel, Switzerland \\ Tel: (41) 613235634 \\ Fax: (41) 613237200 \\ Email: syngenta.foundation@syngenta.com \\ Website: www.syngentafoundation.com \\ Contact: Grants Enquiries
}

\section{Syngenta Foundation Awards}

Subjects: All subjects.

Eligibility: Open to candidates from African nations.

Type: Award

Value: Varies

Country of Study: Developing countries

No. of awards offered: Variable year to year

Application Procedure: Open.

Additional Information: The Syngenta Foundation does not have a formal award mechanism. It awards people within the projects in developing countries on an ad hoc basis

For further information contact:

Syngenta Foundation, Schwarzwalpallee 215, Bases, Switzerland, 4002

\section{SYRACUSE UNIVERSITY}

\author{
900 South Crouse Ave, Syracuse, NY, 13244, \\ United States of America \\ Tel: (1) 3154431870 \\ Fax: (1) 3154433423 \\ Email: grad@syr.edu \\ Website: www.syr.edu
}

Syracuse University is a non-profit, private student research university. Its mission is to promote learning through teaching, research, scholarship, creative accomplishment and service.

\section{African American Studies Graduate Fellowships}

Subjects: Any subject.

Purpose: To support new continuing graduate students across disciplines whose work supports that of the African American/Pan African studies program and who will make an intellectual contribution to the life of the Department of African American studies.

Eligibility: Open to African American fellows enrolled in at least one three-credit graduate course each semester in the African American Studies program for the duration of their award.

Level of Study: Doctorate, Postgraduate

Type: Fellowship

Value: $\$ 13,040$ for master's students, $\$ 21,805$ for doctoral students. Please check website www.syr.edu/gradschool/em/future fundingoptions.html

Frequency: Annual

No. of awards offered: 6

Application Procedure: Applicants must send their application along with a letter of intent and should indicate interest in this award.

Closing Date: January 1st

\section{Hursky Fellowship}

Subjects: Ukrainian language and literature, linguistics and culture. Purpose: To a full-time graduate student of Ukranian background enroled for the study of Ukrainian language and literature, Ukrainian linguistics and, culture.

Eligibility: Open to graduate students with a Ukrainian background enroled in Maxwell School of Citizenship and Public Affairs or the

College of Arts and Sciences, or any SU graduate whose area of study is the Ukraine or included Ukrainian topics.

Type: Fellowship

Value: stipend of $\$ 13,040$ and a tuition scholarship for 24 credits for the academic year and the following summer

Frequency: Annual

Closing Date: January 1st

\section{McNair Scholars Program}

Purpose: To increase the number of low-income, first-generation and underrepresented minority college students who pursue and complete the doctoral degree.

Eligibility: Open to the candidates who were McNair Scholars at their undergraduate institutions.

Level of Study: Postgraduate, Doctorate

Type: Fellowship

Value: $\$ 13,040$ for master's students, $\$ 21,805$ for doctoral students Frequency: Annual

No. of awards offered: 6

Closing Date: January 1st

\section{STEM Doctoral Fellowship}

Subjects: Science, technology, engineering and maths disciplines.

Purpose: To support doctoral students in the field of science,

technology, engineering and maths from underrepresented group of U.S. or its permanent residents.

Eligibility: Open to members of an underrepresented group who are U.S. citizens or permanent residents.

Level of Study: Doctorate

Value: US $\$ 20,150$ plus tuition scholarship

Frequency: Annual

No. of awards offered: 5

Closing Date: January 1st

Additional Information: Please refer to the website for more details: http://graduateadmissions.syr.edu/funding/fellowships/

\section{Syracuse University Graduate Fellowship}

Subjects: All subjects.

Purpose: To provide a full support package during a student's term of study.

Eligibility: Open to nationals of any country.

Level of Study: Unrestricted

Type: Fellowship

Value: US $\$ 13,040$ stipend for Master, US $\$ 21,805$ stipend for PhD

plus tuition scholarship

Length of Study: $1-6$ years

Frequency: Annual

Study Establishment: Syracuse University

Country of Study: United States of America

No. of awards offered: Varies by school/college

Application Procedure: Applicants must apply through admission application.

Closing Date: January 1 st

Funding: Private

Contributor: The Syracuse University Graduate School

No. of awards given last year: Varies

No. of applicants last year: 250 